\title{
Trpimir Vedriš
}

Odsjek za povijest Filozofskog fakulteta Sveučilišta u Zagrebu

Ivana Lučića 3, HR-10000 Zagreb

tvedris@ffzg.hr

\section{Histria i Hister kasnoantičlkih i ranosrednjovjekovnih geografa: prilog raspravi o spomenu Istre i Dalmacije u zemljopisu Alfreda Velikoga"}

\author{
Izvorni znanstveni rad | Original scientific paper \\ UDK 94(497.5-3 Istra):81'373.21>«08« \\ Primljeno: 6. II. 2012.
}

\begin{abstract}
Izvadak
Upozorivši na relevantnost ranosrednjovjekovne Geografije pripisivane anglosaskom kralju Alfredu Velikom kao izvora za hrvatsku povijest Mirjana Matijević Sokol i Vladimir Sokol potaknuli su raspravu o tumačenju značenja pojma Istria u tome spisu. Naglašavajući ulogu "milenijskih zabuna" klasičnih autora koji su povezivali Istru (Istria) s Dunavom (Ister) te inzistirajući na nužnosti shvaćanja "stvarne situacije" nastale raspadom klasične geografske vizije u ranosrednjovjekovnom kontekstu, u raspravi koja je uslijedila odbacili su veći dio primjedbi koje je na račun njihova tumačenja u međuvremenu uputio Radoslav Katičić. $\mathrm{Na}$ tragu te rasprave, autor u ovome tekstu razmatra problem odnosa pojmova Istriai Ister kod odabranih antičkih i ranosrednjovjekovnih autora nastojeći odgonetnuti što je zemljopisni pojam Istria mogao značiti u doba nastanka Alfredove geografije.
\end{abstract}

\footnotetext{
Prvotna inačica članka obranjena je kao veći kvalifikacijski rad na poslijediplomskom doktorskom studiju povijesti na Filozofskom fakultetu Sveučilišta u Zagrebu u ožujku 2008. Osnovne sam argumente u sažetom obliku izložio na skupu Stjepan Gunjača $i$ hrvatska srednjovjekovna arheološko-povijesna baština (Znanstveni skup povodom 100. obljetnice rođenja akademika Stjepana Gunjače, Muzej hrvatskih arheoloških spomenika, Split, 3. - 6. studenoga 2009.). Naknadno istraživanje uvelike mi je olakšala potpora istraživačke stipendije Mađarske komisije za stipendije Instituta Balassi (Hungarian Scholarship Board, Balassi Institute) za postdoktorsko usavršavanje u akad. god. 2011./2012. Zahvalan sam kolegicama i kolegama koji su tekst u međuvremenu pročitali upozorivši me na brojne nedostatake i pomažući mi da tekst popravim. Dvojica anonimnih recenzenata upozorili su me na niz novijih izdanja izvora te više relevantnih tekstova koje sam, uz iskrenu zahvalnost, nastojao u što većem broju uvrstiti u završnu verziju ovoga teksta. Konačno, uza sve dobronamjerne i konstruktivne primjedbe koje sam primio, tekst članka u mnogočemu ostaje nesavršen za što je, dakako, odgovoran - bilo iz tvrdoglavosti ili slabosti propusta - isključivo autor.
} 


\begin{abstract}
Sintesi
Segnalando la rilevanza della Geografia altomedievale attribuita al re anglosassone Alfredo il Grande in qualità di fonte per la storia croata, Mirjana Matijević Sokol e Vladimir Sokol hanno iniziato una discussione sull'interpretazione del significato del termine di Istria in tale scritto. Accentuando il ruolo delle "equivoci millenari" degli autori classici che collegavano l'Istria (Istria) con il Danubio (Ister) e insistendo sulla necessità della comprensione della "situazione reale" creatasi con il disfacimento della visione geografica classica nel contesto altomedievale, nella discussione che seguì sono riusciti a respingere la maggior parte delle obiezioni mosse nel frattempo da Radoslav Katičić contro la loro interpretazione. Sulle tracce di tale discussione, l'autore del testo prende in esame il problema del rapporto tra i termini di Istria e Ister negli autori antichi ed altomedievali da lui scelti, cercando di cogliere cosa avrebbe potuto significare il termine geografico Istria nel momento della stesura della Geografia di Alfredo.
\end{abstract}

Ključne riječi: Alfred Veliki, Istra, Ister (Dunav), rani srednji vijek, geografija, mappa mundi

Parole chiave: Alfredo il Grande, Istria, Ister (Danubio), alto medioevo, geografia, mappa mundi

\title{
1. "Ond be norđan Dalmatia sindon Pulgare ond Istria..."
}

Postavljajući pitanje "o prostoru kojim je vladao [knez Branimir], kakav je on bio, koliko je velik bio, i napokon, gdje se nalazio"1 Mirjana Matijević Sokol i Vladimir Sokol obnovili su zanimanje za, u hrvatskoj historiografiji, slabo korišten ranosrednjovjekovni izvor. Tzv. Geografija pripisivana anglosaskome kralju Alfredu Velikom (871. - 899.) ili nekome od učenjaka iz njegova dvorskoga kruga bila je poznata našim starijim povjesničarima, ${ }^{2}$ no relevantni ulomci na koje su upozorili Sokolovi bili su nezamijećeni više od jednoga stoljeća. Tekst koji nazivamo Alfredovom geografijom (dalje: AG) ${ }^{3}$ jest staroengleska redakcija djela Historiarum aduersum paganos libri VII Pavla

1 Mirjana Matijević Sokol - Vladimir Sokol, Hrvatska i Nin u doba kneza Branimira, Zagreb - Milano ${ }^{1} 1999$. (dalje: Matijević Sokol - Sokol, Hrvatska i Nin I).

2 Na Alfredovu Geografiju upozorio je Franjo Rački, "Biela Hrvatska i biela Srbija”, Rad JAZU, 52, 1880. 154-157, baveći se s "Hrvatih i Srbih u onih sjevernih predjelih". Analizirao je odlomak koji govori o "Horitima" koji žive "istočno od Daleminaca", no odlomak koji govori o Dalmaciji očito nije privukao njegovu pažnju.

3 Alfredovo autorstvo u novije je vrijeme odbačeno (npr. Janet Bately, "King Alfred and the Old English Translation of Orosius”, Anglia, 88, 1970., 433-460), stoga ću se, zadržavajući ponegdje njegovo ime iz stilskih razloga, referirati na "sastavljača" odnosno "autora AG". Starija, iako još uvijek navođena izdanja, su: King Alfred's Anglo-Saxon Version of The Compendious History of the World by Orosius, ed. Joseph Bosworth, London 1859.; Reinhold Pauli, The life of Alfred the Great; to which is appended Alfred's AngloSaxon version of Orosius, London 1857.; King Alfreds Orosius, ed. Henry Sweet, London 1883. Najnovije izdanje AG priredila je Janet Bately, The Old English Orosius (dalje: Bately, Old English Orosius), London - New York - Toronto 1980. 
Orozija (o. 375. - nakon 418.), zamišljenoga kao dodatak Augustinovoj De civitate Dei. Zbog ovisnosti o predlošku velik dio istraživača AG čak naziva “staroengleskim Orozijem”. Međutim, ostavljajući zasad po strani Orozijev izvornik (dalje: OR), valja podsjetiti da su Sokolovi, upozoravajući da se radi o jednom od rijetkih izvora suvremenih vladavini kneza Branimira (879. - 892.), zaključili da se radi o "vjerojatno najvažnijem izvoru” za hrvatsku povijest 9. st. "Tim riječima ponešto ipak prenaglašavajući značenje AG-a, Sokolovi su upozorili na spomen Hrvatske, "ali pod svojim antičkim imenom Dalmacije, te pod njezinim imenom i dijelova Panonije”. Ključni su odlomak objavili u svojem "slobodnijem prijevodu" koji glasi:

\begin{abstract}
"Na zapad od Ahaje (Peloponeza) koja se prostire do Sredozemnog mora nalazi se Dalmacija (Hrvatska), koja leži sjeverno od njega, a na sjever od Dalmacije (Hrvatske) jesu Bugari i Ister (Dunav). Južno od Istera (Dunava) onaj je dio Sredozemnog mora koji se naziva Jadransko, zapadno su Alpe, a sjeverno (od Hrvatske) puste su zemlje koje se nalaze između Karintije i Bugarske...”6
\end{abstract}

Usporedivši svoj prijevod s podatcima iz drugih relevantnih izvora, autori su, nadalje, došli do “čvrstog zaključka” da se "područje vladanja kneza Branimira” protezalo "od Dalmacije na sjever do Bugara i Dunava te (do Drave i) puste zemlje". ' Ovakvo je razumijevanje odlomka AG-a štoviše navelo autore i na zaključak da se u razdoblju kasnog 9. st. može govoriti o "učvršćenoj i dugoročno stabilnoj Hrvatskoj od Primorja do Slavonije i preko Braslava do Blatnograda”. ${ }^{\circ}$

Čini se da je, među ostalim, upravo inzistiranje na tome da je Dalmacija-Hrvatska obuhvaćala i "dio Panonije” (tj. međurječje Save i Drave kao što sugerira priloženi zemljovid), ponukalo Radoslava Katičića da temeljito prouči razmatrani odlomak AG-a i kritički se osvrne na rad Sokolovih. ${ }^{9}$ Očit doprinos Katičićeva osvrta jest ponajprije u tome što je raščlanjeni odlomak preveo prema izvornome staroengleskom tekstu (donesenom prema recentnom izdanju AG) čime je rasprava uvelike obogaćena autorovim jeziko-

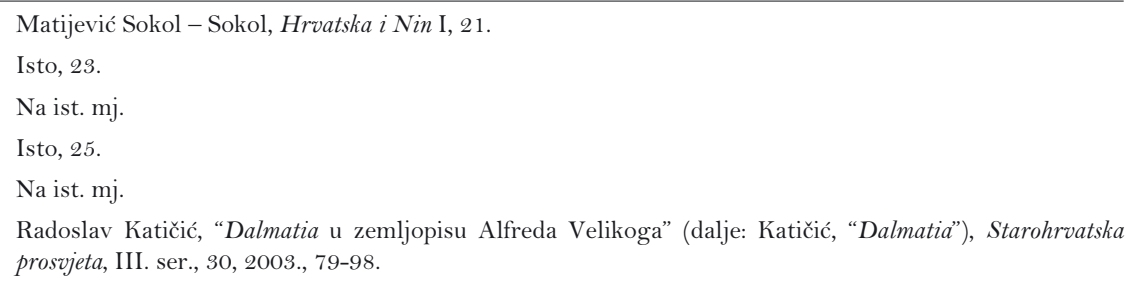


slovnim vještačenjem. Razmatrani ulomak "Alfredova teksta” u izvorniku, naime, glasi:

Ond be westan Achie andlang pas Wendelses, is Dalmatia pet land, on nordhealfe paes sas; ond be nordan Dalmatia sindon Pulgare ond Istria. Ond be sudan Istria is se Wendelsa pe man hat Atriaticum; ond be westan pa beorgas pa man Alpis; ond be nordan pat westen pat is betux Carendan on $[P]$ ulgarum..$^{10}$

Odnosno, u prijevodu R. Katičića:

"I na zapad od Ahaje uz Sredozemno more je zemlja Dalmacija, na sjevernoj strani tog mora, i na sjever od Dalmacije jesu Bugari i Istra, i na jug od Istre je ono Sredozemno more koje se zove Jadran, na zapad je ono gorje koje se zove Alpe, i na sjever je ona pustoš koja je između Karantanije i Bugara."11

Obogativši raspravu objavljivanjem staroengleskoga izvornika, Katičić je upozorio i na činjenicu da je bugarski prijevod razmatranoga ulomka, na koji su se Sokolovi očito bili oslonili, krajnje problematičan. Naime, i autor toga prijevoda Petar Koledarov svoj je prijevod oslonio na stariji prijevod drugoga bugarskog povjesničara Vasila Gjuzeleva te je, prema Katičiću, čitav niz pogrešaka u tom lancu pridonio tomu da je prijevod koji su ponudili Sokolovi ispao manjkav. ${ }^{12}$

Priznajući Sokolovima da su svojim prilogom "u hrvatskoj medievistici stekli trajnu zaslugu”, Katičić je prihvatio njihov zaključak da je termin Dalmacija u 9. st. mogao biti upotrebljavan (iako ne isključivo i jednoznačno) za “zemlju Hrvata pod vlašću njihova kneza”. Pretpostavku o tome da je Dalmatia, odnosno Hrvatska kneževina, graničila s Bugarskom Katičić je također ocijenio "dobro utemeljenom"13. Sažimajući pak njegove primjedbe može se reći da je, osim “preuzetnosti” u pogledu određivanja sjevernih granica Hrvatske kneževine, Katičić Sokolovima prije svega predbacio pogrešno tumačenje pojma Istria koji su oni, na tragu klasične geografije, protumačili kao da označava Dunav. ${ }^{14}$ Pretvarajući spomenuti Koledarovljev prijevod

\footnotetext{
10 AG I, i, 13-18 (Bately, Old English Orosius, 18).

11 Katičić, "Dalmatia", 82-83.

12 Isto, 88-90.

13 Isto, 90-91.

14 Matijević Sokol - Sokol, Hrvatska i Nin I, 23.
} 
pojma "Istrija” (Истрия) u "Ister" Sokolovi su, u strogo jezičnom smislu, pogriješili. Naime i Koledarov i Gjuzelev su prije njih ispravno (usprkos drugih pogrešaka) pojam Istria prenijeli kao Истрия, ne dajući povoda da se ime pokrajine prevede imenom rijeke. ${ }^{15}$

Inzistirajući upravo na neopravdanosti toga "pomaka u prijevodu", Katičić se usprotivio poistovjećivanju Alfredova izraza Istria s Dunavom te je, propitujući ponuđene argumente, zaključio da "nije moguće pozivati se na Konstantina Porfirogeneta ili na ikojeg drugog pisca kako bi se dokazivalo što zemljopisno ime Istria znači u Alfreda Velikog”. ${ }^{6}$ Time je Katičić odbacio svaku mogućnost da je sastavljač AG-a, spominjući Istru, na umu imao Dunav. Svoje je mišljenje utemeljio prvenstveno na tumačenju odnosa između AG-a i njegova kasnoantičkoga predloška OR-a, upozorivši pri tome na niz problema poput "nesklapnosti orijentacije prema stranama svijeta” te poremećenosti percepcije "višeslojnošću vrela iz kojih crpi podatke za svoj opis jadranskih predjela"17. Osvrt na podrijetlo percepcije Istre kao ravnopravne veličine naprema Dalmaciji Katičić je zaokružio ponovivši da se "Dunav u vezi s opisom Dalmacije uopće ne spominje” te da se, shodno tome, "ne valja pozivati na nj". ${ }^{18}$ Iznesena je argumentacija razložna i velikim dijelom uvjerljiva, kao i uostalom iz nje proizlazeći logičan zaključak.

Međutim, držeći da je za tumačenje AG-a "mjerodavan samo kontekst njegova opisa i, dakako, uporaba toga imena u zemljopisu njegova predloška Orozija"19, Katičić je u jednom segmentu, čini se, ipak donekle neopravdano kritizirao argumente Sokolovih. Naime, nasuprot iznesenom mišljenju, čini se da kontekst uporabe zemljopisnoga pojmovlja preuzetoga iz kasnoantičkoga predloška u AG-u, ipak dopušta pretpostaviti da nije isključivo OR mjerodavan kao predložak AG-a. ${ }^{20}$ Štoviše, čini se da je i Orozijeva uporaba geografskoga nazivlja, odnosno način na koji su ga upotrebljavali neki od njegovih nastavljača, tu i tamo nejasna, što je moglo dopustiti svakovrsna tumačenja. Ukratko, kao što proizlazi iz dosadašnjega tijeka rasprave, središnji je problem tumačenja relevantnosti odlomka AG-a za hrvatsku i istar-

15 Katičić, "Dalmatia”, 95.

16 Isto, 92.

17 Isto, 93.

18 Isto, 94 .

19 Isto, 92.

20 Usporedba "Alfredova opisa” s latinskim izvornikom jasno pokazuje da je autor AG-a u kasnoantičku geografiju uvrstio niz detalja koji odražavaju ranosrednjovjekovnu percepciju prostora dotad obilježenoga antičkim nazivljem. 
sku povijest ranoga srednjeg vijeka očito u razumijevanju pojma Istria. Ovo su jasno uočili i Sokolovi te su u drugom izdanju svoje knjižice neznatno promijenjenom tekstu pridodali i Dodatak u kojem su se osvrnuli na Katičićevo reagiranje. ${ }^{21}$ Time je središnje pitanje: "Je li Istria kod Alfreda Velikog Ister tj. Dunav ili poluotok Istra?” postavljeno s obnovljenom i donekle ojačanom argumentacijom. Oslanjajući se najprije na "milenijske zabune" klasičnih

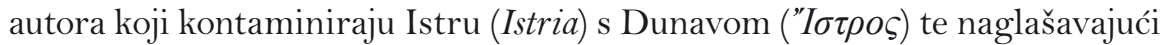
činjenicu da je u ranosrednjovjekovnom kontekstu nužno shvatiti "stvarnu situaciju” nastalu raspadom ujednačene klasične geografske paradigme, Sokolovi su odbacili velik dio Katičićevih primjedbi. ${ }^{22}$

Saževši time ukratko neke od problema uočenih u dosadašnjem propitivanju AG-a kao potencijalno vrlo dragocjenoga izvora za hrvatsku i istarsku ranosrednjovjekovnu povijest, želio bih se u ovome tekstu (ne želeći ulaziti u raspravu o širem problemu granica, tj. odnosa južnoga oboda panonskoga prostora i Hrvatske kneževine), usredotočiti ponajprije na tek prividno manje važan problem značenja i odnosa pojmova Dunav (Ister) i Istra (Istria) u AG-u i drugim, njemu suvremenim izvorima. ${ }^{23}$ Naime, koliko god obećavali zaključci o "kompatibilnim rezultatima različitih znanstvenih grana” i iznesene pretpostavke o opsegu Hrvatske kneževine krajem 9. st., zaključci i rezultati ovdje ukratko predstavljene diskusije ipak su vrlo daleko od sigurnih ili konačnih. ${ }^{24}$ Štoviše, može se reći da je značajan dio argumentacije - osobito glede korištenja izvora - metodološki bio postavljen na pomalo klimavim temeljima, što je pridonijelo tome da u dosadašnjoj raspravi na mnoga važna pitanja nisu ponuđeni zadovoljavajući odgovori. Dva temeljna problema, bez rješenja kojih bi svaka daljnja rasprava malo pridonijela stvarnome razrješavanju "Alfredove zagonetke", ponajprije su pitanje rukopisne tradicije AG-a (tj. pitanje što je “Alfred” zaista napisao) i pitanje predložaka AG-a (tj. pitanje što je "Alfred” mogao znati o opisanome prostoru). Kao što

21 Mirjana Matijević Sokol - Vladimir Sokol, Hrvatska i Nin u doba kneza Branimira, Zagreb ²005. (dalje: Matijević Sokol - Sokol, Hrvatska i Nin II), 25-34.

22 Isto, 26

23 Mišljenje da je "stavljati težište rasprave na relativno manje važan problem Dunava/Istera spram puno većeg problema Panonije i rane hrvatske države do Drave, zamjena problema” (Isto, 28) prihvatljivo je kao upozorenje o važnosti razumijevanja širega konteksta, no zaobilazeći (među ostalim i jezikoslovno) pitanje značenja određenoga pojma (dakako unutar povijesnog konteksta) nemoguće je riješiti problem.

24 U ovoj će raspravi pažnja biti usmjerena ponajprije tradiciji koja je utjecala, ili mogla utjecati, na oblikovanje AG-a. Izvori “domaće provenijencije”, poput Trpimirove darovnice, Povijesti salonitanskih prvosvećenika Tome Arhiđakona ili opisa Dalmacije u De administrando imperio, bit će temeljito razmotreni u nastavku ovoga članka u kojem namjeravam obraditi "stvarni sadržaj” AG-a i ponuditi tumačenje značenja toga spisa za hrvatsku povijest u 9. st. 
je često slučaj u bavljenju ranosrednjovjekovnim izvorima, ni na jedno od tih pitanja nije moguće sa sigurnošću odgovoriti. Nekoliko opažanja može ipak donekle suziti "prostor domišljanja” u daljnjoj raspravi.

Kao odgovor na prvo pitanje važno je naglasiti da su temelj svih dosadašnjih izdanja AG-a tek dva ranosrednjovjekovna rukopisa. ${ }^{25}$ Dosadašnja istraživanja tih rukopisa dopuštaju zaključiti da je danas dostupan tekst, barem što se relevantnih ulomaka tiče, onaj koji je krajem 9. st. zabilježio sastavljač AG-a. Tim bi opažanjem sumnja u "pouzdanost” tekstualne predaje trebala biti otklonjena. Drugo pitanje, ono o Alfredu dostupnim izvorima, vrlo je složeno i na njega je ovdje, dakako, nemoguće odgovoriti. Međutim, za daljnju bi raspravu bilo izuzetno važno, uz "unutarnje naznake" u samome tekstu, uzeti u obzir i rezultate opsežnih istraživanja o sastavu knjižnica i dostupnim djelima u ranosrednjovjekovnoj Engleskoj. ${ }^{26}$ Problemu starijih djela (a time i mogućih predložaka) dostupnih sastavljača AG-a bit će posvećeno nešto više pažnje.

Vraćajući se temeljnome pitanju “je li Istria u zemljopisu Alfreda Velikog Ister tj. Dunav ili poluotok Istra?”, iznijet ću najprije svoje polazne pretpostavke. Ponajprije, iako mišljenje da pojam Istria kod Alfreda označava Dunav (odnosno Podunavlje) ne smatram dokazanim, čini mi se da takvo tumačenje ne treba a priori odbaciti. Stoga ću u ovom izlaganju pokušati pokazati da je ipak moguće (djelomice nasuprot Katičićevim argumentima), štoviše nužno, pozvati se i na druge pisce da bi se, ako ne dokazivalo, no barem na drugačiji način pokušalo razumjeti što je zemljopisni pojam Istria mogao značiti za autora AG-a i njegove suvremenike. Pri tome ne namjeravam, dakako, tvrditi da za autora AG-a Istria nužno jest Dunav, no u svjetlu niza poznatih i manje korištenih izvora nastojat

25 J. Bosworth se u svojem izdanju (1859.) oslonio poglavito na tzv. MS Cotton (MS Cotton Tiberius B. i. datiranim u rano 11. st.; usp. Neil R. Ker, Catalogue of Manuscripts containing Anglo-Saxon, Oxford - New York ${ }^{2} 1990 .$, n. 191), kolacioniravši ga s tzv. Tollemachovim rukopisom (rukopis se u literaturi naziva i Lauderdale MS, datiran je u rano 10. st. i čuva se kao British Library Add. MS 47967; objavljen u pretisku: The Tollemache Orosius: British Museum additional manuscript 47967, ed. Alistair Campbell, Copenhagen 1953.), dok je H. Sweet (1883.) za svoje izdanje koristio Tollemache kolacioniravši ga s Cottonom. Manji dijelovi teksta sačuvani su i u drugim (kasnijim) rukopisima kao ulomci ili marginalne bilješke, no bez značaja za rekonstrukciju izvornog teksta. Janet Bately, "Alfred's 'Orosius' and 'Les Empereors de Rome”, Studies in Philology, 57/4, 1960., 567-568, bilj. 5.

26 Navodim tek nekoliko značajnih (meni dostupnih) naslova s ondje navedenom opsežnom literaturom i kazalima: Jack David Angus Ogilvy, Books known to the English, 597-1066, Cambridge (Mass.) 1967.; Michael Lapidge, "Surviving Booklists from Anglo-Saxon England", u: Learning and Literature in AngloSaxon England, ed. Michael Lapidge - Helmut Gneuss, Cambridge 1985., 33-89; Janet Bately, "Those books that are most necessary for all men to know'. The Classics and late ninth-century England: a reappraisal", u: The Classics in the Middle Ages, ed. Aldo S. Bernardo and Saul Levin, Binghamton 1990., 45-78; Michael Lapidge, The Anglo-Saxon Library, Oxford 2008. 
ću pokazati da je taj pojam kod pojedinih kasnoantičkih i ranosrednjovjekovnih geografa (uključujući i AG), osim sjevernojadranskoga poluotoka, barem načelno, mogao označavati i “porječje rijeke Ister”. S druge strane (djelomice nasuprot argumentima Sokolovih), ukazujući na nedostatnost građe korištene u dosadašnjoj raspravi da bi se Alfredova uporaba pojma Istria protumačila kao "drugo ime” za Dunav, nastojat ću pokazati zašto ne nalazim uvjerljivim tumačenje prema kojem AG dokazuje protezanje granica ranosrednjovjekovne Hrvatske kneževine do srednjega Podunavlja. Ne negirajući time per se opravdanost te pretpostavke, temeljito ću razmotriti dosad iznesene argumente uvjeren da potiču na daljnje istraživanje i otvaranje zanimljivih pitanja iz hrvatske i istarske povijesne geografije.

Oblikujući ovo izlaganje ponajprije kao pregled izvora i odraz stanja istraživanja s ciljem sastavljanja opsežnijeg teksta, nalazim prikladnim poći od propitivanja značenja koje pojmovima Istar i Istria pridaju stari grčki i latinski pisci. ${ }^{27}$ Predviđeni opseg rada ne dopušta temeljitiju raščlambu svih izvora relevantnih za ovu raspravu te ću, s obzirom na veliku količinu "kronološki razbacanoga” materijala, svjesno izbjeći pokušaj temeljitog osvrtanja na svu relevantnu historiografiju, nadajući se tek u naznakama upozoriti na mogućnost uklapanja iznesenih opažanja u postojeći historiografski kontekst. Pokažu li se na sljedećim stranicama iznesena opažanja neodrživima, nadam se da će upućivanje na neke od izvora i njihovo tumačenje obogatiti započetu raspravu - u najmanju ruku nizom dosad nerazmotrenih podataka.

\section{Podloga ranosrednjovjekovne percepcije: "I $\sigma \tau \rho o \varsigma$ i Danubius kod klasičnih autora ${ }^{28}$}

\section{1. Grčki autori}

Grci su Dunav, čini se, upoznali najkasnije tijekom 7. st. pr. Kr. kada se

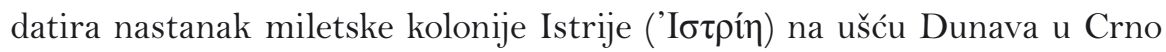

27 Velik dio tih tekstova dobro je poznat, štoviše, mnogi su od njih više puta prevođeni na hrvatski i razmatrani u kontekstu problematike srodne ovoj. Usp. Radoslav Katičić, "Podunavlje i Jadran u epu Apolonija Rođanina” i "Liburnski otoci kod antičkih pisaca” (oba članka navodim prema pretisku u knjizi Radoslav Katičić, Illyricum mythologicum [dalje: Katičić, Illyricum], Zagreb 1995.); Mate Križman, Antička svjedočanstva o Istri (dalje: Križman, Antička svjedočanstva), Pula ${ }^{2} 1997 . ;$ Vanna Vedaldi Iasbez, La Venetia Orientale e l'Histria. Le fonti letterarie greche e latine fino alla caduta dell'Impero Romano d'Occidente (dalje: Iasbez, La Venetia), Roma 1994.; Barbara Zlobec, "Poročila antičnih geografov o severnem Jadranu", Zgodovinski časopis, 53/1, 1999., 11-32. itd.

28 Gdje god postoji hrvatski prijevod navest ću ga u tekstu te, naznačujući njegovo izdanje, u bilješci dodati izvornik. Prijevodi ulomaka koji nisu dostupni u hrvatskom prijevodu (ili barem nisam na njih naišao) djelo su autora teksta. 
more. Ime Istar ('I $\sigma \tau \rho \varsigma \varsigma)$ tračkoga je podrijetla i većina grčkih autora, sve do ranoga srednjeg vijeka, koristila se njime uglavnom kao imenom za donji tok, ili pak crnomorsko ušće Dunava. ${ }^{29}$ Zanemarujući ulomke najstarijih geografskih spoznaja iz homerskoga razdoblja, vremena okarakteriziranoga “nepostojanjem autora i djela”, među prvima koji su zabilježili podatke o Istru $^{30}$ obično se navode Hekatej iz Mileta (o. 560 - o. 480. pr. Kr.) u Obilasku zemlje te tragičar Eshil (o. 525. - 456.) u izgubljenoj drami o Prometeju. ${ }^{31}$

Među najstarijim pak pouzdanim autorima iz vremena "pravih historičara, geografa i etnografa" ${ }^{2}$ koji spominju Dunav, osobito je značajan Herodot (o. 484. - nakon 430.), koji je u drugom poglavlju svoje Povijesti zabilježio:

“...kako ja zaključujem na osnovi poznatoga i izvodim zaključke o nespoznatom, on [Nil] izvire iz iste udaljenosti kao i Istar. Rijeka Istar ima izvor u zemlji Kelta kod grada Pirene i teče tako da razdvaja Europu po sredini. [...] Protječući cijelom Europom, Istar utječe u Crno more, ondje gdje Istriju nastavaju naseljenici iz Mileta."33

Spominjući u opisu Dunava miletsku koloniju na Crnome moru, Herodotova je Povijest jedan od prvih poznatih izvora koji eksplicitno dovodi u

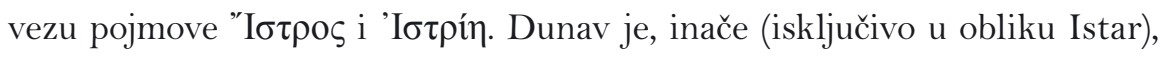
za Herodota česta referencija te ga više puta spominje. Uz općenita opažanja o značenju i veličini Dunava, najviše piše o njegovom donjem toku u četvrtoj knjizi opisujući sukob s Perzijancima. Izvan toga konteksta dvije mi se Herodotove opaske čine osobito značajnima za ovu raspravu. Pišući o zemljama sjeverno od Istra, Herodot je zabilježio:

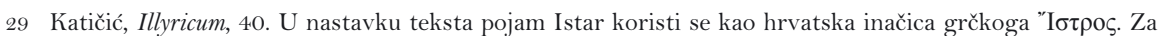
latiniziranu verziju (H)ister koristi se hrvatski Ister. Dunav se koristi u dva značenja: u užem smislu kao prijevod latiniziranoga keltskog imena Danuvius, u širem smislu kao danas uvriježeno ime te rijeke.

30 Najstariji zabilježeni spomen imena jest onaj u Heziodovoj Teogoniji. Vidi: Pomponius Mela, Chorographie (dalje: Pomponius, De Chorographia), ed. Alain Silberman, Paris 1988., 169, bilj. 10.

31 Mate Križman, "Istar", u: Istarska enciklopedija, ur. Robert Matijašić i Miroslav Bertoša, Zagreb 2005. Usp. i Katičić, Illyricum, passim. O Hekatejevu spomenu Istre usp. Križman, Antička svjedočanstva, 2833. Kritičko izdanje Hekatejeva teksta vidi u: Felix Jacoby (ed.), Die Fragmente der griechischen Historiker (FGrH), vol. 1, Leiden 1923. (repr. 1954.), 7-47.

32 Katičić, Illyricum, 14.

33 Herodot, Povijest, prev. i prir. Dubravko Škiljan, Zagreb 2000., 169. Grčki tekst navodim prema: Hérodote, Histoires, vols. II, V, ed. Philippe-Ernest Legrand, Paris 1930.-1946. (repr. II: 1963.; V: 1968.). Hérodote,

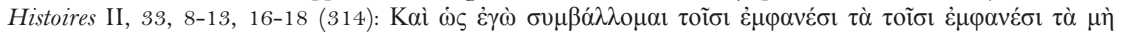

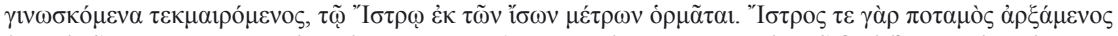

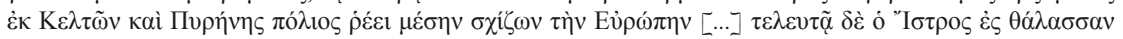

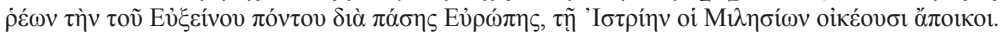


"Što se tiče sjevernog dijela ove zemlje, nitko ne može točno kazati koji ga narodi nastavaju, no očito je da je s onu stranu Istra zemlja pusta i beskonačna; jedini za koje sam uspio saznati da stanuju s onu stranu Istra su ljudi koji se nazivaju Siginjani, a oblače se poput Međana." ${ }^{4}$

te nešto niže nastavio da, "kako pričaju Tračani, s onu stranu Istra stanuju pčele, i zbog njih je nemoguće proći dalje” (dodajući da se njemu to s pčelama, doduše, ne čini istinitim zbog hladnoće). ${ }^{35}$ Oba navoda potvrđuju percepciju prekodunavskih krajeva kao puste divljine. Takva "slika" vrlo je rasprostranjen motiv koji će se često javljati i kod mlađih autora te s vremenom prerasti gotovo u opće mjesto "simboličke geografije” panonskoga prostora.

U tradiciji prirodoznanstvenoga proučavanja Dunava važno mjesto zauzimaju Aristotelovi (384. - 322.) spisi, odnosno njemu pripisana djela. Vrlo značajan podatak o Dunavu i njegovoj vezi s Jadranskim morem jest

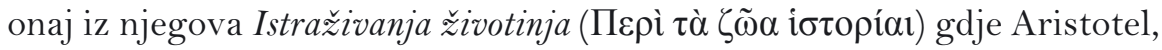
pišući o određenoj vrsti riba, spominje da samo "trikhije plivaju uzvodno Dunavom, pa gdje se ovaj cijepa, plivajući silaze u Jadran”. ${ }^{36}$ Aristotel spo-

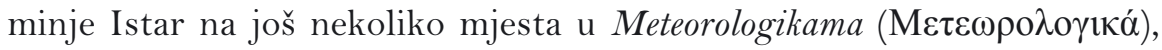
no uglavnom u općenitom smislu govoreći o njegovom geografskom položaju, veličini i značenju ${ }^{37}$ ili ponavljajući da je Istar, uz Nil, "među najvećim rijekama koje se ulijevaju u more”. ${ }^{38}$ Konačno o predodžbi da je Dunav povezan s Jadranskim morem eksplicitno piše i nepoznati autor spisa poznatoga pod imenom $O$ čudnim glasinama (Пepì $\theta \alpha v \mu \alpha \sigma i ́ \omega v$

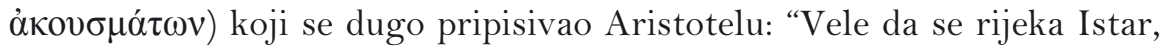
koja teče iz šume zvane Hercinijska, cijepa na dvoje te jednim dijelom

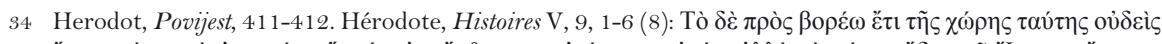

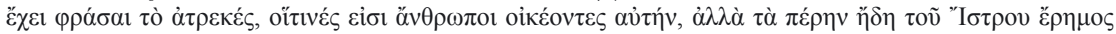

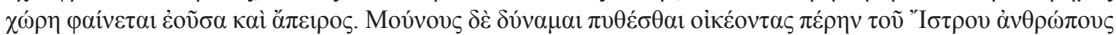

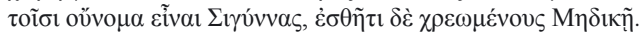

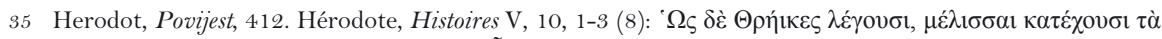

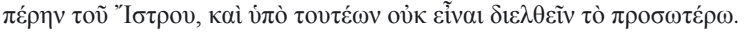

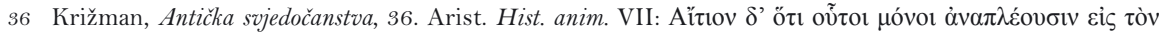

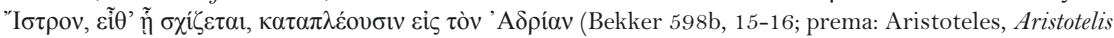
opera, ed. Immanuel Bekker, vol. 2, Berlin 1831. [repr. Berlin 1960.]), 144. Izraz "plivajući uzvodno"

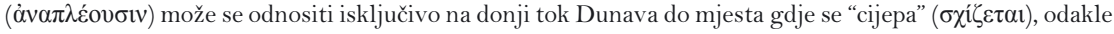

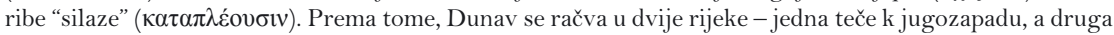
prema istoku. Širi kontekst navoda s komentrima u Križman, Antička svjedočanstva, 35-37.

37 Arist. Meteor., I, 13 (Bekker 350b 9-10), 96.

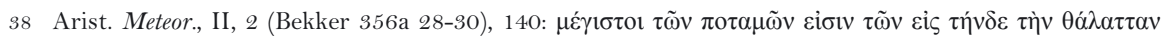
$\dot{\varepsilon} \xi$ lóv $\tau \omega v$. 
otječe u Crno more a drugim se ulijeva u Jadran.” (nastavljajući s dokazom da se onuda ne da ploviti). ${ }^{39}$

Posljednji se navod, s obzirom na to da mu nije moguće točno odrediti vrijeme nastanka (obično se datira između 3. st. pr. Kr. i 2. st.), ne može dakako uzeti kao suvremen Aristotelu ili njegovim direktnim nasljednicima. Međutim, pogrešno pripisivanje toga djela Aristotelu, kao i njegova djelomično "neznanstvena" narav ne umanjuju činjenicu da se to djelo "rado čitalo sve do kasne antike”, štoviše, da su se brojni etnografski i geografski podatci iz toga spisa "zbog omiljenosti te lektire bolje čuvali nego u izvornim i teškim djelima”" ${ }^{\prime \prime}$ Kakvo god bilo podrijetlo i sudbina Čudnih glasina, već na temelju prvoga od navedenih Aristotelovih ulomaka moguće je bez sumnje utvrditi postojanje, barem sredinom 4. st. pr. Kr., "znanstvenog geografskog znanja” prema kojem je Istar bio povezan sa sjevernim Jadranom. Štoviše, Aristotelovo mišljenje preuzela su kao autoritativno i dvojica velikih helenističkih znanstvenika, Eratosten (o. 276. - o. 195.) i Hiparh (o. 190. - o. 120.), o čemu svjedoče ulomci sačuvani kod Strabona. ${ }^{41}$

Uz navedene prirodoznance vjerojatno najznačajniji autor zahvaljujući kojem je predodžba o vezi dvaju mora dobila svoj čuveni književni oblik jest Apolonije Rođanin (3. st. pr. Kr.). Taj pisac zlatnoga doba Aleksandrijske knjižnice i helenističke učenosti jedini je među pjesnicima "aleksandrijskog kruga” sačuvao "svjedočanstvo" o putovanju Argonauta Dunavom od Crnoga mora do sjevernoga Jadrana. ${ }^{42}$ Njegov opis zagonetne "dunavske razdjelnice” glasi:
"A onda i uz goru Angur prođu i uz udaljenu
od gore Angur Kauliačku stijenu -
baš kod nje Dunav račva tok, te ovdje i ondje
uvire u more..." ${ }^{43}$

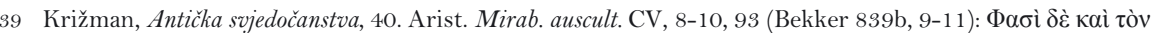

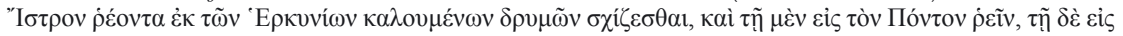
$\tau o ̀ v ~ ' A \delta \rho i ́ \alpha v ~ \varepsilon ̇ \kappa \beta \alpha ́ \lambda \lambda \lambda \varepsilon เ v$.

40 Katičić, Illyricum, 19.

41 Isto, 46. Usp. Strabonis geographica, 3 vols. (dalje: Strabo, Geographica), ed. Augustus Meineke, Leipzig 1877. (repr. 1969.), I, 3, 14ff; VII, 5, 9ff .

42 Detaljnije Katičić, Illyricum, 31-72, passim.; Križman, Antička svjedočanstva, 52-63. Apolonijevi suvremenici Likofron i Kalimah u svojim djelima Dunav gotovo i ne spominju. Usp. Križman, Antička svjedočanstva, $48-51$.

43 Križman, Antička svjedočanstva, 56. Apoll. Rhod. Argon. 4, 323-326: Aủiò

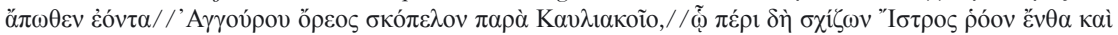

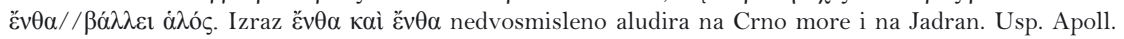
Rhod. Argon. 4, 284; 4, 302.
} 
Vezu između sjevernoga Jadrana (Istre) i Dunava (Istra) spominje zaista velik broj starijih grčkih autora, no za potrebe ove rasprave vjerojatno je dovoljno upozoriti na ovih nekoliko poznatijih. ${ }^{44}$

O podrijetlu geografske vizije prema kojoj je iz Crnoga mora moguće Dunavom ploviti do Jadrana dosta se raspravljalo. ${ }^{45}$ Aristotelova opaska, kao i legenda o povratku Argonauta, poput ostalih sličnih izvještaja, odražavaju arhajski sloj geografije prema kojoj su Grci, ne poznajući još sjeverne obale Crnoga mora, zamišljali da su se Argonauti mogli vratiti na Zapad po obodu Oceana, ili po nekoj od rijeka koje su spajale Ocean s Unutarnjim morem. ${ }^{46}$ Usprkos mitskom sloju koji je s vremenom bio sve češće kritiziran i na kraju odbačen, važno je naglasiti da ta slika vrlo dugo nije nestala, pa ni kada su proširene granice poznatoga svijeta i kada se spoznalo da nema direktnoga pristupa Oceanu iz Crnoga mora. Štoviše, ni ta "mitska slika” nije oblikovana bez oslonca u stvarnosti. Naime, "porječja velikih ruskih rijeka doista su kao trgovački putovi spajala Crno more sa sjevernim morima”, ${ }^{47}$ a ideju o plovidbi Oceanom zamijenila je ideja o plovidbi “dunavskim krakom”. ${ }^{4}$ Poput oslonca starije predaje na poznavanje sjevernih trgovačkih putova koji su povezivali Crno more sa Sjevernim, i novo je tumačenje počivalo na postojećim vezama između Crnoga mora i Jadrana. Stoga je s pravom Katičić ustvrdio da "zapadni tok Dunava nije drugo nego trgovački put koji je tekao Savom do sjevernog Jadrana”. ${ }^{49}$

Razmatrajući prethodna opažanja o vezi Crnoga mora i Jadrana, valja ukazati i na "zapadnu perspektivu” te pretpostavljene veze. Naime, osim razmotrene riječne poveznice, korijen drugoga vida "milenijske zabune”, očita "etimološka kontaminacija" poluotoka Istre i rijeke Istar, nalazi se vrlo rano kod brojnih autora. Tako se u Pseudo-Skilakovoj (390. - 330.

44 Uz navedene autore, vezu Istre i Istra navodi i Pseudo-Skimnova Periegeza (o. 110. pr. Kr.), Povijesna knjižnica Diodora Sicilskog (druga pol. 1. st. pr. Kr.) i dr. Usp. Križman, Antička svjedočanstva, 73-81, 109111.

45 Usp. Katičić, Illyricum, passim (s ondje navedenom literaturom).

46 Takovu verziju pripovijesti bilježe Hesiod, Pindar i dr. Katičić, Illyricum, 48.

47 Katičić, Illyricum, 45.

48 Nepoznati sholist uz Apolonijev tekst dodao je da "nitko ne priča o tome da su Argonauti po njemu uplovili u naše more osim Timageta za kim se poveo Apolonije”, što svjedoči o tome da pripovijest o "povratku Argonauta preko Dunava nije bila raširena verzija legende". Katičić, Illyricum, 49.

49 Katičić, Illyricum, 45. O stanju istraživanja krajnje točke tog riječnoga trgovačkog puta vidi: Ljubljanica: kulturna dediščina reke (dalje: Ljubljanica), ur. Peter Turk i dr., Ljubljana 2009., osobito Janka Istenič, "The Ljubljanica - a Roman trade and transportation route" (dalje: "The Ljubljanica”), 79-85; Marjeta Šašel Kos, "The Ljubljanica in ancient sources", 92-95 i dr. 
pr. Kr.) Oplovbi (Periplu) ${ }^{50}$ može pročitati da "iza Venetâ dolazi narod Istrâ, kao i rijeka Istar" ${ }^{51}$ te da "iza Istrâ dolazi narod Liburnâ." ${ }_{52}$ Pseudo-Skilakovo povezivanje naroda Istra i Dunava počiva na pretpostavci da su Istra i Crno more povezani te na mišljenju da oni nisu ni osobito udaljeni jedno od drugoga. Mišljenje o njihovoj blizini, tj. pretpostavka da se sa "središnjeg gorja mogu vidjeti oba mora”, 53 javlja se već kod Teopompa (4. st. pr. Kr.) i Pseudo-Skimna (2. st. pr. Kr.) te konačno i kod Strabona (64/63. pr. Kr. - o. 24.).

Daljnji korak u razvoju percepcije jadransko-crnomorske veze očit je

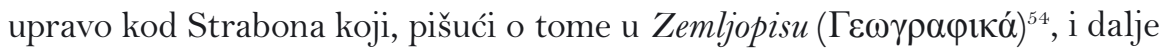
spominje vezu između dva riječna sliva, no ne smatra, poput svojih prethodnika, da Dunav utječe u Jadran. Za njega Dunav:

“...izvire u zapadnim predjelima Germanije, ali također i u blizini zaljeva Jadranskog mora (na udaljenosti od otprilike tisuću stadija od njega) i otječe u Pont ne daleko od izljeva Tira i Boristena.... ${ }^{{ }^{55}}$

Tim se opažanjem Strabon očito uvelike udaljio od starijega mitskog shvaćanja. Štoviše, približivši se "stvarnome zemljopisu" ${ }^{6}$, jedan od dva “izvora Dunava” smjestio je na "otprilike” nešto više od 150 kilometara od sjevernoga Jadrana. Strabonovih “tisuću stadija” izmjerenih kopnenim (pješačkim) putem gotovo se poklapa s otprilike stotinjak kilometara zračne linije koliko dijeli sjevernu jadransku obalu kod Trsta od izvora Save Bohinjke, odnosno nešto više od izvora Save Dolenjke, u današnjoj Sloveniji. ${ }^{57}$ Nadalje, Strabon na više mjesta eksplicitno odbacuje pogreške starijih

50 Usp. Mate Suić, “Istočna jadranska obala u Pseudo-Skilakovu Periplu”, Rad JAZU, 306, 1955., 121-185. Domaći su autori kao vrijeme nastanka često spominjali razdoblje između o. 390. i 330. pr. Kr. Prema novijim autorima nastanak Peripla datira se oko 330. pr. Kr. Usp. D. Graham J. Shipley, "Pseudo-Skylax on the Peloponnese", u: Dioskouroi, ed. Chrysanthi Gallou et al., Oxford 2008., 282-283.

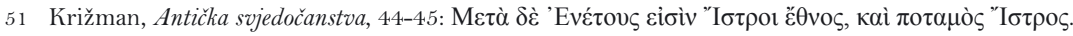

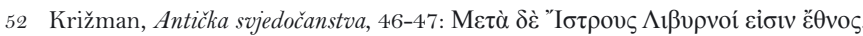

53 Katičić, Illyricum, 45, zaključuje da Pseudo-Skilak "spominje dunavsko ušće kod Istre" (usp. i Isto, 184187). Iako Pseudo-Skilak na tom mjestu to ne tvrdi eksplicitno, tumačenje je bez sumnje uvjerljivo.

54 O relevantim ulomcima Strabonova Zemljopisa vidi: Križman, Antička svjedočanstva, 88-103.

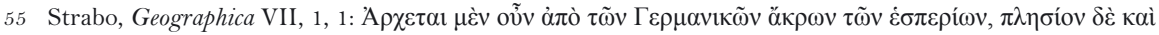

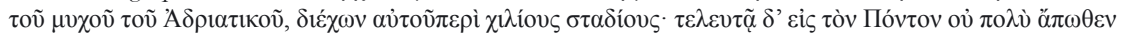

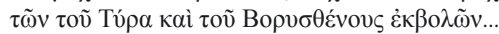

56 U kontekstu spominjanja uravnoteženih prikaza prostora Istre valja spomenuti i kasnije grčke autore poput Klaudija Ptolomeja (2. st.) i Kasija Diona (155. - 235.), koji u svojim spisima spominju Istru ostajući uvijek u granicama "stvarnog zemljopisa". O relevantim ulomcima vidi: Križman, Antička svjedočanstva, 120-133.

57 Izvorom Save mogao se smatrati i izvor Ljubljanice kraj Nauporta (Vrhnike), koju već Peutingerov zemljovid vjerojatno prikazuje kao Savu. Istenič, “The Ljubljanica”, u: Ljubljanica, 80-81. 
geografa. "Neznanje koje Hiparh dijeli s nekim od svojih prethodnika” za njega se sastoji se u time što su ti:

“...pretpostavili da ima neka rijeka, također zvana Istar, koja se od Istra odvaja i utječe u Jadran; po njoj da je nazvano pleme Istrâ, kroz kojih zemlju protječe, i njome da je Jazon doplovio iz Kolhide." 58

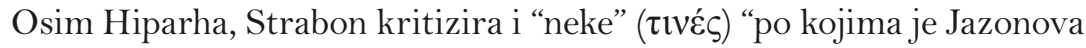
družina plovila čak do Jadrana”, pogrešno vjerujući da “rijeka Istar izvire iz Velikog Istra i da se izlijeva u Jadran", ${ }^{59}$ te Teopompa koji je, prema Strabonu, također vjerovao da se "rijeka Istar jednim od svojih ušća ulijeva u Jadran"60. Strabonov obračun sa "starïim, mitski ukorijenjenim, predodžbama o jadranskome prostoru, za koje u punom povijesnom svjetlu Strabonova doba više nije bilo mjesta", ${ }^{61}$ važno je iz perspektive ove rasprave smjestiti u kontekst (mogućega) utjecaja njegova spisa na kasnije autore. Naime, za razliku od npr. Plinijeva Prirodopisa, Strabonov je Zemljopis, iako sačuvan u cijelosti, u kasnoj antici na zapadu bio vrlo slabo poznat. ${ }^{62}$

Strabonov suvremenik Diodor Sicilski (djelovao o. 60. - 30. pr. Kr.) još je stroži od Strabona; oslanjajući se na "najsuvremenije spoznaje” zabilježio je da je:

“...samo vrijeme pobilo pretpostavku da Istar koji se na više ušća ulijeva u Crno more i Istar koji utječe u Jadran teku s istih mjesta. Jer, kad su Rimljani zavojštili na narod Histrâ, iznašlo se da ta rijeka izvire na četrdeset stadijâ od mora. Pisce je međutim, kako kažu, zavelo u bludnju to što se obje rijeke jednako zovu." ${ }^{\prime 3}$

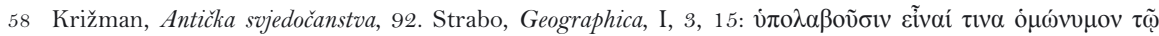

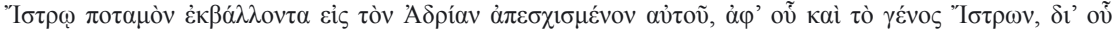

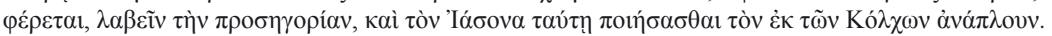

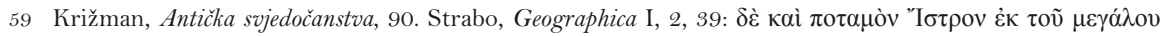

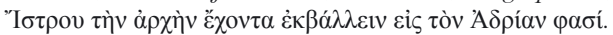

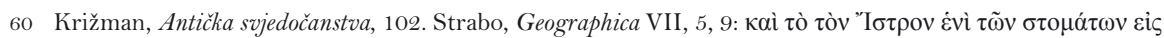

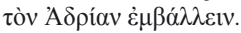

61 Križman, Antička svjedočanstva, 89.

62 Općenito uzevši, spis je privukao pažnju pisaca tek u 6. st., a češće ga navode tek bizantski autori od 9. st. Prema dosadašnjim istraživanjima, čini se da su rukopisi Strabonova djela dospjeli na zapad tek u 15. st. Prvi poznati prijevod na latinski naručio je papa Nikola V. (1447. - 1455.), a dovršen je oko 1458. Aubrey Diller - Paul Oskar Kriseller, Strabo, u: Catalogus Translationum et Commnetariorum: Medieval and Renaissance Latin Translations and Commentaries, vol. II (dalje: Catalogus II), ed. Paul Oskar Kristeller, Edward F. Cranz, Washington 1971., 225-226.

63 Križman, Antička svjedočanstva, 110-111; Diodorus Siculus, Library of History, vol. II (dalje: Diodorus, Bibliotheca historica), transl. Charles Henry Oldfather, LCL 303, Cambridge (Mass.) - London 1935., IV, 56,8 (524-526). 
U kontekstu rasprave o imenu rijeke Istar tj. Ister, zanimljivo je uočiti da Diodor spominjući imena dviju rijeka, implicira da se na području Istre neka rijeka također nazivala Istrom.

\section{2. Latinski autori}

Završivši sa Strabonom i Diodorom kratak pregled odabranih grčkih autora slijedi nam razmotriti na koji su način odnos Istre i Dunava, odnosno njihovih imena, percipirali njima suvremeni, a potom i mlađi latinski autori. Općenito uzevši, može se reći da je za latinsku geografiju karakterističan određeni "realistički odmak" od starije grčke tradicije. Rimski geografi, uvelike nezainteresirani za grčku sklonost matematičkoj geografiji (sa svim složenostima sustava zemljopisnih širina i dužina) promatrali su prostor prvenstveno pod praktičnim vidikom vojnih i administrativnih potreba. Što se Dunava tiče, može se reći da se "nije pravo znalo da su Istar i Danubius ista rijeka, kao ni gdje joj je izvorište, sve dok rimske legije nisu izbile u srednje Podunavlje." ${ }^{\prime 4}$ To se mišljenje obično potkrjepljuje činjenicom da je Dunav, pod njegovim izvorno keltskim imenom Danubius, prvi među latinskim autorima upotrijebio Gaj Julije Cezar (100. - 44. pr. Kr.) u Galskome ratu, zabilježivši da se Hircinijska šuma jednim dijelom "proteže uz Dunav" (quae fluminis Danubii regione pertinet...). ${ }^{65}$ Nešto je opsežniji u svojem opisu bio stotinjak godina poslije Kornelije Tacit (o. 55. - 116./120.), kada je u Germaniji zabilježio da je "cijela Germanija od Gala i Rećana, Panonaca odvojena rijekama Renom i Dunavom" te da "Dunav se izlijeva s lagano i blago izdignuta bila planine Abnobe, obilazi više naroda, dok se šestorim rukavcima ne probije u Pontsko more; sedmo se ušće gubi u močvarama" ${ }^{\prime 66}$. Tijekom stoljeća koje dijeli Tacita od Cezara više je latinskih autora spominjalo Dunav dijeleći njegov gornji tok pod imenom Dunav od donjega toka - Istra. ${ }^{67}$ Štoviše, neki su čak smatrali da se radi o dvjema rijekama. ${ }^{68}$

Među rane latinske geografije koje spominju Dunav isključivo pod

64 Križman, "Istar". Prema postojećim spoznajama, "tek je za Tiberija, 16. pr. Kr. upućen odred rimskih vojnika da konačno utvrdi gdje je mu je izvor”. Križman, Antička svjedočanstva, 245.

65 Caesar, Commentarii belli Gallici, ed. Wolfgang Hering, Leipzig 1997., VI, 25, 2 (100).

66 Kornelije Tacit, Manja djela. Historije, prev. Josip Miklić, Zagreb 2007., 127-128. Tacitus, De origine et situ Germanorum liber, u: P. Cornelii Taciti libri qui supersunt, tom. II, fasc. 2., ed. Alf Önnerfors, Bibliotheca scriptorum Graecorum et Romanorum Teubneriana, Stuttgart 1983., I, 1 (1): Germania omnis a Gallis Raetisque et Pannoniis Rheno et Danuvio fluminibus (...) separatur.; I, 2. (2) Danuvius molli et clementer edito montis Abnobae iugo effusus pluris populos adit, donec in Ponticum mare sex meatibus erumpat: septimum os paludibus hauritur.

67 Npr. Salustije, Aulo Gelije i Seneka (prema: Pomponius, De Chorographia, 169, bilj. 11).

68 Diodorus, Bibliotheca historica IV, 56, 7 (524-526). 
grčkim imenom Hister, spada i opis Agripina zemljovida, tzv. Agripini komentari. $^{69}$ Taj tekst, sačuvan u ulomcima kod kasnijih autora, spominje Dunav na nekoliko mjesta opisujući, čini se, isključivo njegov donji tok. ${ }^{70}$ Dva kraća kasnija teksta ovisna o Agripinim komentarima sačuvana su pod naslovima Dimensuratio provinciarum i Divisio orbis terrarum. ${ }^{71}$ Dimensuratio Dunav spominje tek na dva mjesta, u oba slučaja kao Hister. ${ }^{72}$ Opisujući krajnji sjeveroistok Italije, autor Divisio određuje granicu na Raši, no Istru imenom ne spominje. ${ }^{73}$ Nakon toga, navodi pokrajine istočno od Italije, i nadalje ispuštajući spomen Istre. ${ }^{74}$ Posljednji mi se ulomak čini zanimljivim po tome što, bez obzira na usku vezu s Agripinim komentarima, za razliku od svojega predloška, autor Divisio Dunav tu naziva Danubius, da bi ga u opisu Makedonije i Dacije spomenuo kao Hister. ${ }^{75}$

Među najstarijim latinskim autorima koji upotrebljavaju oba izraza jest Tit Livije (o. 59. pr. Kr. - 17.) koji je, očito se oslanjajući na starije autore, pišući o Prvom makedonskom ratu protiv Rimljana zabilježio zgodu u kojoj je Filip V. (238. pr. Kr. - 179. pr. Kr.):

“...obuzet željom da se popne na vrh gore Hem, jer je povjerovao pučkom (vulgo) vjerovanju da se otamo istovremeno mogu vidjeti Crno i Jadransko more, rijeka Dunav i Alpe, mislio da bi predočiti sva ta mjesta moglo biti od velike koristi za njegove planove o ratu protiv Rimljana.”76

69 Agripin (Marko Vipsanije Agripa, o. 64. - 12. pr. K.) zemljovid svijeta u Vipsanijevom trijemu spominje Plinije (Plinius, Naturalis historia, III, ii, 17).

70 M. Vipsanius Agrippa, Fragmenta, prema: Geographi Latini minores (dalje: GLM), rec. Alexander Riese, Heilbronnae 1878., 1-8, 14 (4): Ab Histri ostio ad os Ponti passuum D alii fecere; Agrippa LX adiecit.; 17 (4) Agrippa a Byzantio ad flumen Histrum DLX, inde Panticapaeum DCXXXV.; 18 (4) Agrippa totum eum tractum ab Histro ad oceanum bis ad decies centum milium passuum in longitudinem, quattuor milibus quadringentis in latitudinem.

71 Oba teksta navodim, prema GLM, kao Dimensuratio i Divisio. Vrijedno je opažanja da je tekst Divisio kasnije bio pripisivan sv. Jeronimu i vjerojatno poznat Alfredu (usp. Jerzy Linderski, "Alfred the Great and the Tradition of Ancient Geography" [dalje: Linderski, "Alfred the Great"], Speculum, 39/3, 1964., 438).

72 Dimensuratio 8 (10): a meridie flumine Histro; 11 (11): a septentrione flumine Histro. O Istri: Dimensuratio 15 (12): Pars Italiae ad Alpes finitur ab oriente ingis Alpium, ab occidente Histria et Caruia, a septentrione sinu Adriatico, a meridie mari Ligustico et Tyrrhenico (različiti rukopisi donose varijante: ystria, hystria, histria).

73 Divisio, 9 (16): Italia. Finitur ab oriente mari Ionio, ab occidente Alpibus et flumine Varo, a septentrione mari Adriatico et fumine Arsia, a meridie mari Tyrrenico.

74. Divisio 10 (16): Raetia maior, Noricus, Pannonia, Illyricum, Dalmatia, Liburnia. Finitur ab oriente Dardania, ab occidente Rheno, a septentrione flumine Danubio, a meridie mari Adriatico.

75 Divisio, 13-14 (17).

76 Livius, Ab Urbe condita XL, 21: cupido eum ceperat in uerticem Haemi montis ascendendi, quia uulgatae opinioni crediderat Ponticum simul et Hadriaticum mare et Histrum amnem et Alpes conspici posse: subiecta oculis ea haud parui sibi momenti futura ad cogitationem Romani belli. 
Inače, Livije i na drugim mjestima, pišući o donjem toku Dunava, rabi izraz Hister, kao u opisu Filipova djelovanja kada je on, vrativši se u Makedoniju, poslao svoje ljude da "pobune barbare koji žive uz Hister da napadnu Italiju.”77 Poput Livija, čini se da se već i njegov suvremenik Ovidije (43. pr. Kr. - o. 18.) koristi obama pojmima istoznačno. U svojim Tužaljkama (Tristia) Ovidije, naime, spominje "ušće Histra sa sedam usta (egressus septemplicis Histri)" te potom nabrajajući barbarske narode koje "Hister jedva zadržava” (quas non bene summouet Hister), u istome kontekstu spominje i "dubine Dunava” (Danuuii mediis aquis). ${ }^{78}$

Radi uočavanja mogućega kasnijega utjecaja Livijeva djela na srednjovjekovne autore, važno je naglasiti da je Ab Urbe condita, poput mnogih sličnih djela, bio rado čitan tijekom kasne antike, iako češće u sažetcima nego u cijelosti. ${ }^{79}$ Djelo je u izvornom obliku bilo vrlo slabo poznato ranosrednjovjekovnim autorima, ${ }^{80}$ no njegov ugled među intelektualcima iz Simahova kruga krajem 4. st. svjedoči o važnosti toga teksta u raspravi o rimskoj povijesti na vrhuncu procesa kristijanizacije rimskih elita. Stoga ne čudi obilata Orozijeva uporaba Livijeva djela. ${ }^{81}$

Lijep primjer rane rimske geografije (poč. 1. st.) u kojoj se pojmovi Dunav i Ister (već) isprepleću pruža Opis mjestâ (De chorographia) Pompo-

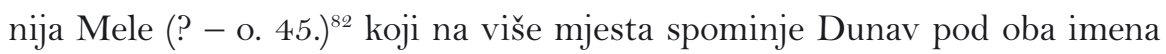
dovodeći ga, pritom, u vezu s Istrom. Spomen oba imena donosi najprije podsjećajući da per immania magnarum gentium diu Danuvius est, deinde aliter eum adpellantibus accolis fit Hister. ${ }^{83}$ Opisujući jadranske gradove, Mela ponovno spominje Dunav pod oba imena, dodajući zanimljiv podatak da per Histros Hister emittitur. ${ }^{84}$ Štoviše, čini se da Mela vjeruje da se Hister ulijeva u Jadransko more kraj istarske obale (ex adverso litore Histriae eodem impetu

77 Livius, Ab Urbe condita XXXIX, 35: (...) in Macedoniam rediit, missis ad accolas Histrifluminis barbaros, ut in Italiam irrumperent, sollicitandos.

78 Ovidius, Tristia, u: Bibliotheca Scriptorum Graecorum et Romanorum Teubneriana, ed. John Barrie Hall, Stuttgart - Leipzig 1995., II, 189, 197, 201.

79 Za povijest hrvatskih zemlja u antici Livijev je spis prije svega značajan zbog temeljitoga opisa histarskih ratova, o čemu vidi u: Križman, Antička svjedočanstva, 172-235.

80 Prvi poznati srednjovjekovni komentar $A b$ Urbe condita potječe tek iz ranoga 14. st., i to iz pera autora kojem, čini se, nisu bile poznate sve knjige. Alexander Hugh McDonald, Livius, u: Catalogus II, 331.

81 McDonald, Livius, 332.

82 Tekst navodim prema: Pomponius, De Chorographia.

83 Pomponius, De Chorographia II, 1, 8 (36).

84 Pomponius, De Chorographia II, 3, 57 (50): Vltra sunt Apollonia, Salona, Iader, Narona, Tragurium, sinus Polaticus et Pola, quondam a Colchis ut ferunt habitata, in quantum res transeunt! Nunc Romana colonia. Amnes autem Aeas et Nar et Danuvius qui iam dictus est Hister: sed Aeas secundum Apolloniam, Nar inter Piraeos et Liburnos, per Histros Hister emittitur. Tergeste intumo in sinu Hadriae situm finit Illyricum (!) (Danuvius spominje na još jednom mjestu u vezi s Rodanom [III, 3, 30 (75)]). 
profluens Hister amnis excipiat). ${ }^{85} \mathrm{Uz}$ navedena mjesta gdje govori o Dunavu, njegov Opis mjestâ donosi i spomen "Histrika” (Histrici) koji žive uz Dnjestar, a čije ime vjerojatno potječe od rijeke ${ }^{86}$ te spominje grad Histropol "u blizini obale Histra". ${ }^{87}$

Iz razmotrenih primjera proizlazi da su rimski autori 1. st., upoznavši Dunav prvenstveno preko osvajanja na sjeveru, keltsko ime Dunav (Danubius odn. Danuvius) izvorno upotrebljavali razlikujući gornji tok rijeke od donjega toka za koji su preuzeli grčki naziv latinizirajući ga kao Ister ili Hister. Međutim, iako više primjera potvrđuje takvu dvojnu uporabu, za ovu je raspravu važno naglasiti da takva podjela nikada nije bila apsolutna. Štoviše, već početkom 2. st. ustupila je mjesto simultanoj uporabi obaju pojmova za čitavu rijeku Dunav-Ister. Dunav je, u svakome slučaju, nakon osvajanja Panonije za Rimljane postao egzaktna, ali i simbolička granica spram barbarskih zemalja, obod koji je omeđivao široko shvaćen prostor Ilirika. U tom ga smislu među prvima spominje Gaj Svetonije Trankvil (o. 69. - posl. 130.) u Životopisu cara Tiberija zabilježivši da je Tiberije, ugušivši Batonov ustanak, "svladao i pokorio čitav Ilirik, koji se proteže između Italije, Norika, Trakije i Makedonije, te između Dunava i Jadranskog mora." ${ }^{8}$

Povezivanje Dunava i Dalmacije kod klasičnih rimskih autora najčešće je daleko od odlika kakve mitske ili iskrivljene geografije. Štoviše, često je riječ o sasvim pragmatičnom opisu Ilirika koji se određuje kao prostor koji povezuje Jadran s Dunavom. Takav Ilirik, "sretno upravljan u Augustovo” vrijeme, spominje i Josip Flavije u svojim Židovskim ratovima pitajući se: “Nisu li i Iliri, koji nastavaju zemlju koja se nalazi između Dalmacije i Dunava, upravljani tek s dvije legije?"89 Tako široko ocrtan rimski Ilirik postao je već tijekom 1. st. administrativno-geografski entitet koji je povezao jadransku obalu sa srednjim Podunavljem. Spomi-

85 Pomponius, De Chorographia II, 4, 63 (51). Inače, za Pomponija Hister izvire u blizini Rodana i Rena, protječući kroz Trakiju, u Crno more se ulijeva kroz šest ušća; II, 5, 79 (55): Rhodanus non longe ab Histri Rhenique fontibus surgit; II, 2,16 (38): His Thracia proxima est, (...) qua latera agit Histro pelagoque contingitur.; II, 7, 98 (60): Sex sunt inter Histri ostia. Hister se spominje i uz rijeku Vislu u III, 4, 33 (76).

86 Pomponius, De Chorographia II, 1, 7 (36): Hos ab Histricis Tyra separat.

87 Pomponius, De Chorographia II, 2, 22 (40): In litoribus Histro est proxima Histropolis.

88 Gaj Svetonije Trankvil, Dvanaest rimskih careva, prev. Stjepan Hosu, Zagreb 1978., 128. Suetonius, Vita Tiberii, u: Suetonius, De uita Caesarum, ed. Maximilianus Ihm, Leipzig 1908., XVI, 2 (120): Acperseuerantiae grande pretium tulit, toto Illyrico, quod inter Italiam regnumque Noricum et Thraciam et Macedoniam interque Danuuium flumen et sinum maris Hadriatici patet, perdomito et in dicionem redacto.

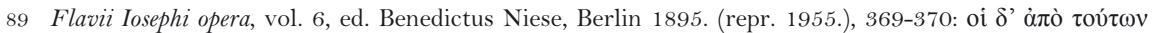

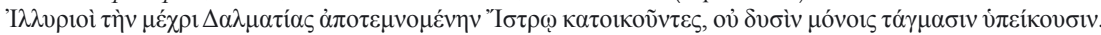


njan kao takav kod mnogih klasičnih pisaca, postat će uzorom i predloškom njihovim ranosrednjovjekovnim čitateljima. Za ovu raspravu to je značajno ponajprije u kontekstu percepcije Karla Velikog kao Augustova nasljednika, čime je ideja obnove Ilirika prilikom prodora u Panoniju mogla odigrati važnu ulogu u nadahnuću i opravdanju za franački prodor na Dunav, no isto tako imati značajna udjela u zemljopisnom viđenju toga prostora. ${ }^{90}$

Vraćajući se pitanju odnosa Dunava-Istra i Istre, može se reći da se kod latinskih pisaca nalazi manje starijega "mitološkog materijala” nego kod Grka. Već početkom 1. st. autori poput Plinija Starijeg (o. 23. - 79.) ${ }^{91}$ ili Pompeja Troga (poč. 1. st.) ${ }^{92}$ argumentirano ispravljaju pogreške starijih geografa. Tako Plinije u poznatom odlomku iz Prirodopisa piše:

“Ova (Istra) je, navodno, nazvana po rijeci Histru što se kao odvojak Dunava, koji se zove i Histar, ulijeva u Jadran nasuprot ušću Pada, te od sudara njihovih voda iz suprotnih smjerova more između njih gubi slanost: mnogi tako rekoše, i to krivo, pa i Nepot, žitelj s padskih obala: ni jedna rijeka ne istječe iz Dunava u Jadran. A mislim da ih je prevarilo to što je lađa Argo sišla u Jadransko more nedaleko od Trsta, no ne znam više kojom rijekom. Savjesniji pisci bilježe da su je preko Alpa prenijeli na ramenima, a da je dotle doplovila rijekom Histrom, zatim Savom, pa onda Nauportom, »lađonoscem«: odatle i ime toj rijeci što izvire između Emone i Alpa." 93

Općenito, opisujući na više mjesta prostor koji je predmet ovoga istraživanja, Plinije pokazuje vrlo dobru obaviještenost. Ovdje je zanimljivo tek uočiti da, kritizirajući “etimološku vezu” između Istre i Istra, Plinije doduše

90 Usp. Matijević Sokol - Sokol, Hrvatska i Nin II, 7.

91 Ulomci Plinijeva djela koji se na razne načine dotiču "istarske tematike" navedeni su s prijevodom i komentarima u: Križman, Antička svjedočanstva, 260-289. O Plinijevu opisu Ilirika vidi: Alka Domić Kunić, "Literarni izvori za iliričke provincije”, Vjesnik Arheološkog muzeja u Zagrebu, 37, 2004., 119-171.

92 O relevatnim ulomcima Trogova djela Historiae Philippicae, sačuvanom tek u sažetku Marka Junijana Justina, vidi: Križman, Antička svjedočanstva, 242-247.

93 Križman, Antička svjedočanstva, 266-269: Quam cognominatam a flumine Histro, in Hadriam effluente e Danuvio amne eodemque Histro exadversum Padi fauces, contrario eorum percussu mari interiecto dulcescente, plerique dixere falso, et Nepos etiam Padi accola; nullus enim ex Danuvio amnis in mare Hadriaticum effunditur. Deceptos credo, quoniam Argo navis flumine in mare Hadriaticum descendit non procul Tergeste, nec iam constat quo flumine. Umeris travectam Alpis diligentiores tradunt, subisse autem Histro, dein Savo, dein Nauporto, cui

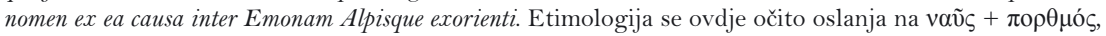
što je Rimljanima "moglo zvučati kao »lađonosac«" (Križman, Antička svjedočanstva, 269, bilj. 306). 
nastoji opovrgnuti prastaro uvjerenje o vezi Dunava i Jadrana, no time još, čini se, ne pobija postojanje "odvojka Histra" ${ }^{94}$

Ukratko, kad bi se razvoj geografskih spoznaja mogao promatrati pod prizmom kakvoga "pravocrtnog napretka”, moglo bi se u ovome kontekstu zaključiti da je već Strabon raspršio velik dio zabludâ, a Plinije do kraja pokopao mitsko viđenje veze između Crnoga mora i Jadrana. Međutim, očito je da starije predodžbe ni stoljećima nakon pisanja dvojice velikih prirodoslovaca nisu u potpunosti nestale. Naime, čak i nakon što su Rimljani "svojim osvajanjima doprli do Dunava, a ubrzo zatim prošarali čitavo to područje cestama, kolonijama i vojnim logorima" ${ }^{95}$, mnogi su autori, bilo da nisu poznavali Strabonove i Plinijeve radove, bilo da ih nisu razumjeli, ili, konačno, bilo da nisu željeli prihvatiti njihove zaključke - jednostavno nastavili ponavljati "stare zablude". ${ }^{96}$ Mogućnost "recidivističkoga” povratka na percepciju starijih slojeva geografskoga znanja moguće je osobito pratiti u razdobljima socijalnih i institucionalnih kriza, poput one povezane s dezintegracijom Rimskoga Carstva u kasnoj antici, kada su mnoga značajna djela klasičnih autora bila izgubljena i zaboravljena. Sudbina Plinijeva djela u tom je kontekstu jedinstvena; za razliku od mnogih suvremenika, nema stoljeća iz kojeg nije sačuvan spomen na njegov Prirodopis. ${ }^{97}$

Vraćajući se time, na tragu Katičićeva inzistiranja na različitoj uporabi pojmova Dunav i Ister kod rimskih autora, još jednom pitanju naziva za tu dvoimenu rijeku, želio bih ovdje upozoriti i na nekoliko primjera svjesnoga izjednačavanja imenâ Dunav i Ister kod ranih rimskih autora. Npr. Pomponije Mela (sred. 1. st.) u svojem Opisu mjestâ spominje i "Dunav što je nazvan i Istar", koji "utječe u zemlji Istrâ" (et Danubius qui iam dictus est Ister... per

94 Za razliku od Dunava-Istra, stanovnici Istre bili su Rimljanima poznati znatno ranije. Ratove s Histrima tijekom kasnog 3. i ranog 2. st. pr. Kr. (u historiografiji često konvencionalno klasificirane kao Prvi i Drugi histarski rat) opisalo je više latinskih autora (Apijan, Tit Livije, Dion Kasije, Orozije), no mahom se radi o znatno kasnijim preradama starijih podataka. O Istrima i istarskim ratovima u novijoj historiografiji vidi: Robert Matijašić, Povijest hrvatskih zemalja u antici do cara Dioklecijana, Zagreb 2009.; Alka Starac, Rimsko vladanje u Histriji i Liburniji: Društveno i pravno uređenje prema literarnoj, natpisnoj i arheološkoj gradi: I. Histrija, Pula 1999.

95 Križman, Antička svjedočanstva, 268, bilj. 303.

96 Ovdje valja naglasiti da za antičke autore nije bilo neobično paralelno se koristiti starijim i novijim, ponekad međusobno suprotstavljenim, mišljenjima. Usp. Greg Woolf, Tales of the Barbarians: Ethnography and Empire in the Roman West, Malden 2011. (osobito u poglavlju "Explaining barbarians", 32-58).

97 Plinijevo je djelo bilo (vrlo vjerojatno čak i u cijelosti) poznato mnogim kasnoantičkim autorima poput Euzebija, Sidonija Apolinara, Jeronima, Augustina. Charles G. Nauert, C. Plinius Secundus (dalje: Nauert, Plinius), u: Catalogus IV, 300. Štoviše, "usprkos napasti da ga se čita u skraćenim i pojednostavljenim kasnoantičkim izvadcima”, Plinijevo je djelo bilo poznato većem broju autora u ranosrednjovjekovnoj Engleskoj poput Aldhelma (639. - 709.) ili Bede Časnoga (673. - 735.); usp. Nauert, Plinius, 302-303. Zanimljivo je da je za rani srednji vijek poznavanje Plinija (rukopisima i navodima) bolje posvjedočeno na Britanskom otočju nego na europskom kontinentu. 
Istros Ister emittitur).$^{98}$ Osim što je Melin spomen Dunava zanimljivo svjedočanstvo preživljavanja starijih, "mitskih predodžbi”, ${ }^{99}$ s njime, čini se, počinje niz latinskih autora koji sasvim eksplicitno izjednačuju pojmove Dunav i Ister. Na tome su tragu i riječi nepoznatoga autora (pripisane Luciju Ampeliju) koji, nabrajajući značajne svjetske rijeke, navodi i "Dunav koji se naziva Ister, u Meziji” (Danubius, qui idem Ister cognominatur, in Moesia). ${ }^{100}$ Slično tome, u svojem Komentaru Vergilijevih Georgika, Mauro Servije Honorat u 4. st. nedvosmisleno potvrđuje dovršetak procesa izjednačavanja Istra i Dunava riječima: "Hister je rijeka u Skitiji, koja se naziva i Dunav" (Hister fluvius est Scythiae, qui et Danubius nominatur). ${ }^{101}$

Pregled klasičnih latinskih geografskih tekstova čini se prikladnim završiti spomenom Julija Honorija, slabo poznatoga geografa čije se djelovanje smješta u širok raspon 4. i 5. stoljeća. Iako se o autoru ne zna gotovo ništa, poznato je da su izvadci Honorijeva Opisa svijeta (Cosmographia) bili čitani na izmaku antike i u ranome srednjem vijeku. ${ }^{102} \mathrm{Za}$ ovu je raspravu zanimljivo da Honorije u svojim popisima zapadnih pokrajina Istru ne spominje, kao ni istarske gradove u popisu quae oppida in provinciis suis habet oceanus occidentalis. ${ }^{103} \mathrm{O}$ Dunavu (pod oba imena) piše Honorije na više mjesta $^{104}$ od kojih su osobito značajni popisi rijeka Oceani occidentalis. ${ }^{105} \mathrm{Tu}$ se može pročitati da Dunav (Danuvius/Danubius) izvire u Alpama te se dijeli u dvije rijeke (!) koje zaokružuju gradove Panonijâ da bi se spojili i otekli u Crno more. U istome se ulomku opisuje i Sava (Savus), koja također izvire u Alpama i, protječući kraj Siscije, Sirmija i Singiduna, uvire u Dunav. ${ }^{106}$ Prema najznačajnijem rukopisu Opisa, opis Save završava riječima: et ungit se Danuvio flumini. et omnes simul per crines supra dictos intrant Pontum. et vocatur

\footnotetext{
98 Križman, Antička svjedočanstva, 252-253.

99 Pomponius, De chorographia 2, 4 (prema Križman, Antička svjedočanstva, 254-257).

100 Liber memorialis, ed. Erwin Assmann, Leipzig 1935., VI, 8, 9 (10). Konkretan je ulomak, doduše, moguće razumjeti dvojako: kao da se "Dunav naziva Istrom u Meziji", ali i u skladu s opisom ostalih rijeka, kao da se "Dunav, koji se naziva i Ister, nalazi u Meziji".

101 Honoratus, Commentarii III, 349-350., prema: Servii Grammatici in Vergilii carmina commentarii, rec. Georgius Thilo et Hermannus Hagen, Leipzig 1881.

102 Kasiodor ga, kao autora značajnoga za "studij zemljopisa", u Institucijama navodi u društvu Ptolomeja, Komesa Marcelina, Dionizija Periegeta i Orozija. Prema: Natalia Lozovsky, The earth is our book: geographical knowledge in the Latin West ca. 400-1000 (dalje: Lozovsky, Earth), Ann Arbor 2000., 14-17. Tekst Opisa svijeta navodimo prema GLM, 24-55 (dalje: Honorius, Cosmographia).

103 Usp. Honorius, Cosmographia, A18/B1 (34); A 19/B11 (34-35).

104 Isto, A20/B1 (36).

105 Isto, A24/B 11 (38-40).

106 Isto, A24 (38-39).
} 
Hister. ${ }^{107}$ Iako se iz konteksta čini očitim da se Hister odnosi na Danuvio flumini, s obzirom na to da je odlomak posvećen Savi, čitatelj može ostati u nedoumici glede autorove nakane. Da je Honorijev nejasan izričaj imao utjecaja na kasniju recepciju toga prostora svjedoči mlađi spis poznat kao Opis svijeta (Aethici Histri Cosmographia), kao i više srednjovjekovnih zemljovida koji će biti razmotreni nešto poslije.

Završivši Julijem Honorijem pregled navoda “starijih” latinskih autora, moguće je konačno, još jednom, uočiti da oni, iako ponegdje uistinu terminološki razlikuju gornji i donji tok Dunava, ova dva imena vrlo rano izjednačuju. Neosporna jest činjenica da najstarïi grčki autori pišući o Istru

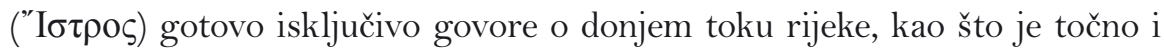
to da pojedini rimski pisci 1. st. spominjući Danubius prvenstveno misle na njegov gornji tok. Međutim, dva se imena za Dunav vrlo rano isprepleću i upotrebljavaju kao istoznačnice. Takva je uporaba, kao što je izloženo, karakteristična za većinu pisaca iz kasnoga carskog razdoblja. U tom smislu, ovdje odabrani i razmotreni tekstovi jasno svjedoče kako primjedba da "Ister nije isto što i Dunav" slabo vrijedi čak i kod većine klasičnih autora. Stoga, važno je naglasiti da, kao što su uočili Sokolovi, Katičićeva primjedba o Alfredovoj uporabi naziva za Dunav nije nužno održiva. ${ }^{108}$ Nije, naime, teško utvrditi da ne samo da Alfred, već i mnogi njemu suvremeni autori, oslanjajući se na neke od upravo razmotrenih starijih autora, oba naziva za Dunav rabe istoznačno. To je opažanje osobito značajno za nastavak izlaganja i raščlambu ulomaka iz djela odabranih kasnoantičkih i ranosrednjovjekovnih autora. Stoga ću, na tragu poticajnoga opažanja o nužnosti shvaćanja "stvarne situacije" i okolnosti oblikovanja ranosrednjovjekovnoga zemljopisnoga obzora, ${ }^{109}$ u sljedećem odjeljku razmotriti pitanje uporabe imenâ za Dunav te odnos pojmova Istra (Istria) i Ister (Ister) u vrelima iz razdoblja između početka 5. i kraja 9. st. ${ }^{110}$

\footnotetext{
107 Isto, A24 (39). Drugi rukopis na sličan način opisuje ušće Dunava upotrijebivši plural et vocantur smanjujući mogućnost pogrešnoga tumačenja.

108 Matijević Sokol - Sokol, Hrvatska i Nin II, 29.

$109 \mathrm{Na}$ ist. mj.

110 Popisu razmotrenih autora bilo bi prikladno dodati i Amijana Marcelina (o. 325./330. - poslije 391.) koji, premda ne piše "zemljopis", već "povijest", donosi veći broj za ovu raspravu relevantnih podataka. Naime, na temelju opažanja Maurizija Levaka, kome srdačno zahvaljujem na tim podatcima, Amijan izraz Ister (Hister) za Dunav, neovisno o kojem njegovom dijelu govori, rabi (u sačuvanom dijelu svoga djela) 16, a Dunav (Danubius) 7 puta. Pojam Istre (Histria) upotrebljava jednom, i to za jadranski poluotok. Bilo bi vrijedno razmotriti i rukopisnu tradiciju Amijanovih Res gestae čiji trag vodi, čini se, u 9. st. u Fuldu ili neki drugi od karolinških samostana poput Hersfelda.
} 


\section{Dvostruko ime za Dunav kod kasnoantičkih i ranosrednjovjekovnih autora}

\section{Pavao Orozije (o. 375. - nakon 418.)}

Orozijevu je zemljopisnu viziju ${ }^{111}$ širega hrvatskoga prostora temeljito i uspješno raščlanio R. Katičić, stoga nema potrebe detaljno ponavljati ondje iznesena opažanja. ${ }^{112}$ Međutim, s obzirom na važnost Orozijeva djela kao predloška (točnije, jednoga od predložaka) za AG, čini mi se ipak prikladnim razmotriti i nekoliko mjesta gdje Orozije piše o Dunavu izvan razmatranoga “dalmatinskog” ulomka. Ostavljajući zasad po strani dio teksta koji je poslužio kao neposredan predložak autoru AG-a, ${ }^{113}$ kao i već navedeno mjesto na kojem on podsjeća na postojanje dva imena za rijeku Dunav-Ister, ${ }^{114}$ može se pouzdano utvrditi da Orozije, poput svojih prethodnika, oba imena rabi s jednakim značenjem. Opisujući u drugoj knjizi svoje Povijesti rušenje mosta na Dunavu za Darijeva pohoda protiv Grka, Orozije rijeku naziva Istrom ${ }^{115}$ da bi, pripovijedajući u četvrtoj knjizi o makedonskim ratovima, ponovno dva puta spomenuo Ister naglasivši da je riječ o Dunavu. Pišući o uništenju Bastarna zabilježio je da je taj "vrlo divlji narod":

“potaknut po savjetu Filipova sina Perzeja nadom u obilat plijen i mogućnošću da prijeđe rijeku Ister, uništen bez ikakve borbe ili nekog neprijatelja. Naime, u to je vrijeme Dunav, koji se naziva i Istrom, bio pokriven čvrstim ledom i mogao se lako prijeći pješice.”116

Uz uočeno poistovjećivanje Dunava i Istra mnogo prije Orozijeva vremena, u kontekstu raščlambe njegova spisa, čini mi se važnim podsjetiti i na opažanje Sokolovih koji su, odgovarajući na Katičićeve primjedbe, upozorili na potencijalno vrlo važan detalj kod Alfredove uporabe pojmova Ister i Istria, naime, različitu grafiju kad piše o Istranima (Hisdriane) na donjem toku Dunava i Istranima (Isprie) u Istri. ${ }^{117}$ Bez obzira na konačan ishod uspo-

111 O Oroziju kao kasnoatičkom geografu vidi: Andrew H. Merrills, History and Geography in Late Antiquity, Cambridge 2005., 35-99 (dalje: Merrills, History).

112 Izbor ulomaka Orozijeva teksta s hrvatskim prijevodom i komentarima donosi Katičić, "Dalmatia”, 83-87.

113 Ulomke relevantne za opis smještaja Istre (OR I, 2, 55, 59-60) donosi i Križman, Antička svjedočanstva, 330-333.

114. OR I, 2 (PL 31, 686A): ...usque ad Danubium, quem et Istrum vocant.

115 OR II, 8 (PL 31, 763B): ... interrupto ponte Istrifluminis.

116 OR IV, 20 (PL 31, 910A-B): Basternarum gens ferocissima, auctore Perseo Philippi filio, praedarum spe sollicitata, et transeundi Istri fluminis facultate, sine ulla pugna vel aliquo hoste deleta est. Nam tunc forte Danubius, qui et Ister, crassa glacie superstratus, pedestrem facile transitum patiebatur.

117 Matijević Sokol - Sokol, Hrvatska i Nin I, 29. Usp. AG IV, vii, 4-7 (Bately, Old English Orosius, 99). 
redbe, a kao poticaj daljnjem istraživanju, nalazim vrijednim zaustaviti se na tome detalju: pišući o sukobu s “istarskim” Istranima Alfred za njih nekoliko puta rabi pojam Isprie ${ }^{118}$, dok govoreći o Istri kao geografskom pojmu u razmatranom odlomku (dva puta) upotrebljava termin Istria. ${ }^{119}$ Za Istrane s donjega Dunava, kao što je uočeno, rabi izraz Hisdriane. Radi li se, dakle, zaista o namjernoj i isključivo Alfredovoj distinkciji ili je možda već i Orozije svjesno lučio ta tri pojma?

Poput AG-a, već i u OR-u nailazimo na sitnu, no možda ne i slučajnu jezičnu distinkciju. Naime, govoreći o ratu protiv Istrâ, Orozije spominje rimske "nove neprijatelje, Istre" (Istri, novi hostes). ${ }^{120}$ Međutim, opisujući rat koji je Filip Makedonski započeo (i pobjednički dovršio) protiv Skita 339. pr. Kr., Orozije piše o "ratu protiv Istrijaca" (Istrianorum bello) te u istome kontekstu spominje "kralja Istrijaca" (Istrianorum rege). ${ }^{121}$ Orozije, dakle, “jadranske” Istre (Istri) pojmovno razlučuje od crnomorskih „Istrijaca“ (Istriani). U prvome slučaju naziv plemena dao je ime pokrajini (Istri $\rightarrow$ Istria), dok je u drugome ime naroda očito geografskoga podrijetla tj. izvedeno iz imena grada (Istria $\rightarrow$ Istriani). Teško da je ovo razlikovanje slučajno. Međutim, iako je teško utvrditi slijedi li Alfred u tome Orozija, čini se da i on razlikuje “dvije Istre”. Za detaljniju argumentaciju bilo bi dakako potrebno temeljitije proučiti i raščlaniti, s jedne strane čitav Orozijev tekst (uzimajući u obzir i više rukopisnih obitelji njegove Historiae) te, s druge strane, čitav tekst Alfredove prilagodbe. Iako u dosad uočenoj Alfredovoj uporabi opreku Hisdriane vs. Istria, Isprie nalazim očiglednijom od potvrde o nazivanju Dunava Istrom, rasprava o "Istrima” i "Istrijcima”, ustvari, nije od ovdje presudne važnosti. Znatno je važnije uočiti brigu Alfredova predloška Orozija oko razlikovanja pojmova koji bi mogli izazvati pomutnju kod čitatelja. Na tome tragu valja se vratiti Katičićevu opažanju (koji sumnja da Orozije naziva Dunav Istrom) da on za Dunav upotrebljava (iako jedino u razmatranom odlomku!) isključivo izraz Danubius. Dio Orozijeva opisa zemalja između Dunava i Jadranskoga mora u Katičićevu prijevodu glasi:

\footnotetext{
118 AG IV, vii, 4-7 (Bately, Old English Orosius, 99).

119 AG I, i, 15-16 (Bately, Old English Orosius, 18).

120 OR IV, 13 (PL 31, 890A). Prema nekim izdanjima (usp. izdanje C. Zangeinmeistera iz 1889. koje rabi Križman, Antička svjedočanstva, 331; Katičić koristi Lindetovo izdanje iz 1990.), Orozijeva se grafija imena Istre i Istra bilježi kao Histria i Histri, dok su se u starijim izdanjima (poput npr. PL) izdavači držali oblika Istria i Istri.

121 OR III, 13 (PL 31, 822B).
} 
"Sada ću iznijeti sve što Dunav razdvaja od barbarske zemlje, pa do Našega mora. Mezija s istoka ima ušće rijeke Dunava, s jugoistoka Trakiju, s juga Makedoniju, s jugozapada Dalmaciju, sa zapada Istru, sa sjeverozapada Panoniju, sa sjevera Dunav. [...] Dalmacija ima s istoka Makedoniju, otkud bura puše ima Dardaniju, sa sjevera Meziju, sa zapada Istru i Liburnski zaljev i Liburnske otoke, s juga Jadranski zaljev. Panonija, Norik i Recija imaju s istoka Meziju, s juga Istru, s jugozapada Peninske Alpe, sa zapada Belgijsku Galiju, sa sjeverozapada vrelo Dunava i granicu koja između Dunava i Galije odvaja Germaniju od Galije, sa sjevera Dunav."122

Iz navedenoga nedvosmileno proizlazi da u konkretnom ulomku Orozije za Dunav uistinu rabi isključivo ime Danubius. Međutim, vraćajući se time pitanju šire uporabe “dvostrukog imena” za Dunav u Orozijevu djelu, čini se da su za njega, na drugim mjestima u tekstu, Dunav (Danubius) i Ister (Ister) ipak istoznačnice. Shodno tome, a na tragu Katičićeva naputka o nužnosti uočavanja "porabe toga imena u zemljopisu Alfredova predloška Orozija"123, očito je da su i za Orozija i za njegova anglosaskoga nasljedovatelja Dunav i Ister općenito uzevši istoznačnice. Zašto je Orozije Dunav upravo u razmotrenom odlomku nazvao isključivo Danubius kada je jasno da poznaje i koristi se obama nazivima? Kao jedan od moguće uvjerljivih odgovora na to pitanje gotovo se nameće pretpostavka da je to učinio pazeći da ne bi čitatelj pobrkao Dunav s Istrom o kojoj je riječ u istom ulomku. Pretpostavljajući, nadalje, da je Alfred čitajući Orozija shvatio njegovu nakanu, čini se neobičnim zašto bi uveo riječ Ister (štoviše u obliku Istria) kao ime za Dunav (koji inače redovito naziva Donua) upravo na mjestu gdje ono može izazvati pomutnju. Odbacivanje te malo vjerojatne pretpostavke osnažuje Katičićevo mišljenje da se "Dunav u vezi s opisom Dalmacije uopće ne

122 Katičić, "Dalmatia", 84-85. OR I, 2, 23-24 (PL 31, 686A-687A): Nunc quidquid Danubius a barbarico ad mare Nostrum secludit, expediam. Moesia ab oriente habet ostia fluminis Danubii, ab euro Thraciam, a meridie Macedoniam, ab africo Dalmatiam, ab occasu Istriam, a circio Pannoniam, a septentrione Danubium (...) Dalmatia habet ab oriente Macedoniam, ab aquilone Dardaniam: a septentrione Moesiam, ab occasu Istriam, et sinum Liburnicum, et insulas Liburnicas: a meridie Adriaticum sinum. Pannonia, Noricus, et Rhetia habent ab oriente Moesiam, a meridie Istriam, ab africo Alpes Penninas, ab occasu Galliam Belgicam, a circio Danubii fontem et limitem, qui Germaniam a Gallia inter Danubium Galliamque secernit, a septentrione Danubium et Germaniam. Izdanja Zangemeistera (CSEL 5, 1882.) ili Lippolda (Orosio, Le storie contro i pagani, ed. Adolf Lippold, vol. I-II, Milano ${ }^{4} 2001$.) donose novu numeraciju Orozijevih poglavlja (prema njima citirani ulomak I, 2, 23-24 bio bi, ustvari, 1, 2, 54-55 [Mezija] odnosno 1, 2, 59-60 [Dalmacija]). Iako se Migneovo izdanje danas smatra zastarjelim i nekvalitetnim, navedena izdanja nisam iz tehničkih razloga bio u prilici konzultirati, što ne umanjuje moju zahvalnost anonimnom čitatelju ovoga članka koji me je na to upozorio. 
spominje”. Međutim, znajući da je autor AG-a kao predložak rabio i druge izvore osim OR-a (što je više no očito u ulomcima za koje nije imao oslonca u Orozijevu tekstu), upozorio bih na nekoliko izvora koji kronološki stoje između OR-a i AG-a koje valja uzeti u obzir - ako ne kao direktne predloške - no svakako kao odraz Alfredu suvremene percepcije razmatranoga dijela europskoga prostora.

\section{Izidor Seviljski (560. - 636.)}

Za ovu su raspravu osobito vrijedni i znakoviti zemljopisni podatci sačuvani u Etimologijama Izidora Seviljskog, jednom od najčitanijih djela i neizostavnom izvoru "svekolikoga" znanja ranoga srednjovjekovlja. ${ }^{124}$ Sakupivši i saževši ostatke antičke "geografske paradigme”, Izidor je sačuvao obilje podataka iz klasične geografije, no čija uporaba ipak ukazuje na nepoznavanje (?) prostornih odnosa već donekle preoblikovanih "stvarnim stanjem” njegova vremena. ${ }^{125}$ Izidorovo poimanje zemljopisa nekadašnjega Ilirika uvelike je ovisno o Orozijevu tekstu, no postoje naznake da je autor AG-a pred sobom imao i Etimologije te se tu i tamo oslonio na njih, prije nego na izvorni Orozijev tekst. U opisu Europe, sačuvanom u XIV. knjizi, može se pročitati:

"Pokrajine koje Dunav dijeli od barbarskog područja prema Sredozemnom moru su: prva je Mezija, nazvana po obilnoj žetvi te su je stari nazivali Cererinom žitnicom. Ova je pak s istoka povezana dunavskim ušćem, s jugoistoka uistinu Trakijom, s juga Makedonijom, sa zapada povezana je s Istrom. Poslije Mezije jest Panonija. Ondje je Norik, hladno područje slabe plodnosti."126

Opisujući položaj Dalmacije, Izidor nadalje objašnjava da postoji:

"Sedam grčkih pokrajina: od kojih je prva sa zapada Dalmacija, zatim Epir, zatim Helada, zatim Tesalija, zatim Makedonija, zatim Ahaja, te dvije na moru, Kreta i Cikladi. Ilirik općenito označava čitavu Grčku. Za Dalmaciju se smatra da je dobila ime

124. Tekst navodim prema: Isidori Hispalensis Episcopi Etymologiarum siue Originum libri XX, 2 vols. (dalje: Isidorus, Etymologiae), ed. Wallace Martin Lindsay, Oxford 1911.

125 O Izidoru kao geografu vidi: Merrills, History, 170-228.

126 Isidorus, Etymologiae, XIV, 4, 5: Prouincias autem quas Danubius a Barbarico ad Mediterraneum mare secludit: prima est Moesia, a messium prouentu uocata; unde et eam ueteres Cereris horreum nuncupabant. Haec autem ab oriente ostiis Danubii iungitur, ab Euro uero Thraciae, a meridie Macedoniae, ab occasu Histriae copulatur. Post Moesiam autem Pannonia est. Inde Noricus ager frigidus et parcius fructuosus. 
po Delmi, najznačajnijem gradu one pokrajine. Graniči na istoku s Makedonijom, na sjever s Mezijom, sa zapadne strane završava Istrom dok s južne strane završava Jadranskim morem.”127

Izidor će dodati i to da Makedoniji "na zapad leži Dalmacija” (ab occasu Dalmatiae). ${ }^{128}$ Konačno, za ovu je raspravu osobito značajan Izidorov opis Panonije:

"Panonija se naziva prema Apeninskim Alpama koje je dijele od Italije [...] okružena je dvjema vrlo brzim rijekama, Dravom i Savom. Povezana je s Norikom i Recijom; istočno od nje leži Mezija, jugoistočno Istra, jugozapadno Apeninske Alpe, na zapad Belgijska Galija, na sjever izvor Dunava i granica koja dijeli Germaniju i Galiju. Rijeka Ister, koja protječe kroz tu zemlju, daje Istri ime. Poznata je također i kao Dunav. Panonija se nalazi sjeverno od Istre." 129

Osim što potvrđuje “dvoimenost” Dunava, za ovu su raspravu svakako zanimljive Izidorove opaske da Istra leži “jugoistočno od Panonije” te da se "Panonija nalazi sjeverno od Istre". Nadalje, rečenica "Rijeka Ister, koja protječe kroz tu zemlju, daje Istri ime” dopušta više mogućnosti različitih tumačenjâ Izidorova shvaćanja geografije toga prostora. Ponajprije, koja je to za Izidora eius terra - Panonija ili Istra? Iz današnje perspektive čini se očitim da Izidor misli na Panoniju, no moguća višeznačnost toga i drugih sličnih formulacija u navedenom ulomku sasvim izvjesno nije pridonijela razumijevanju toga odlomka za autore koji će se tijekom vremena osloniti na njegov autoritet. Štoviše, drugačijim čitanjem razmotrenoga teksta (tj. nepoznavanjem "stvarne geografije”) moglo bi se zaključiti da za Izidora (kao i neke od njegovih predšasnika), ne samo da se "Istra zove po Istru", već i da on "protječe kroz nju”. ${ }^{130}$ Međutim, ako takvo čitanje navoda iz Eti-

127 Isidorus, Etymologiae, XIV, 4, 7-8: Sunt autem provinciae Graeciae septem: quarum prima ab occidente Dalmatia, inde Epirus, inde Hellas, inde Thessalia, inde Macedonia, inde Achaia, et duae in mari, Creta et Cyclades. Illyricus autem generaliter omnis Graecia. Dalmatia a Delmi maxima eiusdem provinciae civitate traxisse nomen existimatur. Adhaeret autem ab oriente Macedoniae, a septentrione Moesiae, ab occasu Histria terminatur, a meridie vero Adriatico sinu clauditur.

128 Isidorus, Etymologiae, XIV, 4, 13.

129 Isidorus, Etymologiae, XIV, 4, 16-17: Pannonia ab Alpibus Appenninis est nuncupata, quibus ab Italia secernitur [...] duobus satis acribus fluviis, Dravo Savoque, vallata. Coniungitur autem cum Norico et Raetia; habentes ab oriente Moesiam, ab Euro Istriam; ab Africo vero Alpes Appenninos habent, ab occasu Galliam Belgicam, a septentrione Danubii fontem, vel limitem qui Germaniam Galliamque secernit. Istriam Ister amnis vocavit, qui eius terram influit. Ipse est Danubius. Habet autem Istria a septentrione Pannoniam.

130 Npr. Pomponijev Opis mjestâ (usp. Križman, Antička svjedočanstva, 252-253). 
mologijâ i jest netočno, nema nikakve sumnje, kao što ću pokazati, da je bilo autora koji su ga upravo tako shvatili. O očitim zabunama (prouzročenim nepoznavanjem prostora i pogrešnim čitanjem oskudnih podataka sačuvanih u raznim sažetcima starijih autora) svjedoči više izvora iz "mračnih stoljeća” prijelaza iz kasne antike u rani srednji vijek.

\section{"Varia Geographica"}

Ranosrednjovjekovni opis Italije poznat pod imenom De terminatione prouinciarum Italiae, ${ }^{131}$ čiji se nastanak smješta u 7. stoljeće, opisujući Veneciju kao "prvu italsku pokrajinu”, bilježi da se "njezina granica proteže od krajeva Panonije sve do rijeke Adde” (...eius terminus a Pannonie finibus usque Adduam flumen protelatur). ${ }^{132}$ Nekoliko redaka niže isti izvor bilježi da su "Venecija i Histrija povezane u jednu pokrajinu” te da, štoviše, jedno od imena te pokrajine "potječe upravo od imena rijeke Hister" (Venetie Histrie connectitur et utreque una prouincia abentur (...) Hystria ab Hystro flumio nominatur). ${ }^{133}$ Konačno, u jednom od rukopisa toga teksta i sama se pokrajina naziva isključivo Histrijom, a njezino se ime izvodi iz Histra (Prima est Histria que ab Histro... fuisse perhibetur). ${ }^{134}$ Smatrajući tako određenu Histriju italskom pokrajinom, autor De terminatione još uvijek čvrsto stoji unutar relativno precizne rimske geografije. Međutim, povezujući u istom odlomku italsku pokrajinu s Dunavom autor, pokazujući određeni odmak od "administrativnoga shvaćanja”, otvara mogućnost (barem na etimološkoj razini) "uskrsavanja” staroga shvaćanja o vezi između Dunava i sjevernoga Jadrana. S druge strane, stapanjem nekadašnja dva područja Desete regije, otvaraju se nove mogućnosti tumačenja prostiranja granica najistočnije italske pokrajine.

Možda je upravo za taj uočeni/pretpostavljeni “značenjski pomak” ilustrativan primjer geografskoga spisa De provinciis Italiae seu Catalogus Proviniciarum Italiae ${ }^{135}$, koji Istru više ne navodi kao dio Italije. ${ }^{136}$ Štoviše, u opisu najsjevernije italske pokrajine u tom spisu nema ni spomena Istri,

131 De terminatione prouinciarum Italiae (dalje: De terminatione), u: Itineraria et alia geographica (dalje: Itineraria), Corpus Christianorum, Series Latina (dalje: CCSL), CLXXV, Turnhout 1965., 347-363.

132 De terminatione, 2, 10-11 (Itineraria, 350).

133 De terminatione, 2, 14-16 (Itineraria, 351).

134 De terminatione, var. (Itineraria, 350).

135 De provinciis Italiae seu Catalogus Proviniciarum Italiae (dalje: De provinciis), u: Itineraria, 365-368. Iako neki autori smatraju tekst starijim od Pavla Đakona, prevladavajuće je mišljenje da je nastao krajem 9. ili početkom 10. st. te je, sasvim izvjesno, mlađi od De terminatione (vidi: Itineraria, 366).

$136 \mathrm{Na}$ tome je tragu možda moguće upozoriti i na malo korišten izvor tzv. Historia inventionis s. Apollinaris episcopi et martyris gdje stoji da je naslovni mučenik (i ravenski biskup) djelovao u Istria provincia quaedam est in partibus Illyricis, o čemu vidi: Rajko Bratož, Il cristianesimo aquileiese, Udine 1999., 88, bilj. 165. 
Istru ili Panoniji. ${ }^{137}$ Bi li bilo preuzetno zaključiti da taj primjer ukazuje na postupno nestajanje pojma Istria iz "italocentrične” geografske vizije? ${ }^{138}$ Iako bi takav zaključak vjerojatno bio preuranjen, autorovo tumačenje da Hystria ab Hystro fluuio nominatur jasno svjedoči o preživljavanju starije kontaminacije u ranosrednjovjekovnom ruhu. Iz toga je ipak moguće izvesti zaključak da su ostatci klasične "mitske" kontaminacije, usprkos odbacivanju od strane autoriteta poput Strabona ili Plinija, preživjeli i, čini se, oživjeli u doba raspada ujednačene i relativno precizne rimske geografske paradigme. Nema dokaza da bi tko u 8. ili 9. st. smatrao da Dunav utječe u Jadran, no opća nesigurnost i raspad administrativnoga ustroja na tome prostoru tijekom nekoliko stoljeća, u kombinaciji s etimologiziranjem tadašnjih pisaca, svakako su otvorili nove mogućnosti “zamućivanja” postojećega geografskoga pojmovlja. Izvrstan primjer uočenoga pruža spomenuto neobično, kao izvor vrlo problematično, djelo sačuvano pod imenom Cosmographia, koje opisuje putovanja zagonetnoga Etika Istranina (Aethicus Ister) i čiji nastanak suvremena historiografija smješta u 7. ili 8. st. ${ }^{139}$ Taj tekst, očito potpuno ovisan o Opisu svijeta Julija Honorija, pokazuje kako nejasan izričaj poput onoga da se "Sava naziva i Hister" može biti sačuvan i prenošen stoljećima, postajući mogućim predmetom zabune i kod znatno mlađih autora, kao što ćemo vidjeti na primjeru tzv. Zemljovida Henrika iz Mainza.

Usporedba više suvremenih tekstova upućuje na oprez kod zaključivanja o zemljopisnom znanju određenoga razdoblja. Kao što pokazuje usporedba djela poput Opisa svijeta tzv. Ravenskoga Geografa i onoga nazvanoga prema Etiku Istraninu ( $\mathrm{u}$ isto vrijeme), različiti su autori sastavljali djela toliko različita da je teško govoriti o nekom zajedničkom geografskom znanju. To pak opažanje upozorava na važnost temeljitoga poznavanja izvora, predložaka i - ipak preciznoga - značenja koje pojedini autor pridijeva svojim zemljopisnim pojmovima.

137 De provinciis, 1, 2-6 (Itineraria, 367).

198 Nešto stariji tekst Versus de Asia et de uniuersi mundi rota (o. 636. - 736.) "opisujući” isti prostor ispušta Istru: Vnde Gothia emanat aduersus Dalmatia / / Pannonia, a Penninis nomen que conglomerat. (Itineraria, 446)

139 Najnovije izdanje priredio je Michael Herren kao: The Cosmograpahy of Aethicus Ister: Text, Translation, and Commentary, Publications of the Journal of Medieval Latin 8, Turnhout 2011. O vremenu nastanka i autorstvu vidi također i: Michael Herren, “The 'Cosmography' of Aethicus Ister: Speculations about its date, provenance, and audience”, u: Nova de Veteribus, hg. Andreas Bihrer und Elisabeth Stein, München 2004., 79-102. U kontekstu ove rasprave možda je vrijedno spomenuti da je za razumijevanje "Etikova" viđenja položaja Istre važno podsjetiti na njegovu ovisnost o Izidoru Seviljskom te je stoga u pravu B. Zlobec kad zaključuje da „Histria obsega za Etika ali za njegov vir istrski polotok in verjetno še noriškopanonsko zaledje“ (Barbara Zlobec, "Etik Hister in njegova Kozmografija“, Zgodovinski časopis, 5, 200o., $11-12)$. 


\section{Anonim Ravenjanin (7. st.?)}

U historiografiji se pod uvriježenim imenom Ravenskoga Geografa (Geographus Ravennas) ili Anonima Ravenjanina / Ravenskoga Anonima (Anonymus Ravennas) skriva nepoznati autor koji je, prema vlastitim riječima, na poticaj nekog Odona (ili Odokara), sastavio opis svijeta, pretpostavlja se, u drugoj polovici 7. st. ${ }^{140}$ Ravenjaninov Opis svijeta (Cosmographia) opisuje čitav tada poznati svijet donoseći među ostalim vrlo vrijedne podatke i o krajevima uz istočnu obalu Jadrana. ${ }^{141}$ Jedna od vrlo zanimljivih karakteristika spisa jest autorovo kombiniranje klasičnoga rimskoga provincijskoga i "regionalnoga" nazivlja. Ravenjaninov je Opis svijeta obilato rabio i srednjovjekovni geograf Gvidon Pizanac, o čijem će djelu biti riječi nešto dalje. ${ }^{142}$

Opis i određenje Istre javlja se u Opisu svijeta na više mjesta započevši s onim iz prve knjige gdje se govori o "Zapadnome zaljevu” qui remigatur iuxta litus maris a loco, qui dicitur Diana, qui est sub Durachium, per Dalmatias, Striam et Venetias. ${ }^{143}$ Smještaj Istre određen je u Ravenjaninovu opisu Ilirika (patria quae dicitur Illyricus) ${ }^{144}$ riječima: item iuxta ipsam Liburniam litus Mare Magnum est patria que dicitur Ystria, que ex Italia pertinet. Da Istru smatra dijelom Italije, potvrđuje navod iz četvrte knjige gdje stoji Que Italia habet infra se provincias famosissimas decem et octo, id est Liguria, provincia Venetiarum, Histria. ${ }^{145}$ Nadalje, Ravenjanin, nakon detaljnoga popisa civitates Venecije ${ }^{146}$ donosi najprije "kratak popis" istarskih gradova, ${ }^{147}$ a potom i

140 Oko datiranja Opisa svijeta ne postoji konsenzus. Smješta ga se i u 6. st. (usp. Križman, Antička svjedočanstva, 355), pa čak i u 8. st. (npr. Kai Brodersen, “Geographus Ravennas”, u: Neue Pauly, vol. 4). Usp. i Hrvoje Gračanin, Južna Panonija u kasnoj antici i ranom srednjovjekovlju, Zagreb 2011., 235-236, bilj. 19 (prva pol. 9. st.).

141 Detaljnije o Ravenjaninovu opisu istočne jadranske obale i unutrašnjosti vidi: Slobodan Čače, Civitates Dalmatiae u "Kozmografiji" Anonima Ravenjanina, Zadar 1995. O značenju Ravenjaninova spisa za određivanje granica Istre i Liburnije osobito Mate Suić, "Liburnia Tarsaticensis", Adriatica praehistorica et antiqua, Zagreb 1970., 705-716, i Lujo Margetić, "Noviji pogledi na stariju povijest Vinodola, Krka i Senja”, Zbornik Pravnog fakulteta u Rijeci, 9, 1988., 1-19. O Opisu svijeta i vezama s Peutingerovim zemljovidom te Antoninskim opisom putova vidi ukratko kod: Križman, Antička svjedočanstva, 352-373. Usp. i Radoslav Katičić, "Filološka razmatranja uz izvore o začecima hrvatske države”, u: Radoslav Katičić, $U z$ počttke hrvatskih početaka. Filološke studije o našem najranijem srednjovjekovlju, Split 1993., 37-41, te novije radove: Tin Turković, "Prikaz hrvatskog povijesnog prostora na Peutingerovoj karti - Dijanin hram na Marjanu u svjetlu novih spoznaja”, u: Stjepan Gunjača i hrvatska srednjovjekovna povijesno-arheološka baština, 1, ur. Tomislav Šeparović - Nikolina Uroda - Mate Zekan, Split 2010., 127-145.

142 Tekst navodim prema: Ravennatis anonymi cosmographia et Gvidonis geographica, ed. Moritz Eduard Pinder et Gustav Parthey, Berolini 1860., i Ravennatis Anonymi Cosmographia et Guidonis Geographica, ed. Joseph Schnetz, u: Itineraria Romana II, Lipsiae 1940. (dalje: Anonymus, Cosmographia). Navodi se odnose na broj knjige i paragrafa te (u zagradi) broj stranica u berlinskom/leipziškom izdanju.

143 Anonymus, Cosmographia, I, 17 (38, 6-9 / 14).

144. Isto, IV, 15-22 (205,3-225,5 / 54-59).

145 Isto, IV, 29 (247,7-9/65).

146 Isto, IV, $30(253,14-255,6 / 67)$.

147 Isto, IV, $30(255,7-15 / 67)$. 
“dug popis” gradova između Raše i Ravene ${ }^{148}$ (u kojoj, kako skromno dodaje “idiota ego... genitus sum”). U istoj se knjizi opisuju i krajevi Italije prema Alpama i patriae koje se ondje nalaze. ${ }^{149}$

Rijeku Dunav Ravenjanin spominje pod imenom Danubius na više mjesta, među kojima na nekoliko očito u značenju “donjega Dunava”, pa čak i ušća Dunava: usque introitum Danubii fluminis in mare ${ }^{150}$ ili ad partem septentrionalem Danubii ${ }^{151}$. Spominjući “Ahilejev otok” u Crnome moru, Ravenjanin također bilježi ime Danubius ${ }^{152}$. Ukratko, na temelju razmotrene uporabe pojmova Danubius i Hister u Opisu svijeta Anonima Ravenjanina, može se zaključiti da on Dunav naziva isključivo Dunavom, dok pojam Ister uopće ne rabi. Anonim se, nadalje, čini potpuno imunim na stoljetne kontaminacije Istre i Dunava. Naime Istru (upotrebljavajući oblike Istria i Histria) spominje gotovo isključivo u "administrativnome smislu”, bez mitskih dimenzija i brkanja s prostorom izvan poluotoka. Stoga se Ravenjanina može smatrati dobrim Plinijevim učenikom koji ne ostavlja mnogo prostora izvođenju ekstravagantnih zaključaka.

\section{Pavao Đakon (0. 720. - 0. 799.)}

Nešto mlađi od Ravenjanina, vrlo važan autor za ovu raspravu jest i Pavao Đakon, autor brojnih djela od kojih je najpoznatije svakako Povijest Langobarda. Đakonovu djelu vjerojatno nije potreban uvod. ${ }^{153}$ Njegova je dragocjenost za izučavanje povijesti i zemljopisa (prije svega) Italije između 6. i ranoga 8. st. nezamjenjiva. U ovdje razmatranome kontekstu osobito su vrijedni podatci koje Pavao donosi o krajnjem italskome sjeveroistoku. U opisu administrativnoga uređenja predlangobardske Italije on se vjerojatno, poput spominjanoga spisa De terminatione, među ostalim predlošcima oslonio i na nepoznati zemljopisni predložak starïi od 7. st. ${ }^{154} \mathrm{U}$ tome je smislu osobito zanimljivo obratiti pozornost na njegovo kombiniranje kla-

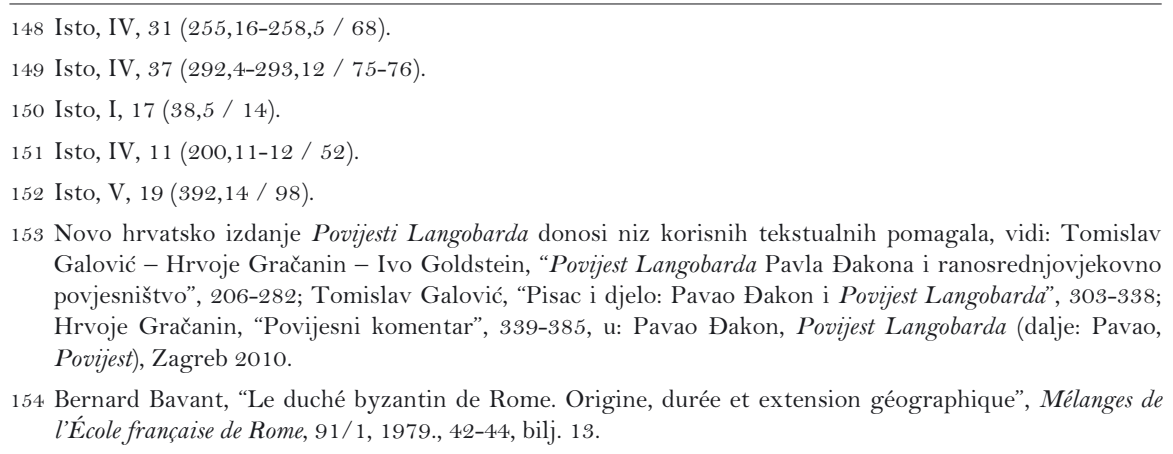
Galović - Hrvoje Gračanin - Ivo Goldstein, "Povijest Langobarda Pavla Đakona i ranosrednjovjekovno povjesništvo", 206-282; Tomislav Galović, "Pisac i djelo: Pavao Đakon i Povijest Langobarda", 303-338; Hrvoje Gračanin, "Povijesni komentar", 339-385, u: Pavao Đakon, Povijest Langobarda (dalje: Pavao, Povijest), Zagreb 2010.

154 Bernard Bavant, "Le duché byzantin de Rome. Origine, durée et extension géographique", Mélanges de l'École française de Rome, 91/1, 1979., 42-44, bilj. 13. 
sičnih predložaka s inovacijama pri određivanju granica italskih pokrajina. O Veneciji Pavao piše da se:

“...njezino područje prostire od granica Panonije sve do rijeke Adue. Dokazuje se to u knjigama anala u kojima se grad Pergam drži venetskim. U povijesnim knjigama također čitamo ovo o jezeru Benak: »Venetsko jezero Benak [Lago di Garda], iz kojeg istječe rijeka Mincij.«"155

Nakon prisjećanja na etimologiju imena Veneti (od Eneti tj. Aineto ${ }^{=}$ hvalevrijedni) nastavlja:

"S Venecijom je povezana Istra i obje se smatraju jednom provincijom. Istra je pak dobila ime po rijeci Histru. Ona je, prema Rimskoj povijesti, nekoć bila veća nego što je danas. Glavni je grad ove Venecije bila Akvileja; sad je to umjesto nje Forojulij...”

U Pavlovoj Povijesti osobito je zanimljivo, poput stoljeća mlađeg AG-a, uočiti spoj klasične geografije i autoru suvremenih podataka. U tome smislu nalazim osobito zanimljivim opažanje da je središte najistočnije italske pokrajine u Pavlovo vrijeme Forojulij. Stoga bi se pitanje opsega i granica “združenih" Venecije i Istre moglo preoblikovati kao: kojim prostorom upravlja (de facto i/ili de jure) vlast smještena u ranosrednjovjekovnom Forojuliju? Pitanje je to koje zavrjeđuje osobitu pažnju, no koje zbog svoje složenosti zahtijeva zasebnu raspravu.

\section{Karolinški pisci 9. stoljeća}

Uspostavom karolinške vlasti nad dijelom sjevernoga Jadrana i istočnoalpskoga prostora, a potom i prodorom franačkih vojski u dubinu Panonije, Istra i znatni dijelovi Dunava ponovno su se, nakon dugo vremena, našli u istoj državi. Je li ta činjenica, i na koji način, mogla utjecati na percepciju njihova međusobnoga odnosa? Upozoravajući na važnost načina na koji "germanski geografi i kartografi imenuju ili označuju Dunav", Sokolovi su iznijeli pretpostavku da upravo "oni protežu naziv Histria-Hister i na sred-

155 Paulus, Historia, II, 14. Pavao u Rimskoj povijesti Bergamo smješta u Veneciju (Pavao, Povijest, 227, bilj. 186). Citat o jezeru Benak preuzeo je od Izidora Seviljskog (usp. Isidorus, Etymologiae, XIII, 19, 7; Pavao, Povijest, 227, bilj. 188).

156 Paulus, Historia II, 14. Venetia et Histria je deseta pokrajina Italije od vremena cara Augusta (27. pr. Kr. - 14.); Pavao, Povijest, 227, bilj. 190. Komentator upozorava da je Pavlovo pogrešno etimologiziranje utemeljeno na Izidoru (Isidorus, Etymologiae, XIV, 4, 17.). O tome i Pavlovoj pretpostavci da je Istra nekoć bila znatno veća nego u njegovo vrijeme vidi objašnjenje u: Pavao, Povijest, 228, bilj. 191-192. 
nji i na gornji tok Dunava"157 te da je upravo "preko tog bavarskog kruga, oblik Ister-Istria mogao otići daleko na zapad." ${ }^{58}$ Nastojeći provjeriti održivost te pretpostavke, promotrit ćemo, na tragu dosadašnjeg istraživanja, uporabu imenâ za Dunav i Istru u nekoliko relevantnih tekstova nastalih u 9. stoljeću. Ne treba naglašavati da su odabrani izvori, kao i u slučaju razmotrenih klasičnih autora, tek uzorak (nadam se relevantan) za shvaćanje jednoga od aspekata ranosrednjovjekovne percepcije zemljopisa istočnoga oboda Franačkoga Carstva.

Među prvima - ovdje direktno relevantnima - svakako je nužno uzeti u obzir Pjesmu o vojvodi Eriku iz pera akvilejskoga patrijarha Paulina (787. - 802.). ${ }^{159}$ Naime, tugujući za nedavno stradalim prijateljem (radi se o furlanskom vojvodi Eriku, dobro poznatom u hrvatskoj historiografiji po pogibiji kod Tarsatike 799.), patrijarh nekoliko puta spominje Dunav i to pod oba njegova imena (Istris te Danubius) ${ }^{160}$. Da se radi o uobičajenoj uporabi potvrđuje isti autor i u svojem "transkriptu” Conventus episcoporum ad ripas Danubii, gdje je zabilježio da se sabor održao supra ripas Histri Danubii. ${ }^{161}$

Nekoliko desetljeća nakon Paulinovih stihova, sastavio je Einhard (o. 775. - 840.) svoj Životopis Karla Velikoga (Vita Karoli Magni). Usprkos ogromnome značaju toga spisa za rekonstukciju Karlova života i vladavine, za ovdje razmatranu problematiku Vita Karoli sadrži prilično skroman materijal. Istru i Dunav Einhard spominje isključivo u 15. poglavlju nabrajajući područja koja su se našla pod vlašću Karla Velikog. Uporaba nazivlja potvrđuje uporabu uočenu u drugim suvremenim izvorima; Dunav se spominje svega tri puta i to isključivo kao Danubius, a Istra (Histria) tek jednom. Ulomak glasi:

“Osvojio je i obje Panonije i Daciju, smještenu na drugoj obali Dunava, a također i Istru, Liburniju i Dalmaciju, izuzevši primorske gradove koje je prepustio konstantinopolskom caru zbog prijateljstva i ugovora sklopljenog s njime. Pokorio je zatim sve

\footnotetext{
157 Matijević Sokol - Sokol, Hrvatska i Nin II, 28.

158 Isto, 29.

159 Paulinus Aquileiensis, Versus de Herico duce, MGH, Poetae Latini aevi Carolini, 1, ed. Ernst Dümmler, Berlin 1881., 131-133 (dalje: Paulinus, Versus). Novije izdanje Paulinovih djela nije mi nažalost bilo dostupno (vidi: Paulinus Aquileiensis, Opera II, Corpus scriptorum Ecclesiae Aquileiensis [dalje: CSEA], 10/2, ed. Alessio Peršič - Sandro Piussi, Roma 2007., 220-230.)

160 Paulinus, Versus, 131. Paulinovi stihovi, osim kao potvrda uporabe dvostrukoga imena Dunava, za ovu raspravu su vrlo zanimljivi i zbog "određivanja prostora Erikove nadležnosti”, što zavrjeđuje znatno temeljitije razmatranje.

161 Paulinus, Opera I, CSEA 10/1, ed. Giuseppe Cuscito, Roma 2007., 128.
} 
barbarske i divlje narode koji nastanjuju Germaniju između rijeka Rajne i Visle i između oceana i Dunava, po jeziku, doduše, dosta slične, ali po običajima i nošnji zaista veoma različite; sasvim ih je svladao i podvrgnuo danku." 162

Gotovo istovremeno sa Životopisom Karla Velikog sastavljen je ili redigiran značajan dio Anala Franačkog Kraljevstva (Annales regni Francorum, dalje: ARF), čiji autor Dunav spominje na desetak mjesta. Za ovu je raspravu važno (a vjerojatno i dovoljno) naglasiti sljedeće: autor ARF-a Dunav naziva isključivo Danubius, bilo da govori o njegovu gornjem toku u bavarskom kontekstu, ${ }^{163}$ bilo da opisuje napredovanje vojske u ratu protiv Avara ${ }^{164}$. Međutim, najvažnije je svakako uočiti da, opisujući događaje na srednjem, odnosno donjem toku Dunava (duces Slavorum circa Danubium habitantium), ${ }^{165}$ ili pak o dijelu Dunava pod bugarskom vlašću (Daciam Danubio), ${ }^{166}$ ARF bilježi isključivo ime Danubius, dok se Hister u tome spisu uopće ne spominje. Na Anale se djelomično oslanja i nešto kasnija Kronika (Chronicon) Reginona iz Prüma (o. 840. - 915.), u kojoj o Dunavu gotovo da i nema riječi; Reginon ga spominje tek jednom - kao Danubius. ${ }^{167}$ Slično svjedočanstvo donosi i Popis gradova i područja (Descriptio civitatum et regionum ad septentrionalem plagam Danubii) nastao, prema danas uglavnom prihvaćenome mišljenju, sredinom 9. stoljeća. Taj kratak spis, čije se sastavljanje pripisuje nepoznatom redovniku iz istočnih područja Carstva (pod imenom Bavarskog Geografa), Dunav spominje tek u naslovu, i to kao Danubius. ${ }^{168}$

Za raščlambu percepcije zemalja na istočnim granicama Carstva u 9. st. iz karolinške perspektive nezamjenjiv su izvor tzv. Fuldski anali (Annales

162 Einhard, Život Karla Velikog, prev. Zvjezdana Sikirić, Zagreb 1992. Einhardus, Vita Karoli, XV: post quam utramque Pannoniam et adpositam in altera Danubii ripa Daciam, Histriam quoque et Liburniam atque Dalmaciam, exceptis maritimis civitatibus, quas ob amicitiam et iunctum cum eo foedus Constantinopolitanum imperatorem habere permisit; deinde omnes barbaras ac feras nationes, quae inter Rhenum ac Visulam fluvios oceanumque ac Danubium positae, lingua quidem poene similes, moribus vero atque habitu valde dissimiles, Germaniam incolunt, ita perdomuit, ut eas tributarias efficeret.

163 ARF, a. 787: Danubium fluvium; a. 788: in Danubio fuvio; vjerojatno i a. 821.

164. ARF, a. 791: (više puta) de australi parte Danubio, de aquilonale parte Danubio, etc.

$165 \mathrm{ARF}$, a. 811.

$166 \mathrm{ARF}$, a. 824.

167 Reginonis abbatis Prumiensis Chronicon cum continuatione Treverensi (dalje: Regino, Chronicon), MGH, Scriptores rerum Germanicarum in usum scholarum ex Monumentis Germaniae historicis separatim editi (dalje: SSRG), 50, ed. Friedrich Kurze, Hannoverae 1890., a. 866, 85.

168 Descriptio je više puta objavljivan, a tekst jedinog rukopisa (MS Bayerischen Staatsbibliothek, München, Clm 560) dostupan je na svemrežnim stranicama te knjižnice. 
Fuldenses, dalje: AF) ${ }^{169}$ percipirani kao “istočna varijanta” nastavka ARF-a. U danas poznatome obliku AF je sastavljen od više dijelova koje je sastavljalo nekoliko autora između o. 840. i 900. Uglavnom, AF je zanimljiv za ovu raspravu stoga što na barem desetak mjesta spominje Dunav. ${ }^{170}$ Počevši od Meginharda, pretpostavljenoga autora trećega dijela AF-a, nailazimo na opis nesretnoga poraza Bavaraca od strane Moravljana na Dunavu: "Svatopluk je potajno poslao veliku vojsku i napao Bavarce koji su bili ostavljeni da čuvaju lađe na obali Dunava, te neke poklao, neke podavio u rijeci, a neke odveo u roblje."171 Ostavljajući za sada po strani vrlo zanimljiv podatak o brodovima na Dunavu, iz ovoga je navoda očito da franačke vojske tijekom ratnih operacija protiv Moravljana za plovidbu rabe Dunav koji autor naziva Histrom. Nadalje, opisujući tijek vojne protiv Moravljana desetak godina poslije, autor nastavka AF-a (tzv. Continuatio Ratisbonensis) pripovijeda o okrutnom sakaćenju zarobljenih Franaka "sa sjeverne strane rijeke Histra” (de septentrionali parte Histrifluminis), da bi već nekoliko redaka niže slanje kopljanika "preko Dunava” opisao riječima: ultra Danubium missis spiculatoribus ${ }^{172}$. Slanje vojske preko Dunava isti je pisac opisao još jednom riječima: missa quadam excercitus sui parte supra Danubium. ${ }^{173}$ Dunav se 889 . godine, u vezi sa smrću nadbiskupa Liutberta, spominje opet kao Hister. ${ }^{174}$ Konačno, dolazak Mađara u Panoniju opisan je riječima ultra Danubium peragrantes. ${ }^{175}$ Uzevši u obzir izloženo, može se zaključiti da različiti autori koji su nadopunjavali Fuldske anale upotrebljavaju oba imena za Dunav/Hister (u oblicima Danuvius/Danubius i Hister) istoznačno, no sa znatnom prevagom u korist Dunava.

Niz ovdje razmotrenih navoda možda bi se dao nadopuniti sličnim podatcima iz drugih suvremenih izvora, no već je i na temelju izloženoga moguće pretpostavkama iznesenim u dosadašnjoj raspravi pridodati sljedeća opažanja. Od sedam razmotrenih spisa, čak pet ih za Dunav upotrebljava isključivo ime Danubius. Paulinova Pjesma i AF potvrđuju uporabu

\footnotetext{
169 Navodim prema: Annales Fuldenses sive Annales regni Francorum orientalis (dalje: AF), ed. Friedrich Kurze, MGH, SSRG, 7, Hannover 1891.

170 Ako se prihvati interpretacija prevladavajuće historiografije koja operacije protiv Moravljana još uvijek smješta negdje na gornji tok Dunava, čini se da nema smisla pokušati praviti distinkciju između gornjega i donjega Dunava. Za sastavljače AF-a Hister je, u tom kontekstu, neupitno istoznačnica s Danubius.

171 AF, a. 872, 76: Zuentibald, misso clam exercitu copioso, Baioarios qui ad tuendas naves in littore Histri fluminis relicti fuerant, occupavit, et alios occidit, alios neccavit in fumine, alios vero captivos duxit.

$172 \mathrm{AF}$, a. $884,111$.

$173 \mathrm{AF}$, a. 884,112 .

174. $\mathrm{AF}$, a. $889,117$.

$175 \mathrm{AF}$, a. 894,125 .
} 
oba naziva, no češća uporaba imena Dunav upućuje na prevladavanje "rimskoga” nad "grčkim” imenom. ${ }^{176}$ Ta su opažanja za ovu raspravu značajna iz najmanje dva razloga. Kao prvo, ti izvori podupiru odbacivanje primjedbe da - kao i u slučaju navedenih starijih autora - pojmovi Dunav i Ister u ranome srednjem vijeku nisu smatrani istoznačnicama. Iz toga zaključka pak proizlazi da bi se Dunav (kao Hister) i Histria barem načelno mogli dovesti u vezu. Prihvaćanje toga opažanja povlači za sobom pitanje postavljeno tijekom rasprave: “Koje ime nadjenuti porječju rijeke koja se naziva Hister?”177 Međutim, prije odgovaranja na to pitanje, kao drugo važno opažanje, otvara se pitanje potvrđuje li ikoji ranosrednjovjekovni izvor (isključimo li zasad AG kao neposredan predmet rasprave) uporabu pojma Istria za Podunavlje (to jest porječje Istra)?

S obzirom na iznesenu pretpostavku o širenju toga pojma "daleko na zapad”, valja utvrditi da nigdje nije pouzdano dokumentirano korištenje izraza Histria za Dunav. ${ }^{178}$ Predočeni franački izvori doduše Dunav (iako rijetko) nazivaju Histrom, no ničime ne potvrđuju predloženo izjednačavanje pojmova Ister $\rightarrow$ Istria. Stoga, ukoliko se u raspravu ne uvede kakav dosad nekorišten izvor, iznesena se pretpostavka ne može prihvatiti. Dokazivati tezu navodom iz AG-a, osim što je očito neodrživo, značilo bi pristati na cirkularno određivanje značenja pojma. Kao što je više puta naglašeno, zapravo je, čini se, geografski argument, tj. pretpostavljeno smještanje Istre na sjever u "dubokom zaleđu" Dalmacije u AG-u, a ne precizna uporaba pojma, potaknulo Sokolove na zaključak da je riječ o Dunavu. ${ }^{179}$ Stoga, razmotrivši odabrane franačke izvore čini mi se nužnim, imajući na umu upravo taj "geografski aspekt" argumentacije, razmotriti i nekoliko dosad neuočenih detalja vezanih uz razmatrane ulomke AG-a.

176 AF ime Dunav bilježi čak 9 puta (4 puta kao Danuvius i 5 puta kao Danubius), a Hister tek 3 puta.

177 Matijević Sokol - Sokol, Hrvatska i Nin II, 25, u osvrtu na Franko Oreb, "Starohrvatska prosvjeta, III. serija, svezak 30, Muzej hrvatskih arheoloških spomenika, Split, 2003. (Kolege i prijatelji Dušanu Duji Jelovini)", Obavijesti Hrvatskog arheološkog društva, 36/3, 2004., 172.

178 Tezu o širenju imena Hister ne potvrđuju ni drugi ranosrednjovjekovni tekstovi. Npr. Ekhardova kronika iz 12. st., koja preuzima mnoštvo podataka iz ranijih anala, spominje Dunav na desetke mjesta, nikad ga ne nazivajući Istrom. Usp. Ekkehardi Uraugensis chronica, ed. Georg Heinrich Pertz, MGH, SS, 6, Hannover 1844.). "U tim okvirima" spomenuti Hunfrid jedini je primjer koji bi dao naslutiti da se pojam Istria mogao rabiti za područje uz gornji tok Dunava. No, osim što nije riječ o geografskom spisu (radi se o mlađem hagiografskom tekstu iz 11. st.), djelo u kojem se Hunfrid spominje kao upravitelj “čitave Istre" umnogome je problematičan izvor za povijest ranoga 9. stoljeća. Tim se problemom namjeravam temeljitije baviti u najavljenom članku.

179 Usp. Matijević Sokol - Sokol, Hrvatska i Nin II, 27, s naglaskom na pretpostavku da je "Istra kod Bugara". 


\section{Istra i Ister u Alfredovoj geografiji}

\section{1. Predlošci i narav zemljopisnog znanja AG-a}

O prvom poglavlju AG-a mnogo se raspravljalo, osobito u britanskoj historiografiji. Među ostalim postavljenim pitanjima, jedno je od najvažnijih bilo ono o naravi intervencija autora AG-a u Orozijev latinski original. ${ }^{180}$ $\mathrm{S}$ obzirom na opis dijela Europe koji je predmet ovoga razmatranja, prema mišljenju J. Bately, promjene su, u odnosu na predložak, “toliko radikalne da je moguće smatrati da je čitav odlomak promijenjen kako bi odgovarao, uz nešto iznimki, situaciji 9. st. kakvom ju je poznavao autor Alfredove geografije, ili njegov neposredan izvor." ${ }^{181}$ Drugim riječima, Bately je utvrdila ono što su, u hrvatskom kontekstu, naglasili Sokolovi uočivši da je autor AG-a u svoju obradu OR-a unio brojne elemente ranosrednjovjekovne "stvarne" geografije.

Ovdje ćemo taj problem razmotriti tek na jednom primjeru. Naime, u kontekstu rasprave o predlošcima AG-a, često je navođeno da je autor mogao doći do "novih podataka" iz raznih izvora: pretpostavljene mappa mundi, opisa ili komentara takvoga zemljovida, suvremenih latinskih i vernakularnih tekstova, ali i izjava očevidaca. ${ }^{182}$ Jedno od ponuđenih tumačenja bilo je ono prema kojem je autor AG-a većinu “novih podataka” preuzeo iz nepoznate mappa mundi. ${ }^{183}$ Više je autora uočilo da AG odražava "kartografski istok” tipičan za ranosrednjovjekovne mappae mundi uzimajući to kao argument u prilog tumačenju da je upravo nepoznati zemljovid poslužio kao predložak pri sastavljanju AG-a. ${ }^{184}$ Razmatrajući u tom kontekstu spomen “pustoši” između Karintije i Bugara, J. Linderski je čak zaključio da je autor AG-a pred očima imao zemljovid ili opis zemljovida na temelju Agripinih komentara i njegove, danas nepoznate, mappa mundi. ${ }^{185}$

Smatrajući tumačenje o mappa mundi kao predlošku načelno prihvatljivim, J. Bately je ipak upozorila na činjenicu da pristalice te teorije nisu uzeli u obzir sav materijal sadržan u AG-u te da shodno tome nisu ozbiljno

\footnotetext{
180 Bately, "The relationship", 45.

181 Isto, 52 .

182 Plod opisa očevidaca sasvim je sigurno opis Baltika "iz usta" Ohtherea i Wulfstana (usp. Niels Lund [ed.],

Two Voyagers at the Court of King Alfred: The Ventures of Ohthere and Wulfstan, York 1984.).

183 Ovo mišljenje zastupali su i Gerard Labuda, Źródła skandynawskie i anglosaskie do dziejów Stowiańszczyzny, Warszawa 1961., 12-14, passim, te Linderski, "Alfred the Great", 434-439.

184. Radi se o stranama svijeta koje određuju AG: Oriens (ušće Gangesa), Occidens (Heraklovi stupovi), Meridies (južno od Nila), Septentrio (rijeka Tanais). Bately, "The relationship”, 46.

185 Linderski, "Alfred the Great", 434-439.
} 
razmotrili moguća alternativna tumačenja podrijetla "novoga materijala” u AG-u. ${ }^{186}$ Raščlanjujući tekst u potrazi za dodatnim tumačenjem, Bately je uočila čitav niz primjera kod kojih bi bilo logičnije pretpostaviti uporabu tekstualnoga, a ne kartografskoga predloška. Za ovu je raspravu, osim vrijednog općeg zaključka o izvorima AG-a, ${ }^{187}$ vrlo dragocjeno autoričino upućivanje na nekoliko detalja vezanih uz "hrvatski dio" opisa. Naime, utvrdivši niz mogućih predložaka AG-a, Bately je usporedila spomen westen pat is betux Carendan on Pulgarum ${ }^{188}$ s Plinijevim izvještajem (gdje veliki prirodoslovac izvještava da se istočno od Norika nalaze deserta Boiorum) te podatcima sačuvanim u spomenutoj Dimensuratio. ${ }^{189}$ Uočavajući taj detalj, autorica je razmotrila pitanje različitih tumačenja prema kojima spomen pustoši u AG-u odražava suvremeno stanje u središnjoj Panoniji ${ }^{190}$ opustošenoj avarskim pohodima u 6. st. te ponovno tijekom pohoda Karla Velikog protiv Avara početkom 9. st. ${ }^{191}$ Linderski je upozorio na niz klasičnih autora koji spominju pustoši u Panoniji smatrajući da se i Alfred u tome oslonio na starije autore. ${ }^{192}$ Zaključivši da se radi o Panoniji istočno od Norika tj. Karintije, Linderski je ustvrdio da se podatak iz AG-a ni u kojem slučaju ne može rabiti da bi se utvrdila granica između Moravske i Bugara. ${ }^{193}$

Ukratko, uzevši u obzir višeslojnost iznesenoga problema, vrlo je teško prosuditi je li sastavljač AG-a pred očima imao višestoljetnu percepciju dijela Panonije kao pustoši (čiji se korijeni mogu naći još kod pisaca poput Herodota) ili je podatak o pustoši preuzeo iz mlađega (pa ako i suvremenoga) izvora. U dosadašnjoj diskusiji Sokolovi su naveli niz karolinških autora od Einhardove Vita Karoli, preko Salzburških anala (858.) sve do Kronike Reginona iz Prüma (888.) (!) sa zaključkom da se radi o Panoniji “između Alpa,

\footnotetext{
186 Bately, "The relationship", 46.

187 Isto, 59

188 Ista, Old English Orosius, 18.

189 Ista, "The relationship", 53. Na vezu između Plinija i ranosrednjovjekovnih izvora u "regionalnom kontekstu” upozorila je Bruna Kuntić Makvić, "La continuité de la mentalité urbaine: de Pline l'Ancien à Constantin Porphyrogénète", Hortus artium medievalium, 4, 1998., 231-237.

190 Robert Thomas Hampson je u predgovoru Bosworthovom izdanju iz 1859. iznio mišljenje da se radi o "pustoši sjeverno od Drave, istočno od Klagenfurta". Kemp Malone je pustoš poistovjetio s Panonijom te kao i mnogi drugi istraživači smatrao da se radi o "autentičnom doprinosu anglosaskog sastavljača AG" zemljopisnom znanju o panonskom prostoru (usp. Kemp Malone, "King Alfred's North: A Study in Mediaeval Geography" [dalje: Malone, "King Alfred's North"], Speculum, 5/2, 1930., 139-167). Više je autora smjestilo Alfredovu pustoš na područje između Moravske i Bugarske, "negdje oko rijeke Tise". Linderski, "Alfred the Great", 437.

191 Bately, "The relationship", 53.

192 Linderski, "Alfred the Great", 438-439.

193 Isto, 439, bilj. 25.
} 
Blatnog jezera i Dunava”. ${ }^{194}$ Taj se zaključak poklapa s mišljenjem većega broja istraživača AG-a te se može smatrati utemeljenim. Rasprava pak o naravi i podrijetlu toga podatka ipak upozorava na činjenicu da je u slučaju Alfredove pat westen vrlo teško odrediti radi li se, kako su mnogi smatrali, “doprinosu AG-a poznavanju prostora ranosrednjovjekovne Panonije” ili se radi tek o općem mjestu iz starije geografske literature. Upozorivši na oba mišljenja, dodao bih da ne vidim zašto bi jedno tumačenje nužno isključivalo drugo. Naime, autor AG-a mogao je, poput Einharda početkom 9. st., imati na raspolaganju podatke o stvarnom stanju u Panoniji, no spomen pustoši uobličiti po uzoru na klasične autore, smještajući je ondje gdje su je smještali i oni - na uvelike opustošeni prostor Panonije na koji će ubrzo po sastavljanju AG-a prispjeti prve skupine Mađara. ${ }^{195}$

\section{2. O stranama svijeta u $A G-u$}

Opažanja o smještaju Alfredove pustoši potiču temeljito razmatranje međusobnoga odnosa pokrajina o kojim je ovdje riječ. Naime, vrlo važan argument u prilog mišljenju Sokolovih da je Alfredova Istra ustvari Dunav jest upravo na prvi pogled neobičan odnos među pokrajinama koje opisuje AG. Konkretno, činjenica da se prema Alfredu Istra nalazi "sjeverno od Dalmacije” jedan je od ključnih argumenata iznesenih u prilog mišljenju da se radi o Dunavu. Međutim, uz “doslovno čitanje” AG-a postoji više mogućnosti "nijansiranijega” tumačenja tih nesklapnosti (koje su Katičiću poslužile kao dokaz o netočnosti AG-a). Sve u svemu, može se reći da je Alfredov opis “jugoistočne Europe” uglavnom precizan sve dok se drži svojega predloška Orozija. Međutim, kod opisa zemljopisnoga položaja Istre čini se da ozbiljno griješi u određivanju strana svijeta. ${ }^{196} \mathrm{Za}$ autora AG-a Dalmacija se nalazi sjeverno od Ahaje; Jadran južno od Istre, Alpe zapadno od Istre, a pustoš (Panonija) između Karintije i Bugara, ponovno sjeverno od Istre. Upravo su uočeni "pomak" AG-a u odnosu na OR, smatrajući ga odrazom "novonastale situacije”, Sokolovi uzeli kao dokaz da je Alfredova Istra ustvari Dunav.

194 Matijević Sokol - Sokol, Hrvatska i Nin II, 21, govoreći o "avarskim desertama" navode: Einhard, Vita, 13 (16,5). Navod koji citiraju (deserta Boiorum) ranosrednjovjekovni autori mogli su načelno preuzeti od Plinija (Plinius, Naturalis historia, 3, 146; usp. i Strabo, Geographica, V, 1, 6 [213]; VII, 1, 5 [292], te Dimensuratio, 18); Annales Fuldenses i drugi anali na više mjesta spominju pustošenje Panonije (npr. AF. a. 884, a. 894 passim), no citirani navod iz Annales Iuvavenses nisam uspio pronaći. Reginonis Chronicon, a. 889, MGH, SSRG, 50, 131.

195 Bately, Old English Orosius, lxxxix, 171, dopušta mogućnost da spomen pustoši odražava suvremeno stanje u Panoniji izazvano franačko-moravskim sukobima.

196 O položaju Alfredovih strana svijeta vidi (s obilnom starijom literaturom): Malone, "King Alfred's North”, 139-167. 
No, kao što je izneseno, Katičić je takvo tumačenje odbacio, obezvrijedivši pojavu kao odraz Alfredove nepreciznosti (priznajući ipak da je to sitnica spram stvarnih nesklapnosti u drugim dijelovima teksta). ${ }^{197}$

Pitanje koje stoga valja postaviti jest: postoji li kakva "sustavnost greški” kod Alfredova odredivanja strana svijeta ili je njegov opis jednostavno zbrkan? Jedan od mogućih odgovora ponudio je K. Malone uočivši, na temelju odsječka AG-a koji spominje Istru i Bugare, da je sastavljač nemajući pred sobom predložak u Orozijevu tekstu s obzirom na Bugare - jednostavno “zalijepio” dva različita podatka: onaj o Bugarima u Meziji i Daciji na sjeveroistoku s podatkom o Istri na sjeverozapadu. Prema takvom tumačenju spojio ih je "na jedini moguć način” stapajući pod pojmom "sjever" (nordan) stvarni sjeveroistok i sjeverozapad. ${ }^{198}$ Uz određenu privlačnost takvoga jednostavnoga rješenja složenoga problema, valja upozoriti i na čitav niz srodnih greški glede određivanja strana svijeta u AG-u. Štoviše, uzmu li se u obzir i druga Maloneova opažanja o značenju strana svijeta za sastavljača toga spisa, bilo bi moguće govoriti upravo o sustavnoj pogrešci. Naime, Malone je došao do zaključka da je Alfred rabio "dva različita sustava orijentacije” koje je nazvao "klasičnim” (classical) i “pomaknutim” (shifted), iako se nije njima koristio dosljedno. ${ }^{199}$ Ključna osobina "pomaknutoga” sustava bio bi otklon "Alfredova sjevera" od $45^{\circ}$ u smjeru kazaljke na satu u odnosu na geografski sjever. ${ }^{200}$ Primjenjujući to tumačenje na razmatrane odnose, dobiva se slika prema kojoj je "Dalmacija sjeverozapadno od Ahaje, Jadran jugozapadno od Istre, Alpe sjeverozapadno od Istre, a pustoš (dio Panonije) između Karintije i Bugara ponovno sjeveroistočno od Istre”. ${ }^{201}$ Dakle, "Alfredov odmak" od otprilike $45^{\circ}$ u smjeru kazaljke na satu u odnosu na naše poimanje strana svijeta pokazuje se ne više kao plod zbrkanoga prenošenja podataka, već kao odraz sustavnoga određivanja strana svijeta. ${ }^{202}$

197 Katičić, "Dalmatia", 93.

198 Malone, “King Alfred's North", 150.

199 Isto, 166-167.

200 Važno je naglasiti da uočeni sustav ne odgovara svim dijelovima Alfredove Europe. Za kritku Maloneove pretpostavke vidi: Linderski, "Alfred the Great", 435-436, te temeljito opovrgavanje u: Michael Korhammer, "The orientation system in the Old English Orosius: Shifted or not?", u: Learning and Literature in Anglo-Saxon England, ed. Michael Lapidge - Helmut Gneuss, Cambridge 1985., 251-269. Valja međutim naglasiti da Korhammer ne uzima u obzir ovdje relevantne ulomke te da je njegova kritika usmjerena prvenstveno pobijanju teze o postojanju specifičnoga skandinavskoga sustava orijentacije.

201 Malone, "King Alfred's North”, 150.

202 Originalnost, ali i očita sustavnost Alfredova redoslijeda navođenja naroda i pokrajina odavno je uočena u literaturi. Usp. Edward D. Laborde, "King Alfred's System of Geographical Description in His Version of Orosius” (dalje: Laborde, “King Alfred's System”), The Geographical Journal, 62/2, 1923., 133-138. 
Upravo je uočavanje Alfredove sustavnosti važno za temeljito razumijevanje njegove "organizacije prostora" te joj vrijedi posvetiti još malo pažnje.

\section{3. Međusoban odnos pokrajina u Alfredovoj geografiji}

Prihvati li se tumačenje iz prethodnoga ulomka, u istome se svjetlu može protumačiti i drugi ulomak, u kojem Alfred spominje Bugare i Karintiju (AG, I, i, 4-5, 7-8):

Be supan him on opre healfe Donua pare ie is pat land Carendre sup op pa beorgas pe mon Alpis hat [...] be eastan Carendan londe, begeonda [n] pam westenne, is Pulgara land, 7 be eastan pam is Creca land..$^{203}$

Ulomak je prema uočenom počelu moguće prevesti (modificirajući Katičićev prijevod) kao:

“...i na jug (jugozapad) od sebe na drugoj strani rijeke Dunava jest zemlja Karantanija, na jug (jugozapad) sve do gorja koje se zove Alpe [...] Odatle na istok (jugoistok) od zemlje Karantanije, iza one pustoši jest zemlja Bugara. I na istok (jugoistok) od njih je zemlja Grka..."204

Prihvati li se ovakvo čitanje razmotrenoga ulomka i primijeni li se ono na ključni ulomak (AG I, i, 13-18) ${ }^{205}$, može se zaključiti da AG sadrži upravo precizan opis prostora između istočnih obronaka Alpa, Jadrana i Dunava. Slažući se u tome sa Sokolovima koji su upozorili na točnost AG-a upućujući pri tome i na stranu literaturu, na tragu iznesenih opažanja ipak nalazim pogrešnim zaključak da Alfred spominjući Istru, svjesno i s određenom nakanom pod tim imenom podrazumijeva Dunav. Drugim riječima, iako zaista ne bi bilo ispravno, kako kažu Sokolovi, "kategorički tvrditi (...) da je samo jedan oblik imena ispravan za jedan od ta dva zemljopisna pojma”, njihovo opažanje da "spominjanje jednog od imena za njih ne govori ništa, već samo opći kontekst u kojem se ti zemljopisni pojmovi nalaze” ne navodi nužno i na zaključak do kojega su oni

\footnotetext{
203 Bately, Old English Orosius, 13.

204. Katičić, "Dalmatia", 80. U tome kontekstu vrijedi upozoriti na činjenicu da Anonim Ravenjanin donosi podatak da su Bugari naseljeni "između Trakije ili Makedonije i Mezije" (Inter vero Tratiam vel Macedoniam et Mysiam inferiorem modo Bulgari habitant, qui ex super scripta Maiore Scythia egressi sunt. Anonymus, Cosmographia, IV, $6[185,3-6 / 48]$ ), no do ranoga 9. st. Bugari su svoju vlast proširili i nad znatnim dijelom jugoistočnoga ugla Panonije.

205 Bately, Old English Orosius, 18.
} 
došli. ${ }^{206}$ Naime, mišljenje da uporaba jednoga ili drugoga imena za Dunav teško da može dokazati na koji se dio Dunava odnosi navod sasvim je prihvatljivo, no upravo "opći kontekst" uporabe pojma Istria na koji se pozivaju ne dopušta protumačiti taj pojam kao Ister tj. prostor Podunavlja. ${ }^{207}$ Kako, naime, objasniti, s jedne strane, izjednačavanje Istre s Dunavom (u kontekstu postojanja franačke "novostečene pokrajine uz Dunav-Istriu istočno od Regensburga, do iza Beča”"08), a s druge strane, tumačenje podatka o pustoši (koja se prema AG-u nalazi "sjeverno od Istre” (ond be nordan pat westen) ${ }^{209}$ kao Panoniji “između Alpa, Blatnog jezera i Dunava"210? Pogrešno tumačenje proizišlo je, između ostaloga, iz, čini se pogrešnoga, smještanja pustoši “sjeverno (od Hrvatske)” umjesto sjeverno od Istre. Ispravnim čitanjem navedenoga mjesta može se utvrditi da prevođenje pojma Istria Dunavom ili Podunavljem nema uporišta u AG-u, kao uostalom ni u drugim vrelima.

Vraćajući se pak opažanju o sustavnosti AG-a, geografsku viziju njezina autora moguće je pregledno prikazati oslanjajući se na uočavanje njegove uporabe "osnovnih točaka” (E. D. Laborde ih naziva pivotal points) u čemu on, slijedeći OR, kreativno primjenjuje model na prostore i narode o kojima klasična geografija ne donosi podatke. ${ }^{211}$ Pri usporedbi dvaju opisa važno je podsjetiti i na činjenicu da je u opisu Europe južno od Dunava Orozije (OR, I, ii, 54-60) kao orijentacijske točke rabio (pojedinačno) rimske pokrajine Meziju, Trakiju, Makedoniju, Ahaju i Dalmaciju (te kao jednu cjelinu skupinu Pannonia-Noricum-Raetia), za razliku od autora AG-a koji ih je sve "sažeo”, zadržavajući tek tri točke očito značajne u njegovo doba: Carigrad, Istru i Dalmaciju. ${ }^{212}$ Razmotrivši međusobne odnose pokrajina u "Alfredovu" opisu zemalja između Alpa, Dunava i Jadrana može se potvrditi mišljenje J. Bately da su, u odnosu na OR, autorove pro-

\footnotetext{
206 Matijević Sokol - Sokol, Hrvatska i Nin II, 26.

207 Isto, 20. Priloženi zemljovid implicira da bi se radilo o prostoru Srijema.

208 Isto, 29.

209 AG, I, i, 17-18 (Bately, Old English Orosius, 18.). Važno je naglasiti da se u navedenom ulomku radi o orijentaciji u odnosu na Istru, a ne, kao što su preveli Sokolovi, u odnosu na Dalmaciju. Katičićev prijevod "i na sjever je ona pustoš koja je između Karantanije i Bugara" dopuštao bi oba tumačenja, no u kontekstu Alfredova sustava nabrajanja nema dvojbe da AG pustoš smješta sjeverno od Istre. Usp. Bately, Old English Orosius, 202.

210 Matijević Sokol - Sokol, Hrvatska i Nin II, 21. Usp. i bilj. 189.

211 Usp. Laborde, “King Alfred's System”, 133-138.

212 Bately, Old English Orosius, 200 (usp. "Introduction”, u: Bately, Old English Orosius, lxix), primjećujući da je teško zamisliti kako bi "ukoliko je zaista (kurziv T. V.) podatke preuzeo od Orozija to učinio ne nacrtavši zemljovid ili plan tog područja”.
} 
mjene "toliko radikalne da je moguće smatrati da je čitav odlomak promijenjen kako bi odgovarao, uz nešto iznimki, situaciji 9. st." ${ }^{13} \mathrm{Na}$ tragu njezina drugoga opažanja da je takvo viđenje autor AG-a mogao preuzeti iz drugoga "neposrednog izvora”, zasad je nemoguće odgovoriti na pitanje o kojem je izvoru (ili izvorima) riječ. Moguće je, međutim, potvrditi pretpostavku da se autor AG-a, uz nepoznati izvor suvremenih podataka, pri uporabi klasičnog zemljopisnog pojmovlja nije koristio isključivo OR-om već, u najmanju ruku, nekolicinom starijih tekstova poput Divisio orbis terrarum (u to vrijeme pripisivane sv. Jeronimu) i Izidorovih Etimologija. ${ }^{214}$ Uz nužnost pozornijega tumačenja Alfredove geografije upravo u svjetlu sadržaja tih tekstova, pitanje drugih, još uvijek neidentificiranih, izvora AG-a ostaje i dalje otvoreno podsjećajući na važnost temeljitoga izučavanja tekstova dostupnih (pa i moguće dostupnih) sastavljaču toga staroengleskoga teksta.

Bez obzira na ishod daljega proučavanja AG-a, nalazim da ovdje iznesena opažanja dodatno upućuju na neodrživost "geografskoga argumenta" prema kojem se "Alfredova Istra" - navodni Dunav - nalazi negdje u Podunavlju. U tome sam smislu uvjeren da se valja složiti s Katičićevim zaključkom da se u konkretnom ulomku AG-a "Dunav u vezi s opisom Dalmacije uopće ne spominje”. Međutim, donekle nasuprot njegovu mišljenju, čini se očitim da pojam Istria u AG-u ne odgovara u potpunosti ni shvaćanju prema kojem je Istra isključivo sjevernojadranski poluotok. Naime, kako se čini, opis "Alfredove Istre" ne podudara se s klasičnim administrativnim (kao ni autoru AG-a suvremenim) prostorom Istre umnogome podsjećajući na "iskrivljenu” percepciju mnogih njegovih prethodnika, suvremenika te, osobito, kasnijih geografa. Razmotrivši dosad izvore koji su poslužili (ili mogli poslužiti) oblikovanju "mentalne slike” istočnoalpsko-panonskoga prostora, u posljednjoj bismo cjelini ovoga članka pažnju željeli usmjeriti na nekoliko mlađih primjera vizualizacije zemljopisnoga znanja u obliku "svjetskih zemljovida".

213 Ista, "The relationship", 52. 


\section{Srednjovjekovna kartografija kao "iskrivljujuće ogledalo antičke geografije"}

Procvat istraživanja (rano)srednjovjekovne kartografije može se zahvaliti revoluciji koja se dogodila u tom području tijekom posljednjih desetljeća. ${ }^{215}$ Temeljita promjena u shvaćanju svrhe i smisla ranosrednjovjekovne kartografije dovela je do toga da se zemljovidi i njihovi opisi ne smatraju više tek bijednim prethodnicima prave kartografije, već zanimljivim i vrijednim izvorima sui generis. U kontekstu ove rasprave na značaj kartografskih izvora upozorili su Sokolovi oslonivši se u svojem tekstu na reprodukcije dvaju (rano)srednjovjekovnih zemljovida, tzv. Cottoniane i Zemljovida Lamberta $i$ s St. Omera. ${ }^{216}$ Općenito uzevši, rani srednjovjekovni zemljovidi spadaju u kategoriju izvora koja tek iščekuje temeljitiju raščlambu u hrvatskoj historiografiji. ${ }^{217}$ Međutim, bez nakane upuštanja u takav pothvat, razmotrit ću ovdje nekoliko odabranih "svjetskih zemljovida” nastalih između 8. i 12. st. ${ }^{218}$ Izraz mappa mundi (lat. "tkanina svijeta”) javio se već u ranome 9. st., no u potpunosti se uvriježio kao terminus technicus za zemljovide koji prikazuju “čitav svijet” (bilo da su zaista naslikani na tkanini ili ne) tek tijekom 12. i 13. st. ${ }^{219}$ Donekle zbunjujuća činjenica da najveći broj sačuvanih mappae mundi potječe iz Engleske uglavnom se tumačila time da je u Engleskoj vjerojatno već u ranome srednjem vijeku postojao velik broj sačuvanih rimskih "svjetskih zemljovida". ${ }^{20}$

215 Ne implicirajući time kompetenciju u brzo rastućem polju povijesnokartografskih istraživanja, upućujem tek na nekoliko studija koje lijepo odražavaju oblikovanje nove "kartografske paradigme": Evelyn Edson, Mapping time and space: how medieval mapmakers viewed their world, London 1997.; Paul Dean Adshead Harvey, Mappa Mundi: The Hereford World Map (dalje: Harvey, Mappa Mundi), Toronto - Buffalo 1996.; Natalia Lozovsky, The earth is our book, Ann Arbor 2000.

216 Prema: Mirela Slukan Altić, Povijesna kartografija: kartografski izvori u povijesnim znanostima (dalje: Slukan Altić, Povijesna kartografija), Samobor 2003., 85. Zemljovidi su navedeni kao prilog pretpostavci o "postojanju novostečene pokrajine uz Dunav-Istriu istočno od Regensburga, do iza Beča”. Matijević Sokol - Sokol, Hrvatska i Nin II, 29-30.

217 Usp. Slukan Altić, Povijesna kartografija, passim.

218 Za potrebe ove rasprave odabrano je nekoliko (inače poznatih) zemljovida čije su reprodukcije priložene prvenstveno radi ilustracije njihova izgleda. Želeći za potrebe ove rasprave približiti pojedine detalje, priredio sam crteže koji vjerno čuvaju proporcije i odnose među slikovnim elementima na izvornim prikazima. Tekstualni dijelovi zemljovida također su, prvenstveno radi preglednosti i čitljivosti, računalno transkribirani i uneseni u crteže.

219 Patrick Dalché, La 'Description mappe mundi' de Hugues de Saint-Victor, Paris 1988., 92-93.

220 Harvey, Mappa Mundi, 26. 


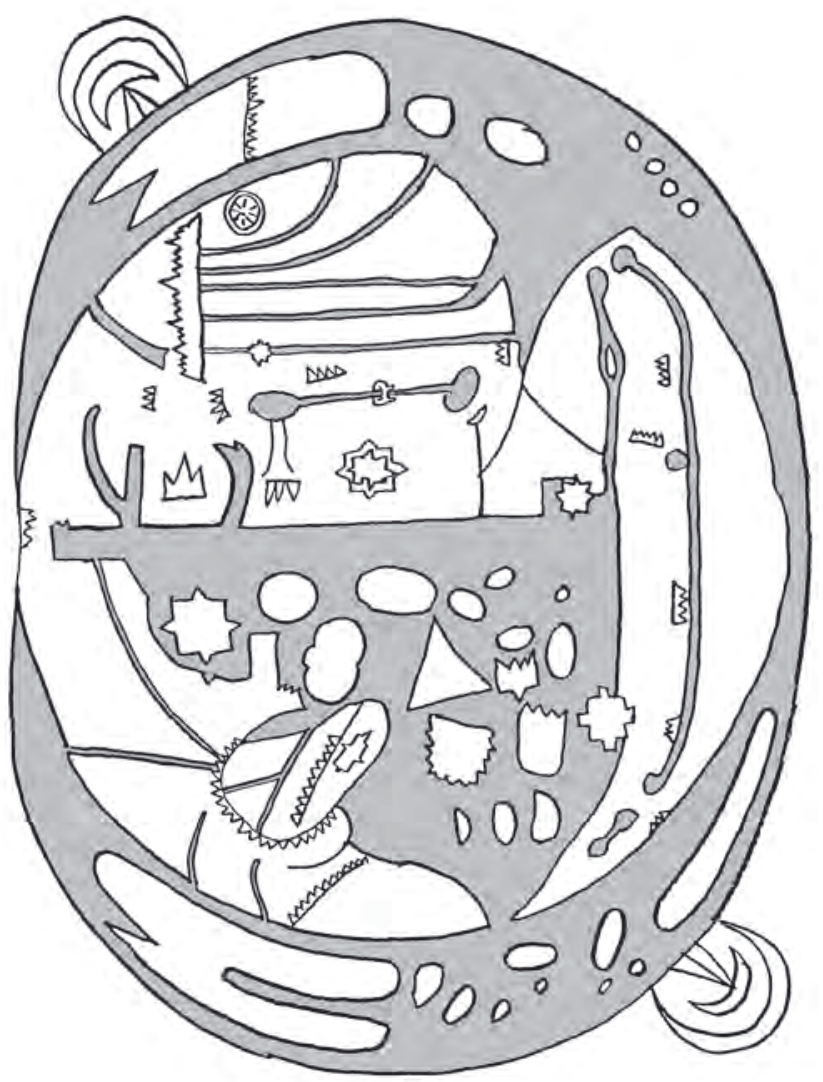

S1. 1. Vatikanska mappa mundi, Cod. Vat. Lat. 6018

\section{Vatikanska mappa mundi (8./9. st.)}

Mappa mundi iz Vatikanske knjižnice ${ }^{221}$ jedan je od starijih sačuvanih srednjovjekovnih zemljovida. Zemljovid se nalazi u rukopisu Izidorovih Etimologija i prema modernim izdavačima postanak mu je moguće smjestiti u kasno 8. ili 9. st. ${ }^{222}$ Iako najnovija istraživanja obeskrjepljuju stariju pretpostavku o tome da je zemljovid bio sastavljen kao ilustracija Etimologijama, ${ }^{223}$ vrlo rana datacija u kombinaciji s neobičnom geografskom vizijom prostora između Dunava i Jadrana čine ga zanimljivim predmetom razmatranja. Pri-

221 Mappa mundi, Cod. Vat. Lat. 6018, fols. 63v-64r.

222 Itineraria, 456. Jedan od prvih istraživača toga zemljovida, Richard Uhden, smjestio je njegov nastanak oko 775. John Williams, "Isidore, Orosius and the Beatus Map" (dalje: Williams, "Isidore"), Imago Mundi, 49, 1997., 15 .

223 Williams, "Isidore”, 15, 26. Više je autora smatralo Mappa mundi, Cod. Vat. Lat. 6018, dijelom "izidorovske tradicije" povezane sa skupinom zemljovida tzv. "tipa Beatus" (prema redovniku Beatu iz Libeane, sastavljaču poznatih Komentara knjige Otkrivenja [776.] čiji je tekst, sačuvan u većem broju rukopisa, bio u čak 14 prijepisa popraćen zemljovidima), što je u novije vrijeme dovedeno u pitanje. Usp. Williams, "Isidore", 7-15 i dalje. 
kaz dijela Europe zanimljiv za ovu raspravu donosi ključne odredišne točke starijih geografija: Danubius se proteže od prostora na spoju Italije i Panonije, a dijeli rimske pokrajine Panoniju, Dardaniju, Dalmaciju, Istru i Makedoniju od "barbarskih pokrajina” s druge strane. Dva nam se detalja ovdje čine osobito značajnima: Istra nije prikazana kao dio Italije, već je (iako se nalazi na istočnoj obali Jadrana) povezana s Trakijom “potiskujući” Dardaniju i Dalmaciju dublje u unutrašnjost. Slična zbrka (očito karakteristična za zemljovide nastale s osloncem na Izidorove Etimologïe i srodne tekstove) uočljiva je i na nizu mappae mundi nastalih tijekom idućih stoljeća.

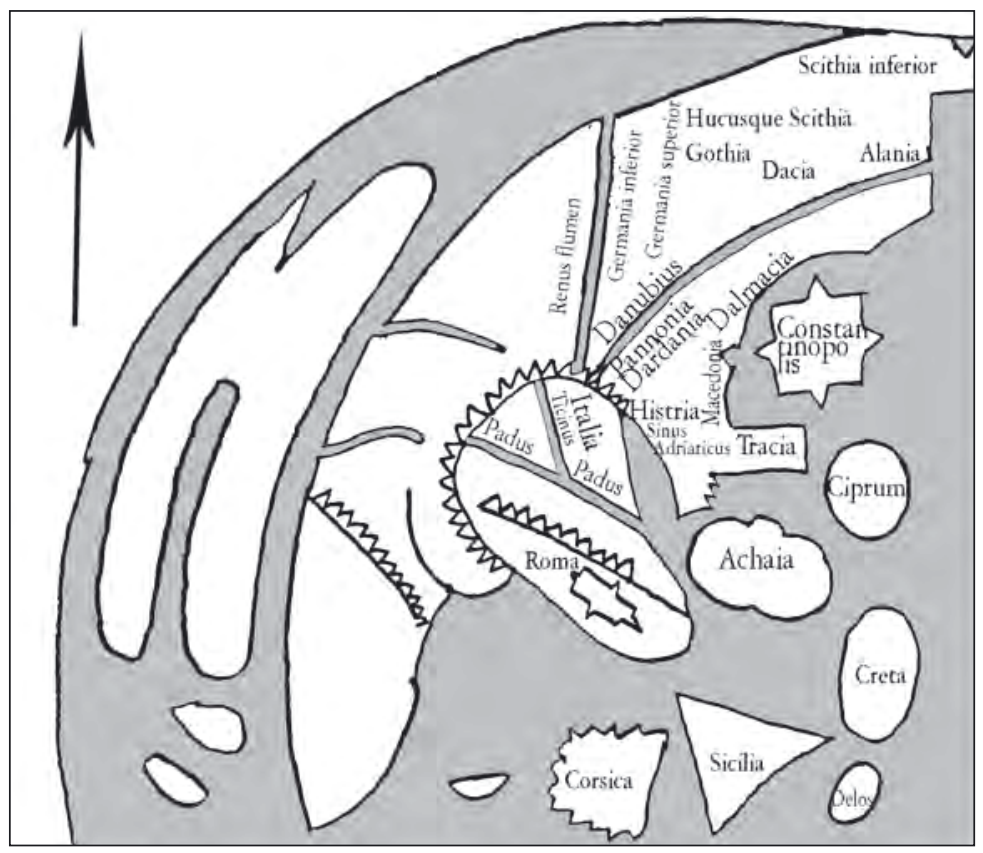

S1. 2. Vatikanska mappa mundi, detalj

\section{Cottonov zemljovid (10. - 11. st.)}

Rana mappa mundi poznata pod imenom Cottonov zemljovid (Cottoniana, Cotton map), u literaturi često nazivana i Anglosaski zemljovid (AngloSaxon map), dobila je ime prema nekadašnjem vlasniku kolekcije rukopisa Sir Robertu Cottonu (1571. - 1631.), a danas se nalazi u londonskoj British Library. ${ }^{224}$ Taj je zemljovid nastao prema nekim autorima sredinom 10. st., 
dok ga drugi datiraju drugom četvrtinom 11. st. ${ }^{225}$ Cotton je bio pridružen kao nadopuna rukopisu latinskoga prijevoda Priscijanove Periegeze. ${ }^{226}$ Pretpostavlja se da je nastao u Canterburyju na temelju predloška starije rimske geografije, sukcesivno nadopunjavane novim spoznajama tijekom 9. i 10. st. Miješanje tih različitih slojeva geografskoga znanja zaslužno je za uvelike zbrkanu sliku srednjoeuropskoga prostora. Bez obzira na gotovo zastrašujuću netočnost prikaza odnosa pojedinih nekadašnjih rimskih provincija, Anglosaski zemljovid svjedoči o kontinuitetu uporabe rimske terminologije i provincijskim granicama (označenim ravnim linijama), čime pokazuje svoje podrijetlo u antičkoj geografiji. S druge strane, mnoštvo podataka čini ga vrijednim izvorom za širenje geografskoga znanja o "novim narodima” u srednjoj i istočnoj Europi.

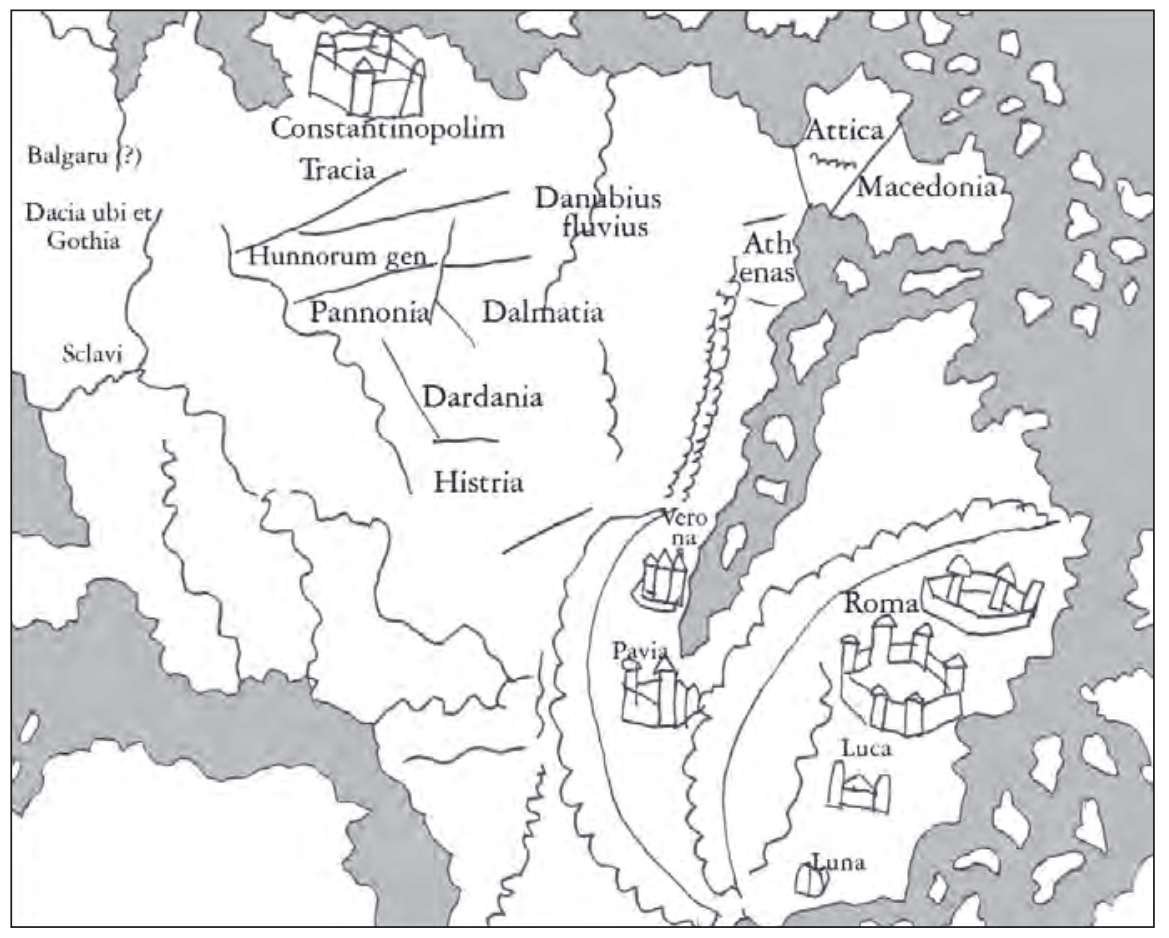

Sl. 3. Cottonov zemljovid, British Library, Cotton MS. Tiberius B.V., fol. 56v., detalj

225 David Woodward, “Medieval Mappaemundi", u: The history of cartography, vol 1.: John Brian Harley - David Woodward (ed.), Cartography in prehistoric, ancient and medieval Europe and the Mediterranean, Chicago London 1987., 361; Harvey, Mappa Mundi, 26. Slukan Altić, Povijesna kartografija, 85, i Matijević Sokol

- Sokol, Hrvatska $i$ Nin II, 30, pogrešno je datiraju u 9. st. 
Što se ovdje razmatranih problema tiče, najuočljivija osobina toga zemljovida jest da prikazuje Istru kao prostrano područje smješteno (neposredno) zapadno od Dardanije i ostalih iliričkih pokrajina. Južno od Istre nalaze se planine koje ju odvajaju od Jadranskoga mora. Na mjestu gdje bismo očekivali “stvarnu Istru”, dakle na sjeveroistočnoj obali Jadrana nalazi se grad Verona, planinskim lancem odvojena od ostatka istočne jadranske obale. Istru sa sjevera omeđuje rijeka koja teče prema istoku dijeleći prostor sa svoje južne strane (od zapada prema istoku: Histria-Pannonia-Hunorum gen[s/tes?] - Tracia) od krajeva sa sjeverne strane (od zapada prema istoku: Sclavi-Dacia ubi et Gothia - Balgaru [?]). Prema položaju ta bi “dvokraka” rijeka morala biti Dunav, no dunavskim je imenom (Danubius fluvius) označena druga rijeka koja teče na istok od Dalmacije i ulijeva se u more između Carigrada i Ahaje (Attica).

\section{Zemljovid Gvidona Pizanca (11./12. st.)}

Među starijima i, za ovu raspravu, zanimljivim mappae mundi svakako je ona s početka 12. st. pripisana Pizancu Gvidonu, sačuvana uz njegov spis Liber de varïs historïs. Prema najnovijim istraživanjima autor Geografije bio je pizanski klerik koji je živio krajem 11. i početkom 12. st. ${ }^{227}$ Gvidonova kompilacija sačuvana je u više redakcija, od kojih je najstarija i najpotpunija sačuvana u rukopisu koji se danas nalazi u Bibliothèque Royale u Bruxellesu. ${ }^{228}$ Nastanak spisa (i pridruženoga mu zemljovida) datira se, prema autorovu Prologu, 1119. godinom. Za ovu je raspravu važna činjenica da Gvidon, opisujući Italiju i krajeve njoj na istok, uz druge brojne starije rimske autore, očito obilato rabi djelo Ravenskog Geografa, Orozijevu Povijest te Izidorove Etimologije. ${ }^{229}$

Promatrajući tekstualni dio Gvidonove zemljopisne vizije, može se reći da je on, poput njegova glavnoga predloška Ravenskog Geografa, uglavnom uravnotežen i realističan kad se radi o krajevima sjevernoga Jadrana. Istru Gvidon spominje na više mjesta donoseći prilično točan opis njezina

227 Detaljnije o Gvidonovu životu i karijeri vidi u: Michele Campopiano, "Introduzione”, u: Michele Campopiano (ed.), Liber Guidonis compositus de variis Historiis, Firenze 2008., LI-LXII.

228 Bibliotheque Royale Albert Ier, MS. 3897-3919 (cat. 3095), fol. 53v. Latinski tekst preuzet je iz dva izdanja: Ravennatis anonymi cosmographia et Gvidonis geographica, ed. Moritz Eduard Pinder et Gustav Parthey, Berolini 1860., i Ravennatis Anonymi Cosmographia et Guidonis Geographica, ed. Joseph Schnetz, u: Itineraria Romana, II, Lipsiae 1940., 113-142 (dalje: Guido, Geographica). Navodi se odnose na broj odlomka te (u zagradi) broj stranica u berlinskom/leipziškom izdanju. Potpuno (novije) izdanje Gvidonova djela još nije priređeno te se zasada rabe starija izdanja, poput navedenoga berlinskoga ili noviji izvadci koje su priredili J. Schnetz i M. Campopiano.

229 Harley, The History of Cartography, 1, 327-328, 348, 350. 


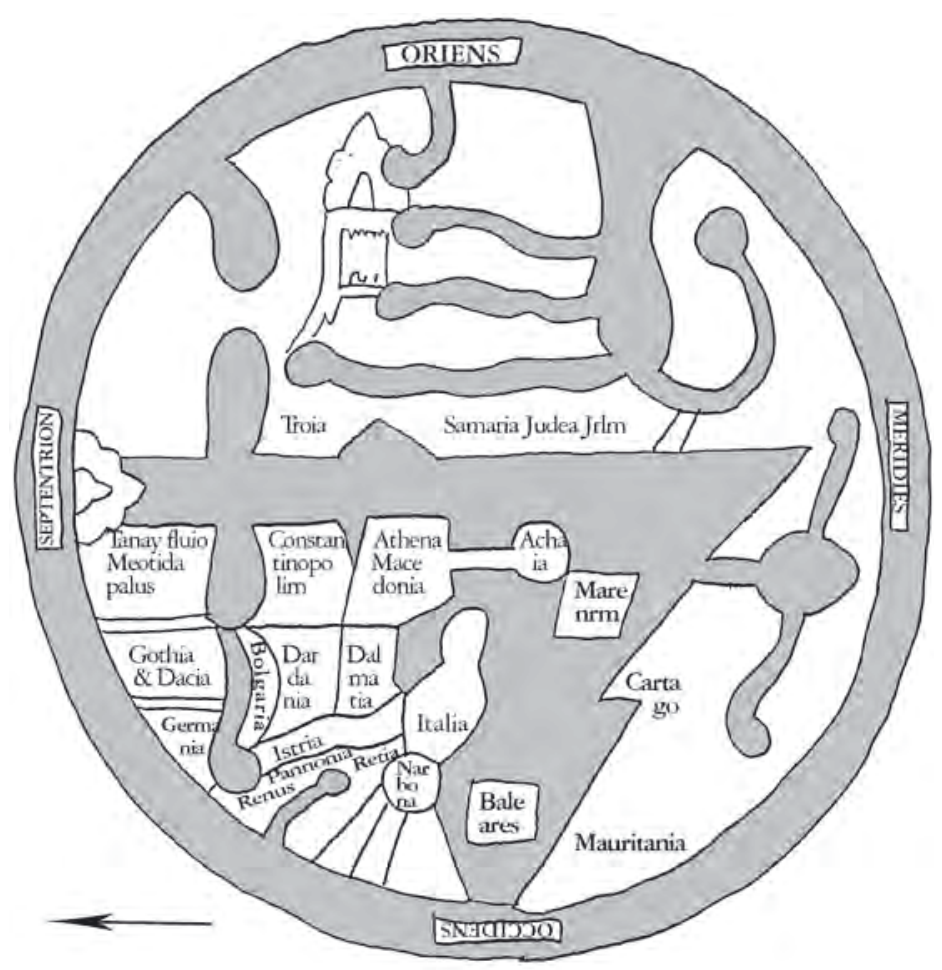

S1. 4. Gvidonov zemljovid, Bibliothèque Royale Albert I ${ }^{\mathrm{er}}$, MS. 3897-3919, fol. 53v.

položaja ${ }^{230}$ te popis njezinih gradova ${ }^{231}$. Na nekoliko mjesta ipak donosi zbunjujuće podatke, poput onoga gdje Istru povezuje s Neustrijom ${ }^{232}$. Začudo, Dunav u tekstu spominje tek jednom, pišući o rijeci Apion koja teče ad Danubium. ${ }^{233}$ Međutim, kod Gvidona je, od njegova tekstualnoga opisa u ovome kontekstu mnogo značajniji spomenuti zemljovid. Taj je zemljovid, klasificiran kao tip “izidorovskih" mappae mundi, bio nesumnjivo izrađen kao ilustracija uz autorov tekst.

Gvidonovo viđenje odnosa Istre, izvora Dunava, Panonije i Dalmacije pruža upravo lijep primjer kako je netko u ranome srednjem vijeku mogao razumjeti geografiju Orozijeve Povijesti ili Izidorovih Etimologija. Zaokrenemo li zemljovid za $45^{\circ}$ (v. sl. 5) uočavamo da je Dalmatia ispravno smještena sjeverno od Jadrana. Iznad nje se nalazi Dardania koja je polukružnom

230 Guido, Geographica, 6 (453,19-454,3 / 114): A secundo latere est Italie finis per litora predicti sinus maris Adriatici usque ad expletum tractum totius provincie Histrie.

231 Za širi popis gradova Venecije i Istre vidi: Guido, Geographica, 17-20 (459,13-462,6 / 116).

232 Guido, Geographica, 66 (501,13-14 / 128): Secunda Histria cum Neustria, quae Venetiarum antiqua dignoscitur. 233 Guido, Geographica, 126 (553,3 / 141). 
linijom odijeljena od prostora koji autor naziva Bolgaria. "Crvoliki” simbol koji očito prikazuje Dunav upućuje promatrača na zaključak da on izvire sjeverno od Panonije, u blizini rijeke Rajne (Renus). Istria je, prema Gvidonu, izdužena i "valovita” pokrajina rastegnuta u smjeru sjever-jug. Od Panonije (koja je povezana s Recijom) dijeli je izvijena linija za koju je teško odrediti predstavlja li kakvu manju rijeku (velike rijeke poput Dunava, Rajne, Nila ili Tigrisa označene su "crvolikim” simbolom) ili granicu među pokrajinama (većina granica među rimskim provincijama označena je ravnim linijama). U svakome slučaju, vjerojatno najzanimljiviji detalj na Gvidonovu zemljovidu jest njegovo povezivanje Istre i Bugarske što, uz ostale naznake o Gvidonovim klasičnim predlošcima, upućuje i na zanimljivu srodnost njegove vizije s AG-om.

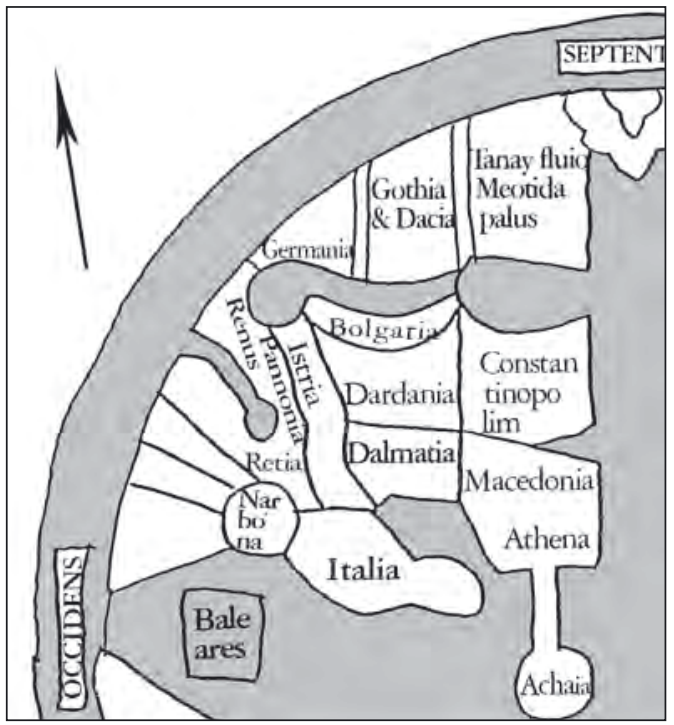

Sl. 5. Gvidonov zemljovid, detalj

\section{Mappa mundi Lamberta iz Saint-Omera (o. 1120.)}

Autorom toga zanimljivoga zemljovida smatra se Lambert iz Saint-Omera (o. 1060. - o. 1150.), sastavljač enciklopedije poznate pod imenom Liber Floridus. Prema kronici pridodanoj toj kompilaciji izrada više zemljovida datira se obično 1119. (tj. prije 1125.). Zemljovid koji je ovdje predmet interesa sačuvan je u trima varijantama koje se, prema mjestu čuvanja, navode kao Ghent, Wolfenbüttel i Paris. Zemljovid sačuvan u gentskom rukopisu smatra 


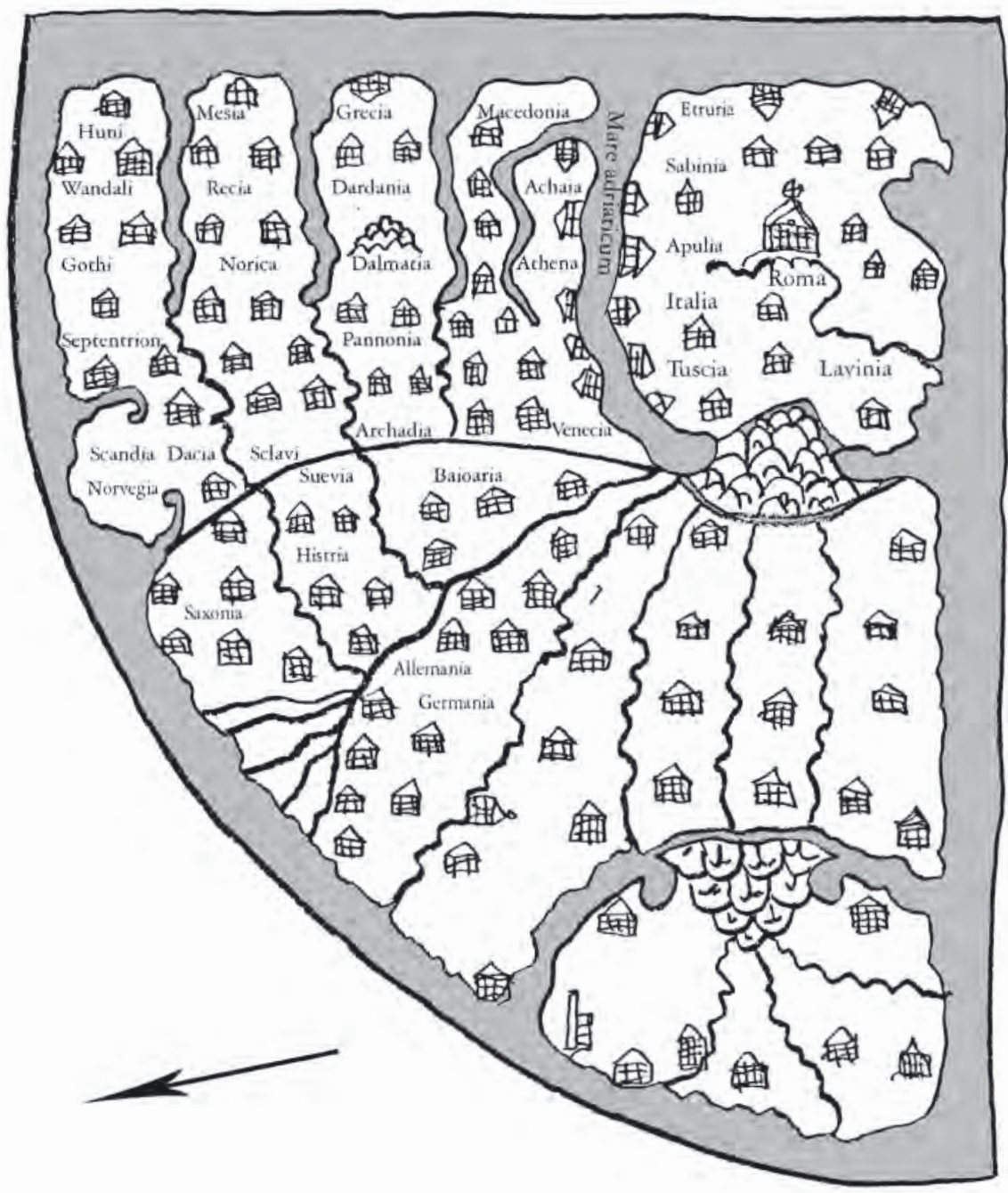

S1. 6. Mappa mundi Lamberta iz Saint-Omera, Gent, Universiteitsbibliotheek, Ms. 92, f. 241r

se najstarijim ${ }^{234}$ i, iako se naziva mappa mundi, prikazuje samo Europu. Smatra se da je autor zemljovida sam kompilator. Za ovu raspravu zemljovid iz Liber Floridus je zanimljiv jer, usprkos svojoj shematičnosti i očitoj netočnosti, upućuje na percepciju europskoga prostora u kojem Istra nije povezana s Jadranom, već s gornjim tokom Dunava - otprilike u smislu koji pojmu pridaju Sokolovi. 
Zaokrene li se Lambertov zemljovid za $45^{\circ}$, dobiva se sljedeća slika:

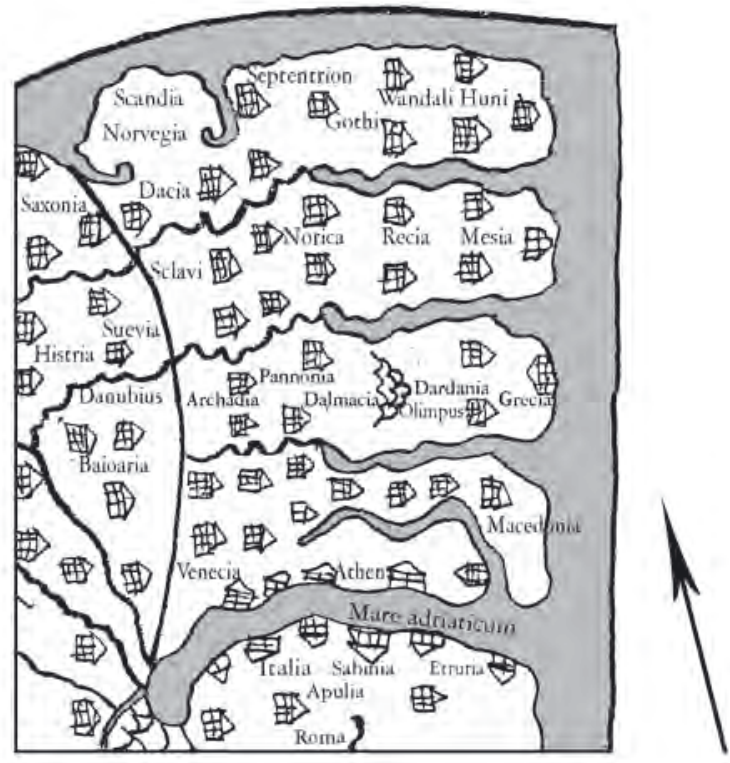

Sl. 7. Mappa mundi Lamberta iz Saint-Omera, detalj

\section{Zemljovid Henrika iz Mainza ili Zemljovid iz Sawleya (o. 1200.)}

Naziv je rezultat nesporazuma: zemljovid nema veze ni s kakvim Henrikom, a nastao je krajem 12. ili početkom 13. st. (iako ima autora koji mu kao vrijeme nastanka određuju rano 12. st.) $)^{235}$ u Engleskoj, vjerojatno u Durhamu, odakle je prešao u posjed cistercitske opatije Sawley u Yorkshireu. ${ }^{236}$ Pretpostavlja se da je nastao prema starijem i većem predlošku iz 11. st. Također se smatra da je zemljovid povezan s tzv. Herefordskim zemljovidom, a danas se čuva u Cambridgeu. ${ }^{237} \mathrm{Za}$ ovu je raspravu osobito važan zbog detaljnoga i neobičnoga prikaza Istre.

Sawley je poput većine mappae mundi orijentiran prema istoku, no u njegovom središtu nije Jeruzalem, već Cikladsko otočje. Jadransko more (Mare veneticum), neproporcionalno smanjeno u odnosu na kopno s obiju strana, položeno je u smjeru SZ - JI. Na istočnoj obali stoji oznaka grada, no bez naziva. Dublje u unutrašnjosti označen je Illiricus, na jugoistok od kojega se nalaze Corinthus i Achaya. Najzanimljiviji detalj svakako je rijeka koja

\footnotetext{
235 Woodward, "Medieval Mappaemundi", 361, datira ga 1110. god.

236 Općenito o zemljovidu vidi u: Paul Dean Adshead Harvey, "The Sawley Map and Other World Maps in

Twelfth-Century England", Imago Mundi, 49, 1997., 33-42.

237 Henry of Mainz world map (saec. XII), Cambridge, Corpus Christi College, MS. 66, p. 2.
} 
izvire u planinama sjeverozapadno od jadranskoga zaljeva i koju je autor zemljovida označio kao $f[$ umen/uvius?] Hister. Položaj izvora upućivao bi na izvor rijeke Save negdje u današnjoj Sloveniji. O identitetu rijeke govore i sljedeći detalji: paralelno s tim Histrom, njemu sa sjeverne strane, teče rijeka označena imenom Draua. Prostor uz Hister autor je označio imenom Histria. Okvirna točnost prikaza dijela prostora istočno od Alpa ocrtava se smještanjem grada Sabarria (!) $c$ [ivitas $s[$ ancti $]$ Martini, Drave i Dunava (Danubius) istočno od Norika. Danubius izvire iz neimenovane planine dijeleći Alemaniju od Recije. Neimenovani “južni pritok” Dunava dijeli pak dvije Recije (sjeverna Retia maior i južna Retia minor), od kojih je druga odijeljena od Norika (Noricus) oznakom granice provincija. Danubius teče prema Crnome moru dijeleći pokrajine sa svoje južne strane (Pannonia - Mesia) od onih sa sjeverne strane (Sarmathe - Tracia et Russia [?]). Zanimljivo je da se Hister, čije porječje s južne strane kartograf, kao što je spomenuto, naziva Histria - usprkos općem prostornom neskladu zemljovida (blizina ušća u Crno more) - ulijeva u Dunav na mjestu gdje se sastaju Pannonia i Mesia.

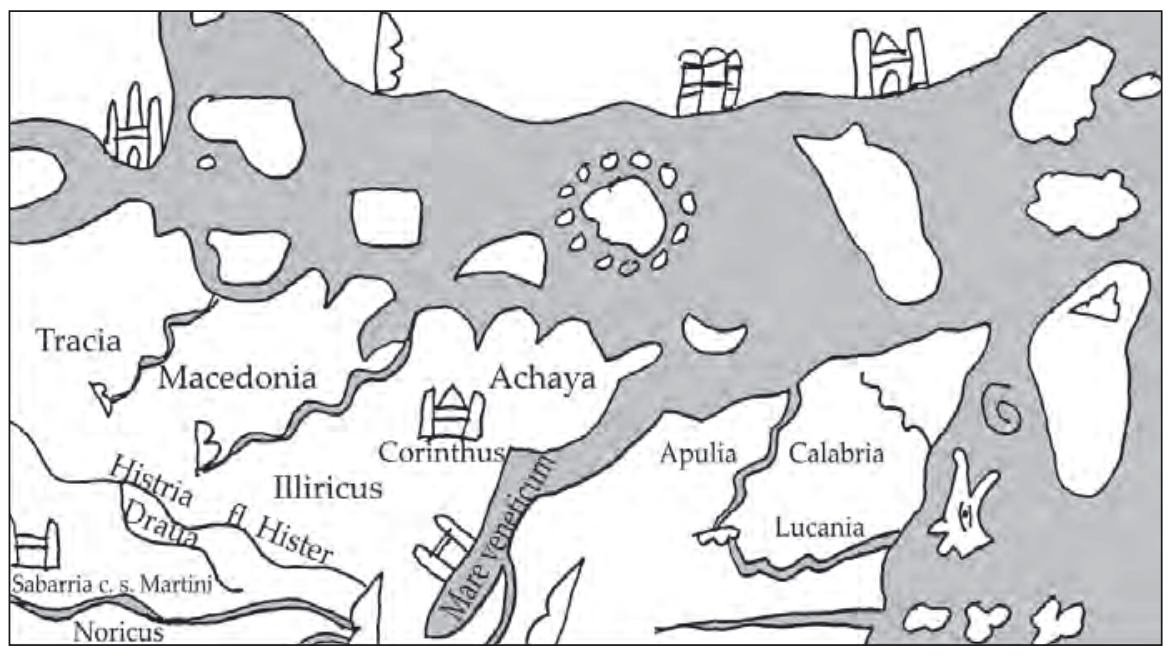

S1. 8. Zemljovid Henrika iz Mainza, Cambridge, Corpus Christi College, MS. 66, p. 2, detalj

\section{Jeronimov zemljovid Azije (o. 1150.), Ebstorfska mappa mundi (13. st.) i Herefordski zemljovid (kasno 13. st.)}

Posljednja tri zemljovida na koje bih želio tek ukratko uputiti kronološki uvelike izlaze iz zamišljenoga okvira, no smatram ih zanimljivim za usporedbu prvenstveno zbog nekoliko neobičnih detalja koji svjedoče o razno- 
likosti percepcije razmatranoga prostora prije pojave preciznijih tipova zemljovida u kasnome srednjem vijeku.

Tzv. Jeronimov zemljovid Azije bio je pridružen djelima sv. Jeronima u rukopisu iz opatije St. Martin kraj Tournaia te ga se pogrešno pripisivalo sv. Jeronimu. ${ }^{238}$ Smatra se srodnim Herefordskoj mappa mundi, ${ }^{239}$ a danas se, poput Anglosaskog zemljovida, nalazi u londonskoj British Library. ${ }^{240}$ Najveći dio zemljovida prikazuje “Aziju”, dok je "Europi” posvećen znatno manji prostor i manje pažnje. Jeronimov zemljovid, usprkos zbrkanosti i činjenici da Istru uopće ne spominje, zanimljiv je u usporedbi s prethodnim zemljovidima jer donosi donekle sličan redoslijed pojmova smještenih uz Dunav (koji naziva Danuvius ut Hister): Sabaria c[ivitas] - Pannonia Sirmium c[ivitas] Mesia hoc et Vulgaria. Inače, uz sjevernu obalu Jadrana nalazi se Illiricus koji Salona c[ivitas $]$ dijeli od Dalmacije.

Ebstorfska mappa mundi (vrlo često uspoređivana sa srodnim Herefordskim zemljovidom) nosi ime prema Ebstorfu u okolici Lüneburga u današnjoj sjevernoj Njemačkoj. Obično se datira u 1239., premda bi je se, na temelju raščlambe stila i rukopisa, moglo smjestiti i u kasno 13. st. Moguće je da se radi o prijepisu ranije sastavljenoga zemljovida. Ebstorfska mappa mundi bila je uništena tijekom bombardiranja Hannovera 1943. te su danas dostupni tek prikazi rekonstrukcije napravljene na temelju starijih reprodukcija. ${ }^{241}$ Među srodnim (i vrlo kasnim primjerima) mappae mundi ovaj se zemljovid ističe svojom upravo nevjerojatnom zbrkanošću. Iako donosi velik broj podataka, geografski položaj naselja, rijeka i pokrajina toliko je izmiješan da je vrlo teško uspostaviti ikakav sustav. Poput srodnoga Herefordskog zemljovida, i Ebstorfski čuva čitav niz antičkih imena izjednačavajući naselja poput npr. Siska sa suvremenim gradovima.

Herefordski zemljovid dospio je u katedralu u Herefordu oko 1300. godine, vjerojatno u vezi s aktivnošću biskupa Rikarda Swinfielda (1283. - 1317.). ${ }^{242}$ Autorom se obično smatra Rikard iz Holdinghama ili Rikard de Bello te se obično datira krajem 13. st. ${ }^{243}$ Zemljovid ovdje navodimo kao izu-

238 U tome smislu i: Slukan Altić, Povijesna kartografija, 85. Na istome mjestu opisan zemljovid prikazan na sljedećoj stranici kao "Beatusova karta svijeta iz 8. stoljeća" navodi na pogrešan zaključak da se radi o najstarijem srednjovjekovnom zemljovidu. Riječ je zapravo o tzv. "Beatu iz Saint-Severa”, zemljovidu sačuvanom u pariškom rukopisu (BNF, MS Lat. 8878 , fols. 45bisv - 45ter) iz 12. st.

239 Harvey, Mappa Mundi, 14.

240 Jerome map of Asia (saec. XII), British Library, Additional MS, 10049, f. 64 .

241 Harvey, Mappa Mundi, 33.

242 Isto, 14

243 Woodward, "Medieval Mappaemundi", 363. 
zetno kasni primjer koji upućuje na to da autor Istru doživljava kao prostor koji graniči s Ilirikom (u kojem je naznačen Sisak).

Razmotrivši u posljednjem odlomku prikazane zemljovide, opažanju M. Križmana da su "uzalud zemljopisac Strabon i polihistor Plinije Stariji dokazivali da su Grci taj odvojak (Dunava) izmislili; predaja se o njemu knjiški nastavljala čak do Izidora Seviljskoga”"244 može se pouzdano pridodati još barem nekoliko stoljeća. Stare su antičke kontaminacije, u raznim inačicama, nastajale, nestajale i ponovno uskrsavale još stoljećima nakon što su ih Strabon, Plinije i njihovi nastavljači odbacili. Za ovu je raspravu to osobito važno u svjetlu pretpostavke da je pojam Istria i za autora AG-a mogao označavati znatno veći prostor od jadranskoga poluotoka. Nakon ukazivanja na čitav niz "srodnih deformacija” u prikazima jadransko-istočnoalpsko-panonskoga prostora nameće se i pitanje o mogućoj vezi između prikazanih (mahom engleskih!) zemljovida i razmotrene vizije geografa iz kruga engleskoga kralja Alfreda Velikog. Naime, razmatranje odabranih zemljovida i njihove slike prostora dovodi konačno i do potrebe sučeljavanja “lebdeće i neodređene” Istre koja se, kao što je pokazano, pojavljivala kod raznih geografa, s jedne strane, i “činjenične” Istre jasno određene i dobro opisane u mnogim vrelima, s druge strane. Jedno od prvih pitanja koja se u tome kontekstu nameću jest: jesu li Alfredovi suvremenici i nasljednici koji su nekritički prenosili geografsko znanje prethodnih stoljeća bili svjesni nerealnosti svojih zemljopisnih vizija? Ili, je li moguće pretpostaviti da su određene stvarne okolnosti utjecale na njihovu geografsku percepciju? Dosadašnja rasprava pokazala je da su srednjovjekovni geografi i kartografi često baštinili i reproducirali iskrivljenu sliku stvarnosti uvelike oblikovanu na arhaičnim kontaminacijama. Međutim, time je pitanje odnosa klasične geografije i stvarnih zemljopisnih odnosa u vrijeme sastavljanja AG-a tek dotaknuto. Drugim riječima, pitanje odnosa različitih Geografija i granica poznatih iz pouzdanijih izvora moguće je postaviti u obliku dva potpitanja. Ponajprije, je li geografska percepcija Istre kao prostora koji se proteže od sjevernoga Jadrana do duboko u unutrašnjost njegova kopnenoga zaleđa u ikojem povijesnom odsječku imala uporište u stvarnosti? I, s druge strane, je li uočena “iskrivljena geografska percepcija” mogla u određenom kontekstu "povratno" utjecati na shvaćanje i oblikovanje administrativnoga prostora Istre? Možda se može učiniti da je na oba pitanja vrlo lako odgovoriti 
niječno, međutim, složenost problema koji se naziru pri njihovom postavljanju nalaže nam ostaviti ih zasad otvorenima.

Dosad iznesena opažanja mogu se svesti na sljedeće: čini se da autor Alfredove geografije spominjući Istru ne govori, usprkos određenim nejasnoćama, o Dunavu. Međutim, njegova prilično precizna slika razmatranoga prostora daje naslutiti da njegovo shvaćanje prostora Istre nije podudarno ni sa suvremenim određenjem Istre kao sjevernojadranskoga poluotoka. Ovi i drugi navedeni zaključci počivaju na argumentima izvedenima na temelju raščlambe tri skupine izvora. Tu su, prije svega, djela antičkih geografa (bilo u izvornom, bilo u kakvom tradiranom, makar i skraćenom ili iskrivljenom obliku), koja su (ako su bila poznata i dostupna) uvijek bila, osobito ako se radi o uglednijim i čitanijim auctoritates, mogući predlošci srednjovjekovnim geografima. Tu je, zatim, i čitav niz kasnoantičkih i ranosrednjovjekovnih izvora koji, iako ne nužno i direktan izvor autoru AG-a, odražavaju proširena shvaćanja određenih pojmova te kao takvi čine referentan okvir za razumijevanje i tumačenje njegove zemljopisne vizije. Konačno, najstarija srednjovjekovna kartografija u obliku brojnih mappae mundi-uvelike poput “iskrivljujućega ogledala” podsjećajući na "tvrdoglavo” preživljavanje starijih pogrešaka (koje ipak nisu nužno i uvijek nenamjerne) - predstavlja moguću polaznu točku za retrospektivno razumijevanje AG-a.

U tom kontekstu, pretpostavka da je autor AG-a imao na umu Istru koja za njega, u najmanju ruku, nije tek jadranski poluotok te pretpostavka da ju je na neki način zaista želio povezati s Dunavom (što još ne smatram nužno dokazanim), čini znatno vjerojatnijim da je na umu mogao imati i “južni dunavski krak”, tj. nejasno određen prostor koji se proteže od sjevernoga Jadrana kroz prostor Alpa prema međurječju Save i Drave nego da je mislio na središnje Podunavlje. Povijest nije doduše zabilježila postojanje tvorbe koja bi pod istarskim imenom obuhvatila to područje, no nije neutemeljeno pretpostaviti da su, među ostalim, i “milenijske zabune” odigrale određenu ulogu u oblikovanju percepcije toga dijela oboda Karolinškoga Carstva. ${ }^{245}$

245 U tom kontekstu želim osobito zahvaliti kolegi Ivanu Basiću, čije su me opsežne i opravdane primjedbe ponukale da dio materijala, argumenata i zaključaka izostavim iz ovoga teksta i priredim kao zaseban rad. 
Takvo domišljanje ne implicira, dakako, da bi razmotrena vrela upućivala na to da su se administrativne granice kasnoantičke ili ranosrednjovjekovne Istre zaista protezale preko Alpa duboko na istok u Panoniju ili pak da je na prostoru istočnih Alpa postojala kakva administrativna cjelina pod istarskim imenom. Međutim, kao što je ovdje izloženo, čitav niz izvora nastalih u vrlo širokom vremenskom luku svjedoči o neprekinutoj kontaminaciji geografske percepcije pojma Istria s jednim od imena za rijeku Dunav i njezinom preživljavanju sve do u visoki srednji vijek. Na tragu toga opažanja nalazim dopuštenim pretpostaviti da su i ranosrednjovjekovni autori, oslanjajući se na "geografsko znanje" prethodnih generacija, mogli i nejasno određen prostor sjeverno i istočno od granica istarskoga poluotoka na neki način smatrati dijelom Istre. ${ }^{246}$ Važno je, doduše, naglasiti da je ta vrsta kontaminacije karakteristična uglavnom za izvore nastale izvan toga prostora, i to često one koji i inače nekritički prenose starije podatke iz antičkih izvora. Stoga, imajući u vidu iznesena opažanja, uočene veze Istre i Istra ipak valja smjestiti ponajprije u Illyricum mythologicum, tj. u sferu simboličke, umnogome "nestvarne geografije", prije no u okvire kakve ranosrednjovjekovne političke ili administrativne stvarnosti. Pa ipak, postojanje očitih "etimoloških" i prostornih podudarnosti, asocijacija u književnim i drugim pisanim predlošcima dopušta barem domišljanje o njihovoj mogućoj ranosrednjovjekovnoj uporabi. U tome smislu vjerujem da ne bi trebalo isključiti mogućnost da su upravo neke od uočenih veza i "projekcija" tijekom ranoga srednjeg vijeka mogle naći svoje mjesto i u kontekstu nekoga od različitih oblika uporaba znanja o prošlosti i zemljopisu. Stoga u daljnjem proučavanju i promišljanju ovdje razmotrene problematike ne bi trebalo isključiti ni mogućnost da je poneki ranosrednjovjekovni autor, pa i autor Alfredove geografije, u tehničkom smislu možda zaista reproducirajući stare antičke zablude, pred očima mogao imati videnje prostora Istre i Dalmacije nešto drugačije od onoga na koje smo danas navikli.

246 Vjerojatno najočitiji primjer toga jest popis biskupa gradeške patrijaršije koji se na saboru u Rimu

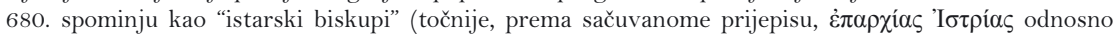
prouinciae Istriae). Među potpisanima su biskupi s područja Venecije (Aquileia, Opitergium, Patavium i

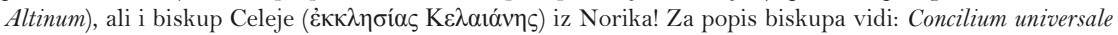
Constantinopolitanum tertium, ACO II, 2/1, ed. Rudolf Riedinger, Berlin 1990., 154-155, te o toj temi opširnije: Rajko Bratož, "Das Patriarchat Grado im monotheletischen Streit”, u: Slovenija in sosednje dežele med antiko in karolinško dobo. Začetki slovenske etnogeneze / Slowenien und die Nachbarländer zwischen Antike und karolingischer Epoche. Anfänge der slowenischen Ethnogenese, vol. II, ur. Rajko Bratož, Ljubljana 2000., 609-658. O takvoj percepciji Istre vidi i: Andrej Novak, L'Istria nella prima età bizantina, Collana degli atti 27, Rovigno 2007., 19-20, 22. 


\section{Sažetak}

Autor se pridružuje raspravi o mogućim značenjima pojma Histria u takozvanom Staroengleskom Oroziju ili Zemljopisu Alfreda Velikog. Krenuvši od nedavno objavljene (1999.) teze Mirjane Matijević Sokol i Vladimira Sokola koji su značenje pojma interpretirali kao Dunav, autor analizira njihove argumente i pronalazi ih inspirirajućima. Naime, osvrćući se na problem isticanjem važnosti Zemljopisa za hrvatsku ranosrednjovjekovnu povijest, spomenuti su autori zaključili da ako je Histria značila Dunav, tada se Dalmatia, koju su oni interpretirali kao Hrvatska, morala prostirati sve do srednjega Dunava krajem 9. stoljeća. Autor smatra da je njihova najveća zasluga u naglašavanju važnosti razumijevanja "tisućljetnih zabluda" klasičnih autora koji su zamjenjivali Dunav za Istru i u čijem kontekstu je raspad klasične zemljopisne paradigme mogao igrati značajnu ulogu u stvaranju ranosrednjovjekovnoga znanja o regiji. Njihove je zaključke o identitetu Histrije i Dalmacije u Alfredovom tekstu ipak ispravno kritizirao Radoslav Katičić (2003.), koji se uvjerljivo usprotivio shvaćanju pojma Histria kao Dunava, preferirajući tradicionalnu interpretaciju.

Autor ovog teksta u obzir je uzeo argumente tih autora i pokušao se odmaknuti pažljivo proučivši prethodno spomenuta "zamjenjivanja" uzimajući u obzir velik broj klasičnih, kasnoantičkih i ranosrednjovjekovnih literarnih i kartografskih tekstova te pokušavajući pronaći moguće izvore i doslovan kontekst Alfredovog viđenja regije. Izbjegavajući pratiti dva predložena pravca, autor je, u svjetlu analiziranih pisanih izvora i zemljovida datiranih između 5. st. pr. Kr. i 13. st. n. e., istražio mogućnost da je pojam Histria u Alfredovu djelu - kao i u širem kasnoantičko-ranosrednjovjekovnom kontekstu - mogao, osim jadranskoga poluotoka, obuhvaćati i šire zaleđe. lako je iznimno teško točno odrediti značenje takve "veće Istre", autor utvrđuje različitu upotrebu pojma čime se osvjedočuje u postojanje "oblika znanja", koji smatra da se Istra prostirala duboko prema onome što je danas Slovenija, to jest, da pojam obuhvaća dijelove rimskih provincija Venecije i Istre te Norika. Predlažući tumačenje da je ova kasnoantičko-ranosrednjovjekovna upotreba pojma mogla zaista potjecati iz "antičkih zamjena" (često u obliku "mitskih preživljavanja"), autor ukazuje na moguće političke, pa čak i administrativne kontekste u kojima je Istra mogla značiti "nešto više od samo jadranskoga poluotoka". Uzimajući u obzir složenost problema, autor se ipak suzdržava od pokušavanja davanja odgovora na pitanje kada se takva upotreba pojavila i u kojem je točno kontekstu mogla funkcionirati, ostavljajući ove odgovore nekoj drugoj, detaljnijoj i usredotočenijoj analizi.

\section{Histria e Hister dei geografi tardoantichi e altomedievali: contributo alla discu- ssione dell'accenno all'Istria e alla Dalmazia nella Geografia di Alfredo il Grande Riassunto}

L'autore aderisce alla discussione sui possibili significati del termine Histria, presente nel cosiddetto Orosio anglosassone o Geografia di Alfredo il Grande. Partendo dalla tesi di Mirjana Matijević Sokol e Vladimir Sokol pubblicata recentemente (1999), che vede tale termine interpretato come Danubio, l'autore analizza i loro argomenti trovandoli ispirativi. Infatti, se il problema si osserva accentuando l'importanza della Geografia per la storia altomedioevale croata, gli autori sono arri- 
vati alla conclusione che, se il significato di Histria fosse stato quello di Danubio, allora la Dalmatia, interpretata da loro come Croazia, alla fine del IX secolo avrebbe dovuto estendersi fino alla zona del medio Danubio. L'autore ritiene che il loro maggior merito è quello di aver enfatizzato l'importanza della comprensione degli "equivoci millenari" degli autori classici che confondevano il Danubio con l'Istria e nel cui contesto il disfacimento del paradigma geografico classico ha potuto giocare un ruolo significativo nella conoscenza altomedievale della regione. Le loro conclusioni sull'identità della Histria e della Dalmatia nel testo di Alfredo il Grande sono state correttamente criticate da Radoslav Katičić (2003), che ha contrastato in maniera convincente l'interpretazione del termine Histria come Danubio, preferendo l'interpretazione tradizionale.

L'autore di questo testo ha preso in considerazione gli argomenti di tali autori e ha cercato di distanziarsi, osservando attentamente le sopramenzionate "sostituzioni", prendendo in considerazione un vasto numero di testi letterari e cartografici classici, tardoantichi ed altomedievali e tentando di trovare delle possibili fonti e il contesto letterale della visione che Alfredo il Grande aveva avuto della regione. Evitando di seguire le due direzioni proposte, l'autore, alla luce delle fonti scritte e delle carte geografiche datate tra il V secolo a.C. ed il XIII secolo d.C. da lui analizzate, ha considerato la possibilità che il termine Histria nell'opera di Alfredo il Grande - così come in un contesto tardoantico-altomedievale più vasto - avesse potuto comprendere, accanto alla penisola adriatica, anche un entroterra più ampio. Anche se è molto arduo definire il significato di tale "Istria più ampia", l'autore afferma un uso variegato di tale termine, il che testimonia l'esistenza di una "forma di sapere" che reputa che l'Istria si estendesse considerevolmente entro quei territori che oggi costituiscono la Slovenia, ovvero, che il termine comprendesse territori delle provincie romane di Venezia ed Istria e del Norico. Proponendo l'interpretazione in cui l'uso tardoantico-altomedievale del termine sarebbe realmente potuto provenire dagli "equivoci antichi" (spesso nella forma di "sopravvivenze mitiche"), l'autore indica i possibili contesti politici, e perfino amministrativi, in cui Istria poteva significare "qualcosa in più della sola penisola". Prendendo in considerazione la complessità del problema, l'autore si trattiene dal tentativo di offrire delle risposte alla domanda quando sarebbe apparso tale uso e in quale contesto concreto avrebbe potuto sussistere, lasciando queste risposte ad una futura analisi, ulteriormente mirata e dettagliata.

\section{Histria and Hister in Late Antique and Early Medieval authors: contribution to the discussion on the mention of Istria and Dalmatia in the Geography of Alfred the Great}

\section{Summary}

In this paper author joins the discussion on the possible meanings of the terms Histria in the so called Old English Orosius or Geography of Alfred the Great. Departing from recently (1999) published hypothesis of Mirjana Matijević Sokol and Vladimir Sokol, who interpreted the term as meaning the Danube, the author analyses their arguments finding them highly inspirational. Namely, addressing the issue by 
pointing out to the relevance of the Geography for the history of early medieval Croatia history, they concluded that if Histria stood for the Danube, then Dalmatia, which they interpreted as meaning Croatia, must have spread as far as Middle Danube at the end of the 9th century. In the author's opinion, their greatest merit lays in their emphasis on the importance of understanding "millennial confusions" of the Classical authors who contaminated Istria with Danube and which in the context of the dissolution of the Classical geographical paradigm might have played an important role in formation of early medieval geographical knowledge of the region. However, their conclusions about the identity of Histria and Dalmatia in Alfred's text were justly criticised by Radoslav Katičić (2003) who convincingly argued against understanding the term Histria as Danube, preferring the traditional interpretation.

The author of the present paper, taking into consideration the arguments raised by these authors, tries to move further by cautiously examining the aforementioned "contaminations" that is taking into consideration a large number of Classical, late antique and early medieval literary and cartographic texts in an attempt to trace the possible sources and literal context of Alfred's vision of the region. Avoiding to follow the two suggested paths, the author, in the light of the analysed sources and maps dated between 5 th $c . B C$ and 13 th century AD, explores the possibility that Histria in Alfred's work - as well as in the broader late antiqueearly medieval context, might have, beside Adriatic peninsula, meant its broader hinterland. Although it is extremely hard to pinpoint the exact meaning of such "large Istria", the author traces diverse usages of the term which seem to testify to the existence of the "form of knowledge" which considers Istria stretching deep in the what is nowadays Slovenia, that is covering parts of Roman provinces of Venetia et Histria and Noricum. Suggesting that this peculiar late antique-early medieval usage of the term, might have indeed originated in "ancient contaminations" (often in the form of "mythological survivals"), the author indicates possible political and even administrative context in which Istria might have come to mean "something more than simply Adriatic peninsula". However, taking into the consideration the complexity of the issue, the author refrains from an attempt to provide a positive answer to the question of when such usage appeared and in what exact contexts it might have functioned, leaving these questions for another, more thorough and focused analysis. 